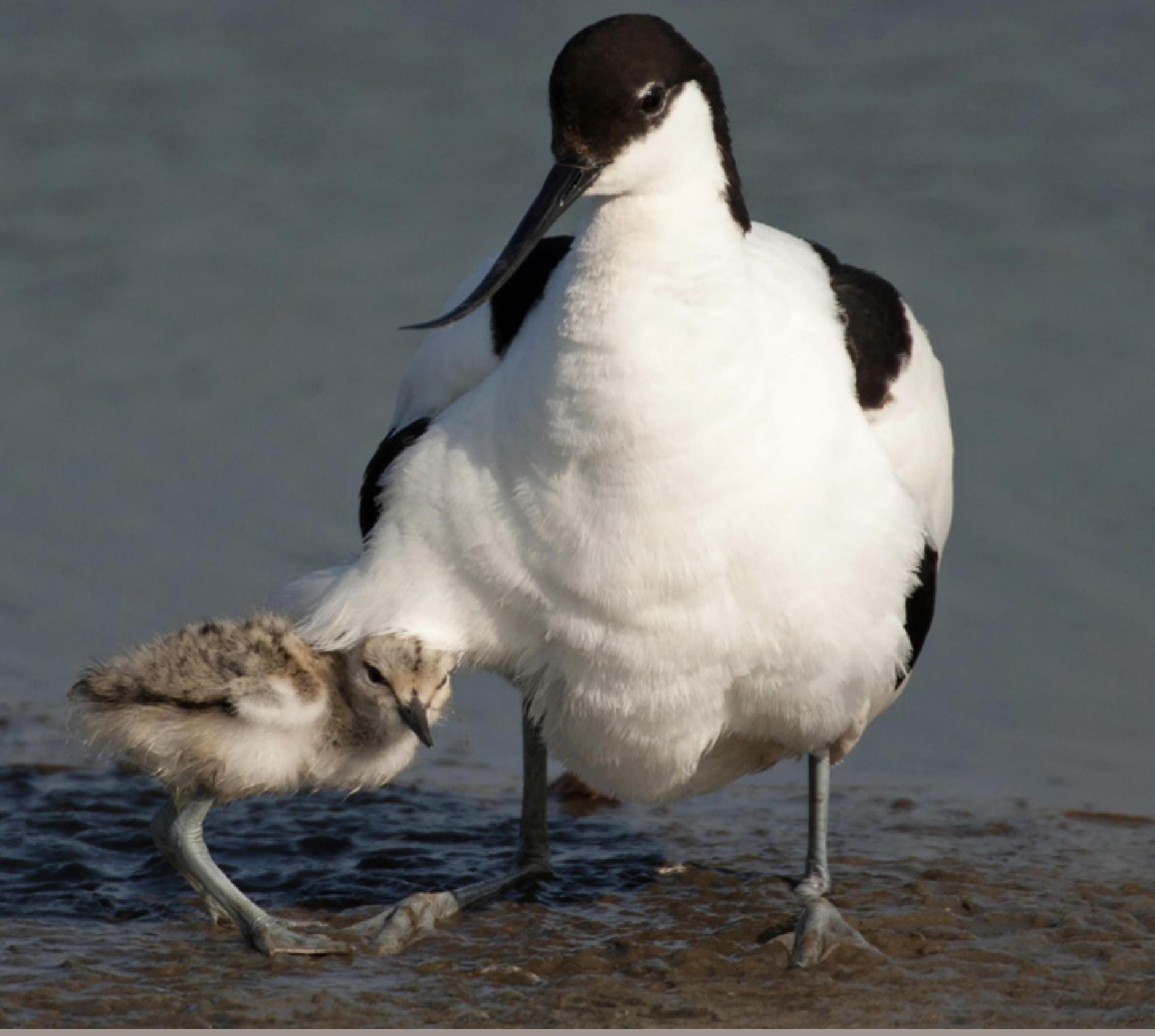

Broedsucces van kustbroedvogels in de Waddenzee

Resultaten 2015-2016 en trends in broedsucces in 2005-2016

K. Koffijberg, J.S.M. Cremer, P. de Boer, J. Nienhuis, H. Schekkerman,

K. Oosterbeek \& J. Postma

| WOt-technical report 112 Sovon-rapport 2017/66 WMR-rapport C100/17 

Broedsucces van kustbroedvogels in de Waddenzee 
Dit Technical report is gemaakt conform het Kwaliteitsmanagementsysteem (KMS) van de unit Wettelijke Onderzoekstaken Natuur \& Milieu, onderdeel van Wageningen University \& Research.

De WOT Natuur \& Milieu voert wettelijke onderzoekstaken uit op het beleidsterrein natuur en milieu. Deze taken worden uitgevoerd om een wettelijke verantwoordelijkheid van de Minister van Landbouw, Natuur en Voedselkwaliteit (LNV) te ondersteunen. De WOT Natuur \& Milieu werkt aan producten van het Planbureau voor de Leefomgeving, zoals de Balans van de Leefomgeving en de Natuurverkenning. Verder brengen we voor het ministerie van LNV adviezen uit over (toelating van) meststoffen en bestrijdingsmiddelen, en zorgen we voor informatie voor Europese rapportageverplichtingen over biodiversiteit.

De reeks 'WOt-technical reports' bevat onderzoeksresultaten van projecten die kennisorganisaties voor de unit Wettelijke Onderzoekstaken Natuur \& Milieu hebben uitgevoerd.

WOt-technical report 112 is het resultaat van een onderzoeksopdracht van en gefinancierd door het ministerie van Landbouw, Natuur en Voedselkwaliteit. 


\section{Broedsucces van kustbroedvogels in de Waddenzee}

Resultaten 2015-2016 en trends in broedsucces in 2005-2016

K. Koffijberg, J.S.M. Cremer, P. de Boer, J. Nienhuis, H. Schekkerman, K. Oosterbeek \& J. Postma

Wettelijke Onderzoekstaken Natuur \& Milieu

Wageningen, december 2017

WOt-technical report 112

Sovon-rapport 2017/66

WMR-rapport C100/17

ISSN 2352-2739

DOI: $10.18174 / 428641$ 


\section{Referaat}

Koffijberg K., J.S.M. Cremer, P. de Boer, J. Nienhuis, H. Schekkerman, K. Oosterbeek \& J. Postma (2017). Broedsucces van kustbroedvogels in de Waddenzee. Resultaten 2015-2016 en trends in broedsucces in 2005-2016. WOt-technical report 112; Sovon-rapport 2017/66; Wageningen Marine Research-rapport C100/17. WOT Natuur \& Milieu, WUR, Wageningen / Sovon Vogelonderzoek Nederland, Nijmegen / Wageningen Marine Research, Den Helder. 50 blz.; 29 fig.; 10 tab.; 35 refs.

Sinds 2005 worden in de Waddenzee jaarlijks gegevens verzameld over het broedsucces van een aantal karakteristieke kustbroedvogels. Hiervoor worden tien vogelsoorten gevolgd die representatief worden geacht voor specifieke habitats en voedselgroepen. Het reproductiemeetnet kustbroedvogels wordt uitgevoerd als een 'early warning systeem' om het reproducerend vermogen van de vogelpopulaties in de Waddenzee te volgen en de achterliggende processen van populatieveranderingen te doorgronden. Het fungeert als een belangrijke aanvulling op de monitoring van aantallen en aantalsveranderingen en wordt uitgevoerd in het kader van trilaterale afspraken met Duitsland en Denemarken (TMAP). Uit de resultaten van 2015-2016 en analyse van gegevensreeksen uit de periode 2005-2016 (soms langer) blijkt dat een aantal soorten in veel jaren en gemiddeld genomen weinig jongen grootbrengen. Dit geldt vooral voor Scholekster, Kluut, Visdief en Noordse Stern, en in de afgelopen jaren ook voor Kokmeeuw, waarvan het broedsucces sinds 1995 significant is afgenomen. Andere soorten met een significant afnemend broedsucces zijn Lepelaar en Visdief. Alleen bij Kleine Mantelmeeuw was sinds 2005 sprake van een significante verbetering van het broedsucces.

Trefwoorden: broedsucces, Waddenzee, Trilaterale monitoring, TMAP, Lepelaar, Eider, Scholekster, Kluut, Kokmeeuw, Kleine Mantelmeeuw, Zilvermeeuw, Grote Stern, Visdief, Noordse Stern

\section{Abstract}

Koffijberg K., J.S.M. Cremer, P. de Boer, J. Nienhuis, H. Schekkerman, K. Oosterbeek \& J. Postma (2017). Breeding success of coastal breeding birds in the Wadden Sea. Results in 2015-2016 and trends in breeding success in 20052016. Statutory Research Tasks Unit for Nature and the Environment (WOT Natuur \& Milieu) Wageningen. WOttechnical report 112. 50 p; 29 figs; 10 tabs; 35 refs.

Data have been collected on the breeding success of several characteristic coastal breeding birds in the Wadden Sea each year since 2005. Ten birds species considered representative of specific habitats and food groups are being monitored. The monitoring scheme on breeding success in coastal breeding birds is run as an 'early warning system' to follow the reproductive capacity of the bird populations in the Wadden Sea and understand the processes underlying fluctuations in populations. It is a valuable addition to the monitoring of population numbers and is carried out under a trilateral agreement with Germany and Denmark (TMAP). The results from 2015-2016 and an analysis of data series from the period 2005-2016 (sometimes longer) show that several species on average reared too few young to sustain stable population size in many of these years, especially the Eurasian Oystercatcher, Pied Avocet, Common Tern and Arctic Tern, and in recent years also the Black-headed Gull, whose breeding success has significantly declined since 1995. Other species showing a significant decline in breeding success are the Spoonbill and Common Tern. The only species to show any significant improvement in breeding success since 2005 is the Lesser Black-backed Gull.

Keywords: breeding success, Wadden Sea, trilateral monitoring, TMAP, Eurasian Spoonbill, Common Eider, Eurasian Oystercatcher, Pied Avocet, Black-headed Gull, Herring Gull, Lesser Black-backed Gull, Sandwich Tern, Common Tern, Arctic Tern

Foto omslag: Harvey van Diek, Sovon

Auteurs: Kees Koffijberg (Sovon Vogelonderzoek Nederland), Jenny Cremer (Wageningen Marine Research), Peter de Boer, Jeroen Nienhuis, Hans Schekkerman, Kees Oosterbeek \& Jelle Postma (allen Sovon Vogelonderzoek Nederland)

\section{(C) 2017 SOVON Vogelonderzoek Nederland}

Postbus 6521, 6503 GA Nijmegen

Tel. (024) 7410 410; e-mail:

kees.koffijberg@sovon.nl; www.sovon.n

\section{Wageningen Marine Research}

Postbus 57, 1780 AB Den Helder

Tel. (0317) 480 900; e-mail: jenny.cremer@wur.nl

De reeks WOt-technical reports is een uitgave van de unit Wettelijke Onderzoekstaken Natuur \& Milieu, onderdeel van Wageningen University \& Research. Dit technical report is verkrijgbaar bij het secretariaat. De publicatie is ook te downloaden via www.wur.nl/wotnatuurenmilieu.

Wettelijke Onderzoekstaken Natuur \& Milieu, Postbus 47, 6700 AA Wageningen Tel: (0317) 4854 71; e-mail: info.wnm@wur.nl; Internet: www.wur.nl/wotnatuurenmilieu.

Alle rechten voorbehouden. Niets uit deze uitgave mag worden verveelvoudigd en/of openbaar gemaakt door middel van druk, fotokopie, microfilm of op welke andere wijze ook zonder voorafgaande schriftelijke toestemming van de uitgever. De uitgever aanvaardt geen aansprakelijkheid voor eventuele schade voortvloeiend uit het gebruik van de resultaten van dit onderzoek of de toepassing van de adviezen. 


\section{Woord vooraf}

In de voorliggende WOt-publicatie worden de resultaten en trends van het reproductiemeetnet kustbroedvogels in 2015 en 2016 gepresenteerd. Doel is om de verzamelde gegevens te presenteren en toegankelijk te maken voor breder gebruik. Het project 'Reproductiemeetnet Kustbroedvogels' wordt uitgevoerd in het kader van de wettelijke onderzoekstaken binnen het thema Informatievoorziening Natuur, gecoördineerd door het ministerie van Landbouw, Natuur en Voedselkwaliteit, en is onderdeel van het trilaterale monitoring programma (TMAP). Het hiervoor benodigde veldwerk wordt gecoördineerd door Sovon Vogelonderzoek Nederland, in samenwerking met Wageningen Marine Research. Het onderzoek zou zonder de inzet van veel vrijwilligers van Sovon niet kunnen worden uitgevoerd.

Kees Koffijberg

Jenny Cremer

Peter de Boer

Jeroen Nienhuis

Hans Schekkerman

Kees Oosterbeek

Jelle Postma 



\section{Inhoud}

Woord vooraf

Summary

$1 \quad$ Inleiding

2 Methode en materiaal

2.1 Opzet van het Meetnet Reproductie in de Waddenzee $\quad 15$

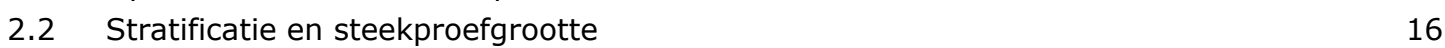

$\begin{array}{ll}2.3 & \text { Uitvoering veldwerk in 2015-2016 }\end{array}$

2.4 Verwerking van gegevens 19

$\begin{array}{ll}2.5 \text { Analyses } & 19\end{array}$

3 Weersomstandigheden in voorjaar 2015 en $2016 \quad 21$

3.1 Weersomstandigheden en waterstanden in $2015 \quad 21$

3.2 Weersomstandigheden en waterstanden in $2016 \quad 22$

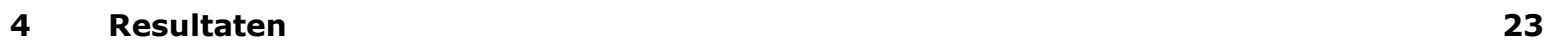

$\begin{array}{lll}4.1 & \text { Algemeen } & 23\end{array}$

4.2 Lepelaar Platalea leucorodia - Eurasian Spoonbill 23

4.3 Eider Somateria mollissima - Common Eider $\quad 25$

4.4 Scholekster Haematopus ostralegus - Eurasian Oystercatcher 27

$\begin{array}{lll}4.5 & \text { Kluut Recurvirostra avosetta - Pied Avocet } & 28\end{array}$

4.6 Kokmeeuw Chroicocephalus ridibundus - Black-headed Gull 30

4.7 Kleine Mantelmeeuw Larus fuscus - Lesser Black-backed Gull 32

4.8 Zilvermeeuw Larus argentatus - Herring Gull $\quad 34$

4.9 Grote Stern Sterna sandvicensis - Sandwich Tern 36

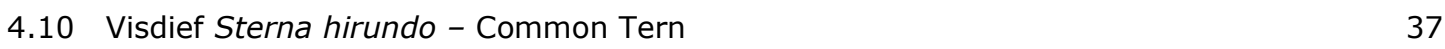

4.11 Noordse Stern Sterna paradisaea - Arctic Tern 39

$5 \quad$ Conclusies en discussie $\quad 43$

$\begin{array}{lr}\text { Literatuur } & 45\end{array}$

$\begin{array}{lr}\text { Verantwoording en dankwoord } & 47\end{array}$ 



\section{Samenvatting}

Sinds 2005 worden in de Waddenzee jaarlijks gegevens verzameld over het broedsucces van een aantal karakteristieke kustbroedvogels. Dit Meetnet Reproductie in de Waddenzee wordt uitgevoerd als een early warning systeem om het reproducerend vermogen van de vogelpopulaties in de Waddenzee te volgen en de achterliggende processen van populatieveranderingen te doorgronden. Het vormt daarmee een belangrijke aanvulling op de sinds 1990 lopende monitoring van aantallen broedvogels, die vanuit het Nederlandse Netwerk Ecologische Monitoring en het trilaterale monitoring programma TMAP wordt georganiseerd. Het Meetnet Reproductie is onderdeel van het WOT-IN (Wettelijke Onderzoekstaken Informatievoorziening Natuur) en wordt gecoördineerd door Sovon Vogelonderzoek Nederland in samenwerking met Wageningen Marine Research (voorheen IMARES). Sinds 2009-2010 is het tevens opgenomen in TMAP (parameter 'breeding success'). Verder worden de gegevens sinds 2014 verwerkt in de OSPAR-biodiversiteitsindicator 'B3 breeding success', die voor de evaluatie van de Kaderrichtlijn Mariene Strategie wordt gebruikt.

In totaal worden in het reproductiemeetnet in de internationale Waddenzee tien soorten vogels gevolgd die representatief worden geacht voor specifieke habitats en voedselgroepen: Lepelaar, Scholekster, Kluut, Kleine Mantelmeeuw, Zilvermeeuw, Kokmeeuw, Eider, Grote Stern, Noordse Stern en Visdief. Van deze tien soorten worden in de Nederlandse Waddenzee jaarlijks op ongeveer 65 locaties gegevens verzameld over het broedsucces. In deze rapportage worden de resultaten van 2015 en 2016 gepresenteerd en wordt een overzicht van ontwikkelingen sinds de start van het meetnet in 2005 gegeven (voor sommige soorten, indien gegevens beschikbaar, ook langer). Belangrijkste doel van de rapportage is het presenteren van de basale resultaten en het signaleren van trends.

Van de tien soorten waarvan het broedsucces wordt gevolgd nam het aantal broedparen sinds 1990 bij zeven soorten af. Bij vier van deze soorten blijkt het broedsucces zeker onvoldoende om de broedvogelaantallen op peil te houden. Het gaat om Scholekster, Kluut, Visdief en Noordse Stern. Bij Kluut en Visdief nam het aantal broedparen ook sterker af dan elders. Zowel bij Kluut als Noordse Stern liggen het aantal broedparen op een niveau (ver) beneden de geformuleerde instandhoudingsdoelen in het Natura 2000-beheerplan Waddenzee. Bij Scholekster is sprake van een 'stabiel' laag broedsucces, bij de andere drie soorten fluctueert het broedsucces van jaar op jaar op een laag niveau, zonder duidelijke trend. Kluut deed het in 2015 en 2016 wat beter dan in voorgaande jaren, maar bracht ook in deze twee jaren te weinig jongen groot.

Bij de andere zes soorten wisselen goede en slechte jaren elkaar af, of verschilt het broedsucces binnen de Waddenzee. Alleen bij Lepelaar en Kokmeeuw is sprake van een significant negatieve trend in broedsucces. De Kokmeeuw bracht na 2010 te weinig jongen groot en behoort met de vier bovengenoemde soorten thuis in het rijtje soorten dat zowel slechte broedresultaten als een afname in aantallen broedparen laat zien. De Lepelaar is een speciaal geval: het aantal broedparen in de Waddenzee groeide in de afgelopen decennia spectaculair, maar het afnemende broedsucces wijst er op dat de capaciteit van het gebied voor de soort in zicht is, wat ook wordt bevestigd door het lepelaaronderzoek voor het Metawad-project. Een ander speciaal geval is de Kleine Mantelmeeuw. Van deze soort stabiliseerde de broedpopulatie, na een eerdere toename. Het broedsucces was in de eerste jaren van het Meetnet Reproductie laag, maar nam in de afgelopen jaren significant toe en ligt in sommige jaren ook binnen de bandbreedte van broedsucces dat voldoende wordt geacht voor het behoud van de populatie.

Deze resultaten bevestigen de eerdere review van de populatiedemografie van vogels in de Waddenzee (Van der Jeugd et al. 2014), waarin werd geconcludeerd dat bij de meeste soorten het (gebrek aan) broedsucces een belangrijke drijfveer was achter de waargenomen (negatieve) populatieveranderingen, ook als die worden bekeken in de context van de andere belangrijke demografische parameter, de jaarlijkse overleving. De oorzaken van de slechte broedresultaten zijn divers, en kunnen ook onderling samenhangen. Belangrijke factoren die uit de resultaten van de 
broedsuccesmetingen naar voren komen zijn predatie (vooral op de kwelders langs het vasteland), verliezen aan legsels door hoge waterstanden als gevolg van zomerstormen (zowel vasteland als eilanden) en voedselproblemen. Vooral dat laatste aspect is echter met alleen monitoringgegevens moeilijk te onderbouwen, en ook moeilijker aan te tonen dan predatie en verliezen door zomerstormen. Het feit dat het nestsucces van een aantal kolonievogels (en ook Kluut, indien kolonies worden beschermd door een elektrisch raster tegen predatie) goed is, maar uiteindelijk toch te weinig jongen worden grootgebracht is een aanwijzing dat de hoeveelheid voedsel in de kuikenperiode een beperkende factor zou kunnen zijn. 


\section{Summary}

Since 2005 the breeding success of a number of coastal breeding birds has been monitored in the Dutch Wadden Sea. Initially, mainly shellfish-eating birds were surveyed, but with the inclusion of breeding success as a parameter within the trilateral TMAP monitoring programme run by the three Wadden Sea countries (the Netherlands, Germany and Denmark) in 2009-10, ten selected species are currently being monitored: Eurasian Spoonbill, Common Eider, Eurasian Oystercatcher, Pied Avocet, Black-headed Gull, Herring Gull, Lesser Black-backed Gull, Sandwich Tern, Common Tern and Arctic Tern. Data are collected both during the nesting phase to determine nest success (except Sandwich Tern and Eurasian Spoonbill) and during the chick-rearing phase to determine breeding success (all species). The main aim is to determine breeding success in terms of the number of fledged chicks per pair. Data collection is carried out at about 65 sites/colonies within the Dutch Wadden Sea area. This report presents results for 2015-16. It gives an overview of trends in breeding success observed during 2005-2016 (with longer data series for some species) and consists mainly of analyses of the ten species monitored. The main aim is to present baseline results and make data accessible for further analyses and comparisons. Long-term data are tabulated for nest success (either Mayfield or apparent nest success) and trends in the number of fledged young per pair. Trends in numbers are also presented, with separate series for the western Wadden Sea, eastern Wadden Sea and the EmsDollard estuary.

In seven of the ten species the numbers of breeding pairs has declined since 1990. In four of these species, Eurasian Oystercatcher, Pied Avocet, Common Tern and Arctic Tern, breeding success is below the minimum values considered necessary to support a stable population. The rates of decline in the populations of Pied Avocet and Common Tern have been higher than in other regions (e.g. the Dutch Delta area and other parts of the international Wadden Sea). In Pied Avocet and Arctic Tern, the present numbers of breeding pairs are well below the conservation objectives set for the Natura 2000 site 'Wadden Sea'. In Eurasian Oystercatcher, breeding success has remained stable since 2006 albeit at a low level. The breeding success rates of the other three species vary from year to year and show no significant trend. The Pied Avocet achieved higher reproduction rates in 2015 and 2016, but these are still insufficient to support at least a stable population.

The breeding success of the six other species in the Wadden Sea varies, alternating between good and poor years. Only the Eurasian Spoonbill and Black-headed Gull showed a significant decline in breeding success. The Black-headed Gull has had a poor reproductive output since 2010 and therefore joins the group of four species mentioned earlier that show both poor breeding results and a significant decline in breeding numbers. The Eurasian Spoonbill is a special case. It has experienced an ongoing increase in numbers in the past decades, but given the saturated growth level in breeding pairs and the significant decline in breeding success, the species seems to face density-dependence, which is also confirmed by ongoing species-specific research. Another specific case is the Lesser Blackbacked Gull, which has undergone a long-term increase in the size of the population, but this has also stabilised. Its breeding success was poor in the initial years of the monitoring scheme, but has increased significantly since then (in contrast to the Herring Gull).

The results of the breeding success monitoring scheme support the demographic review made in 2014, which included annual survival rates (Van der Jeugd et al. 2014). This review concluded that in many coastal breeding birds in the Wadden Sea, poor breeding success is the most important driver for the observed negative population changes. The causes of poor breeding success are numerous, but the most significant causes of breeding failure observed so far are a high risk of predation (especially along the mainland coast), loss of clutches or chicks due to flooding after summer storms (both mainland and islands) and food limitations. However, food limitations are difficult to estimate from data on breeding success data alone. In colony-breeding birds in particular, adequate nest success is often counterbalanced by poor chick survival and low numbers of fledged chicks, which may suggest that food provisioning is an important constraint. Even when colonies of Pied Avocet are protected by electrical fences to protect them for mammalian predators, the final breeding success is still low. 


\section{$1 \quad$ Inleiding}

Aanvullend op de monitoring van aantallen en verspreiding van kustbroedvogels (Koffijberg et al. 2015a, Boele et al. 2016) worden in de Nederlandse Waddenzee sinds 2004-2005 (soms al langer) gegevens verzameld over het broedsucces. Deze monitoring van broedsucces vindt plaats voor de Wettelijke Onderzoekstaken thema Informatievoorziening Natuur (WOT-IN) en (sinds 2010) voor het trilaterale TMAP-programma ${ }^{1}$ (Thorup \& Koffijberg 2015). Sinds 2014 worden de resultaten verder gebruikt bij de biodiversiteitsindicatoren voor de Kaderrichtlijn Mariene Strategie, uitgevoerd naar de systematiek van Ecological Quality Objectives van OSPAR (Cook et al. 2014). De indicatoren zijn gepresenteerd in de 'Intermediate Assessment' van OSPAR in 2017 (https://oap.ospar.org/en/osparassessments/intermediate-assessment-2017/). Uitvoering van het meetnet is in handen van Wageningen Marine Research (voorheen IMARES) en Sovon Vogelonderzoek Nederland.

Kennis over de jaarlijkse variatie in broedresultaten is van belang als een early warning systeem om het reproducerend vermogen van de vogelpopulaties in de Waddenzee te volgen, analoog aan het principe van het 'toekomstperspectief' zoals dat in de Vogelrichtlijn wordt verwoord (CBS 2013). Informatie over broedsucces geeft inzicht in de achtergronden voor aantalsveranderingen en een snellere indicatie waar eventueel beleidsmaatregelen zijn te nemen om een (verwachte) negatieve aantalstrend een halt toe te roepen. Negatieve ontwikkelingen bij langlevende soorten (wat de meeste kustbroedvogels zijn) zullen namelijk vaak pas na verloop van tijd tot uiting komen in de aantallen (Van der Jeugd et al. 2014).

De concrete doelstellingen van het meetnet luiden:

- Vaststellen van het reproducerend vermogen van broedvogelpopulaties in de Waddenzee.

- Jaarlijkse monitoring van het broedsucces bij een selectie van soorten in representatieve steekproefgebieden verspreid over de Waddenzee.

Er worden tien soorten broedvogels gevolgd (zie tabel 2.2), ieder representatief geacht voor een bepaalde voedselgroep. Deze selectie is bepaald in trilateraal overleg met TMAP-vertegenwoordigers uit Duitsland en Denemarken.

De resultaten tot nu toe hebben laten zien dat veel broedvogels in de Waddenzee al geruime tijd te kampen hebben met magere broedresultaten (Willems et al. 2005, De Boer et al. 2007, Van Kleunen et al. 2010, Van Kleunen et al. 2012, Koffijberg \& Smit 2013, Koffijberg et al. 2015b, Koffijberg et al. 2016a). Dit geldt niet alleen specifiek voor de Nederlandse Waddenzee, maar ook voor de Duitse en Deense Waddenzee (Thorup \& Koffijberg 2015). Een analyse van alle demografische parameters liet eerder zien dat een laag broedsucces bij de meeste broedvogels een groter probleem is dan veranderingen in jaarlijkse overleving (Van der Jeugd et al. 2014). Bij de laatste trilaterale Ministersconferentie in het Deense Tønder in februari 2014 uitten de ministers uit Nederland, Duitsland en Denemarken in hun Joint Declaration dan ook hun zorgen over de afname van broedvogels in de Waddenzee, veroorzaakt door onder andere de slechte broedresultaten. Dit vormde het vertrekpunt voor een actieplan (Koffijberg et al. 2016b), waarvan een speciale versie in voorbereiding is voor de Nederlandse Waddenzee (opgesteld door Programma Rijke Waddenzee).

\section{Leeswijzer}

Volgend op eerdere rapportages geeft dit rapport een overzicht van de in 2015 en 2016 verzamelde resultaten. Daarnaast worden ontwikkelingen in broedsucces in de periode 2005-2016 gepresenteerd (soms langer, indien gegevens beschikbaar). De opzet van het rapport is basaal van karakter. Belangrijkste doel is het toegankelijk maken van de monitoringgegevens voor verder gebruik. Trends in reproductie zijn tevens per soort online beschikbaar op www.sovon.nl (onder 'Vogelinfo' en 'Landelijk'). Na een korte inleiding over methode en wijze van analyse geven we een algemeen overzicht van de resultaten, gevolgd door een bespreking per soort. In de discussie worden de belangrijkste resultaten samengevat.

\footnotetext{
${ }^{1}$ TMAP: Trilateral Monitoring and Assessment Programme (http://www.waddensea-secretariat.org/monitoring-tmap/about-tmap)
} 


\section{$2 \quad$ Methode en materiaal}

\subsection{Opzet van het Meetnet Reproductie in de Waddenzee}

Het reproductiemeetnet richt zich primair op het verkrijgen van informatie over het aantal vliegvlugge jongen dat per paar wordt geproduceerd (hierna verder broedsucces genoemd, zie Tekstbox 'Definities nestsucces en broedsucces'). Het broedsucces is een belangrijke parameter die ook voor zogenaamde integratieve populatiemonitoring kan worden gebruikt (Reneerkens et al. 2005, Van der Jeugd et al. 2014). Gecombineerd met kennis over overleving (en immigratie/emigratie), afgeleid van in de Waddenzee geringde vogels, biedt het de mogelijkheid populatieveranderingen vanuit demografische gegevens (geboorte en sterfte) te verklaren en te voorspellen (Van der Jeugd et al. 2014, zie ook Schekkerman et al. 2017 voor het Deltagebied).

Het uiteindelijke broedsucces is het resultaat van een optelsom aan factoren die optreden tussen het eerst gelegde ei en het uitvliegen van de jongen. Voorafgaand aan het broeden speelt verder onder andere de conditie van de oudervogels een rol (die kan zijn verlaagd door bijvoorbeeld voedselschaarste voorafgaand aan het broedseizoen, zogenaamde carry-over effecten). Factoren die van belang kunnen zijn tijdens de eifase zijn onder meer predatie of hoge vloeden en tijdens de jongenfase bijvoorbeeld conditie (voedselschaarste) of slecht weer (onderkoeling kuikens). Om te weten te komen in welk stadium van het broedproces de belangrijkste beperkingen liggen, worden daarom naast het uiteindelijke broedsucces ook zoveel mogelijk gegevens verzameld in de nest- en kuikenfase (zie tabel 2.1 voor een overzicht van verzamelde parameters). Inzicht in het slagen of mislukken van legsels (nestsucces) en het uiteindelijke broedsucces biedt aanknopingspunten welke van de factoren in tabel 2.1 van belang zijn. Voor het volgen van nesten wordt aangesloten bij het Meetnet Nestkaarten van Sovon (Van Turnhout 2008). Door de combinatie van het Meetnet Nestkaarten en het Meetnet Reproductie in de Waddenzee kan op efficiënte wijze het broedsucces van kustbroedvogels in de Waddenzee in kaart worden gebracht.

Gegevens zijn ook voor oudere tijdreeksen beschikbaar, zodat de huidige situatie vergeleken kunnen worden met die van voor de introductie van het meetnet. Op deze wijze worden ook ontwikkelingen in de tijd zichtbaar (zie Willems et al. 2005). Welke gegevens in het veld uiteindelijk worden verzameld is afhankelijk van de soort. Voor in kolonies broedende soorten (meeuwen en sterns) kan het gehele broedproces met de juiste technieken goed worden gevolgd. Bij meer verspreid of verborgen broedende soorten (bijv. Eider) wordt het volgen in de eifase lastiger, mede ook vanuit oogpunt van verstoring. Kluten daarentegen gaan na het uitkomen van de eieren met hun jongen weg uit de buurt van het nest, en zijn juist in de kuikenfase moeilijker te volgen. De gebruikte werkwijze in het veld moet dus worden afgestemd op het gedrag van de tien meetsoorten (zie verder paragraaf 2.3).

Definities nestsucces en broedsucces

Dit rapport gaat over het broedsucces van kustbroedvogels in de Waddenzee. De term broedsucces heeft hier exclusief betrekking op het uiteindelijk aantal vliegvlugge jongen per paar (in de gemeten steekproef, of in het hele telgebied, indien in het hele telgebied broedsucces werd gemeten). Het succesvol uitkomen van legsels, elders ook broedsucces genoemd, wordt in dit rapport consequent als nestsucces gedefinieerd. Dit nestsucces wordt weergegeven op de klassieke manier (percentage uitgekomen nesten) of als nestsucces $\mathrm{H}$ met behulp van de Mayfield methode, al naar gelang de beschikbaarheid van de gegegevens. Deze berekening gaat uit van de dagelijkse overlevingskansen van legsels, in combinatie van met de ligduur van een legsel (Beintema 1992). Mayfield-getallen worden alleen opgenomen voor soorten waarvan nesten goed werden gevolgd. Voor het overige wordt vooral het klassieke nestsucces gebruikt, dat als handicap heeft dat het het succes van nesten overschat (Beintema 1992). Alleen in geval van nesten die intensief worden gevolgd, is het klassieke nestsucces vergelijkbaar met nestsucces zoals die uit Mayfield-berekeningen komt. 


\subsection{Stratificatie en steekproefgrootte}

De in tabel 2.1 genoemde factoren kunnen binnen de Waddenzee sterk variëren. Zo is bijvoorbeeld het risico van predatie langs de vastelandskust doorgaans groter dan op de eilanden, waar veel landpredatoren (Vos, marterachtigen) ontbreken. Ook is de voedselsituatie niet in de hele Waddenzee gelijk, bijvoorbeeld als gevolg van verschillen tussen de westelijke en de oostelijke Waddenzee in de beschikbaarheid van mosselbanken. Voor een representatief overzicht is het dus van belang om gegevens uit verschillende delen van de Waddenzee te verzamelen. Om een goede spreiding in habitats en ligging van locaties te verkrijgen, wordt er in het reproductiemeetnet naar gestreefd om voldoende stratificatie van meetpunten te hebben over gebieden en habitats. Om te komen tot een 'gemiddeld broedsucces' voor de hele Waddenzee wordt een weging toegepast naar de grootte van de onderzochte broedpopulaties (zie verder paragraaf 2.5).

Tabel 2.1. Overzicht van verzamelde parameters in het Meetnet Reproductie in de Waddenzee, onderscheiden naar eifase en kuikenfase. Tevens zijn de belangrijkste factoren genoemd die de uitkomst van deze parameters kunnen beïnvloeden en/of welke indicatorwaarde de resultaten hebben. Het overzicht geeft een algemeen beeld en kan in detail afwijken, afhankelijk van de soort. [Parameters recorded for monitoring breeding success of coastal breeding birds in the Dutch Wadden Sea, including their indicator value].

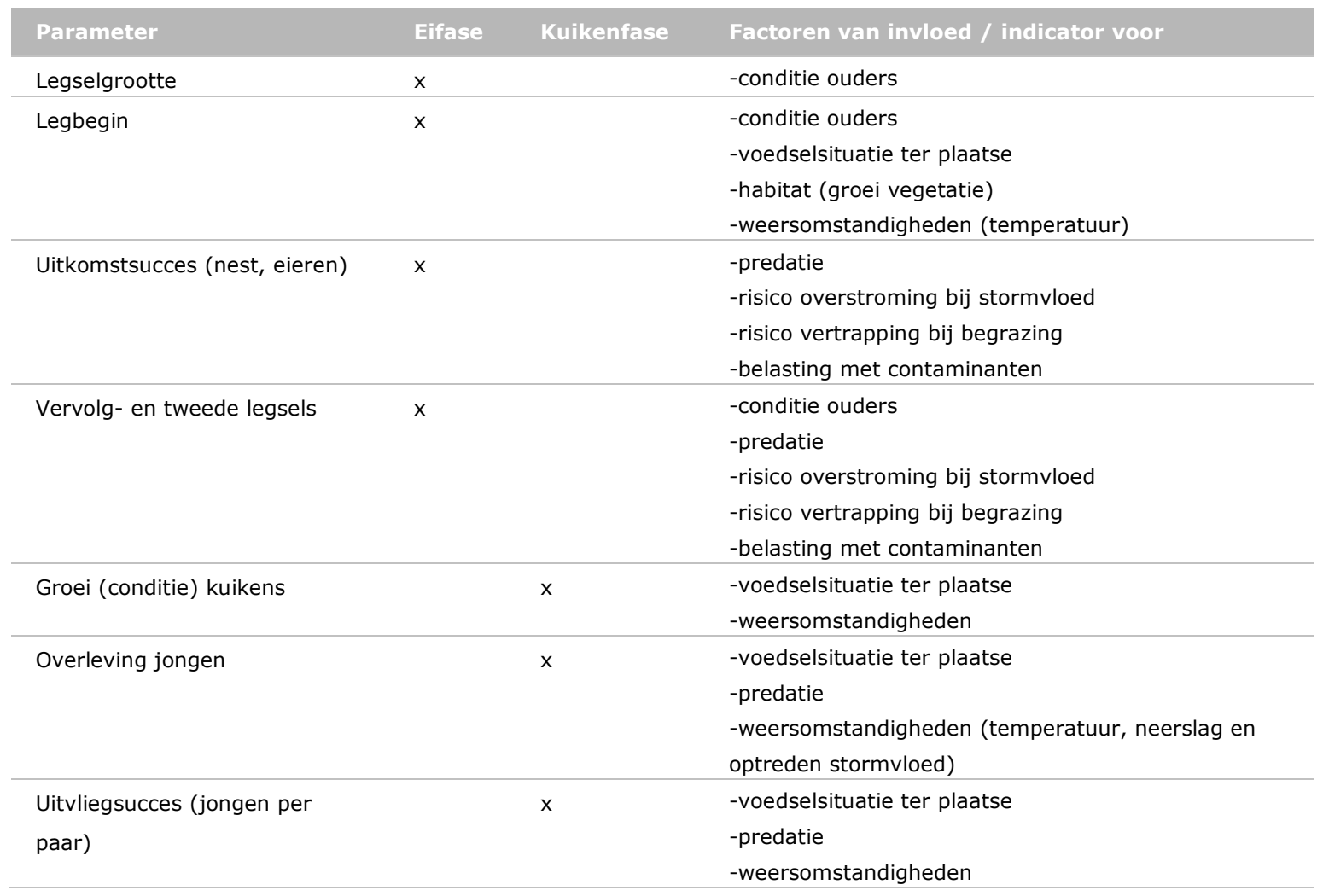

\subsection{Uitvoering veldwerk in 2015-2016}

De coördinatie en de uitvoering van het veldwerk voor het reproductiemeetnet wordt uitgevoerd door Sovon Vogelonderzoek Nederland (grootste deel Waddengebied) en Wageningen Marine Research (intensieve populatiestudie Scholekster Texel). Om het veldwerk aan te sturen, is geput uit de poule aan vrijwilligers, vogelwachters en andere medewerkers van terreinbeheerders, aangevuld met professionele inzet van veldmedewerkers van Sovon. Door de jaren heen gaat het om een betrekkelijk kleine groep deelnemers. In een aantal gevallen zijn gegevens afgeleid van speciale projecten, zoals de monitoring van sterns in de Eemshaven vanwege overlast bij daar gevestigde bedrijven. Voor gegevens van Lepelaar wordt samengewerkt met de Werkgroep Lepelaar. Op Texel (Kelderhuispolder) voert Kees Camphuysen (NIOZ) intensief onderzoek uit aan Kleine Mantelmeeuw en Zilvermeeuw. De vogelwachters van Griend en Rottumerplaat meten voor verschillende soorten broedsucces (Lutterop \& Kasemir 2016, 2017). Alle veldmedewerkers, voor zover aangestuurd door Sovon, zijn voorzien van een speciale instructie, afgeleid van de Engelstalige trilaterale handleiding voor het monitoren van broedsucces (Koffijberg et al. 2011). 
De uitvoering van het veldwerk verschilde per soort. Oosterhuis et al. (2004) en Koffijberg et al. (2011) geven een overzicht van de gangbare methodieken per soort en beschrijven de methodes in detail. Tabel 2.2 geeft op hoofdlijnen inzicht hoe de gegevens per soort werden verzameld. Richtlijnen voor het uitvoeren van nestonderzoek staan ook per soort online op www.sovon.nl ('Vogelinfo').

Tabel 2.2. Overzicht van de in deze studie gehanteerde methodes per soort (voor details zie Oosterhuis et al. 2004, en Koffijberg et al. 2011). [Overview of methods used during fieldwork in the monitoring scheme of breeding success of coastal breeding birds in the Dutch Wadden Sea.]

\begin{tabular}{|c|c|}
\hline Soort & Werkwijze \\
\hline Lepelaar & Telling grote jongen in kolonie \\
\hline Eider & Telling grote jongen rond 1 juli; volgen beperkt aantal nesten op Vlieland \\
\hline Scholekster & Volgen nesten en telling (bijna) vliegvlugge jongen op locaties met bekend aantal broedparen \\
\hline Kluut & Volgen nesten en telling (bijna) vliegvlugge jongen op locaties met bekend aantal broedparen \\
\hline Kokmeeuw & $\begin{array}{l}\text { Volgen nesten en schatten jongenproductie afzonderlijke kolonie, waar nodig door gebruik te maken } \\
\text { van enclosure }\end{array}$ \\
\hline $\begin{array}{l}\text { Kleine } \\
\text { Mantelmeeuw }\end{array}$ & $\begin{array}{l}\text { Volgen nesten en schatten jongenproductie afzonderlijke kolonie, waar nodig door gebruik te maken } \\
\text { van enclosure }\end{array}$ \\
\hline Zilvermeeuw & $\begin{array}{l}\text { Volgen nesten en schatten jongenproductie afzonderlijke kolonie, waar nodig door gebruik te maken } \\
\text { van enclosure }\end{array}$ \\
\hline Grote Stern & $\begin{array}{l}\text { Volgen nesten en schatten jongenproductie afzonderlijke kolonie, waar nodig door gebruik te maken } \\
\text { van enclosure }\end{array}$ \\
\hline Visdief & $\begin{array}{l}\text { Volgen nesten en schatten jongenproductie afzonderlijke kolonie, waar nodig door gebruik te maken } \\
\text { van enclosure }\end{array}$ \\
\hline Noordse Stern & $\begin{array}{l}\text { Volgen nesten en schatten jongenproductie afzonderlijke kolonie, bij voorkeur door gebruik te maken } \\
\text { van enclosure }\end{array}$ \\
\hline
\end{tabular}

In het broedseizoen van 2015 werden in totaal voor 65 soort/gebiedscombinaties-gegevens verzameld (tabel 2.3, figuur 2.1). Scholekster, Kokmeeuw en Visdief werden het meest intensief en het meest verspreid over de Waddenzee onderzocht. In 2016 bedroeg het aantal meetlocaties eveneens 65 . Scholekster en Visdief waren het best vertegenwoordigd. In de meeste gevallen worden voor specifieke soorten jaarlijks dezelfde locaties gevolgd. In 2016 werd extra aandacht besteed aan de binnendijkse broedplaatsen aan de Waddenkust op Texel. Terschelling en de Friese Waddenkust zijn slecht vertegenwoordigd in het meetnet, ondanks gerichte pogingen om hier via de terreinbeheerder of vrijwilligers broedsucces-gegevens te verzamelen

Tabel 2.3. Overzicht van het in 2015 en 2016 verzamelde materiaal van reproductiegegevens voor alle bestudeerde soorten. Weergegeven is het aantal gebieden/kolonies waar gegevens werden verzameld. Overview of data collection in 2015-2016. [For each site-species combination the number of sample sites is given.]

\begin{tabular}{|c|c|c|c|c|c|c|c|c|c|c|}
\hline Gebied 2015 & $\begin{array}{l}\frac{1}{10} \\
\frac{10}{10} \\
\frac{0}{10}\end{array}$ & $\frac{1}{\frac{1}{0}}$ & 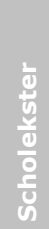 & $\frac{\underline{z}}{\frac{3}{3}}$ & है & $\frac{\bar{y}}{\frac{10}{2}}$ & 产 & $\begin{array}{l}\frac{5}{2} \\
\frac{9}{8} \\
\frac{8}{6} \\
\frac{3}{8} \\
\frac{5}{6}\end{array}$ & $\begin{array}{l}\frac{1}{10} \\
\frac{0}{5} \\
\frac{0}{3}\end{array}$ & 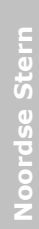 \\
\hline Ameland & 1 & 1 & 1 & & 1 & & & 1 & 1 & 1 \\
\hline Balgzand/Wieringen & & & 1 & & & & & & & \\
\hline Griend & 1 & & & & 1 & & & 1 & 1 & 1 \\
\hline Eems/Dollard & & & 1 & 1 & 3 & & & & 2 & 3 \\
\hline Noordkust Groningen & & & 1 & 2 & 1 & & & & 1 & 1 \\
\hline Rottumerplaat & & 1 & & & & 1 & 1 & & & \\
\hline Schiermonnikoog & 1 & 1 & 3 & & 1 & 1 & 1 & & 1 & \\
\hline Terschelling & & 1 & & & 1 & & & & & 1 \\
\hline Texel & & 1 & 2 & 2 & 2 & 2 & 2 & 1 & 2 & \\
\hline Vlieland & & 2 & & 1 & & 1 & 1 & & 1 & 1 \\
\hline
\end{tabular}




\section{Vervolg tabel 2.3}

\begin{tabular}{|c|c|c|c|c|c|c|c|c|c|c|}
\hline Gebied 2016 & $\frac{\frac{1}{d 0}}{\frac{10}{d 0}}$ & $\frac{\text { 훙 }}{\frac{1}{0}}$ & $\begin{array}{l}\frac{1}{d} \\
\frac{y}{y} \\
\frac{0}{0} \\
\frac{\partial}{0} \\
\text { un }\end{array}$ & 芦 & 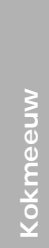 & $\frac{\bar{d}}{\frac{1}{2}}$ & $\frac{3}{3}$ & 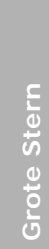 & $\begin{array}{l}\text { 둥 } \\
\frac{1}{5} \\
\frac{1}{5}\end{array}$ & 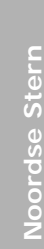 \\
\hline Ameland & 1 & & 1 & & 1 & & & 1 & & \\
\hline Balgzand/Wieringen & & & 1 & & & & & & & \\
\hline Griend & 1 & 1 & 1 & & 1 & & & 1 & 1 & 1 \\
\hline Eems/Dollard & & & 1 & & 3 & & & & 3 & 3 \\
\hline Noordkust Groningen & & & 2 & 2 & 1 & & & & 1 & 1 \\
\hline Rottumerplaat & 1 & & & & 1 & 1 & 1 & & & \\
\hline Schiermonnikoog & 1 & & 2 & & & 1 & 1 & & & \\
\hline Texel & & 1 & 4 & 6 & 2 & 1 & 1 & 2 & 2 & 1 \\
\hline Vlieland & & 2 & & 1 & & 1 & 1 & & 1 & 1 \\
\hline
\end{tabular}
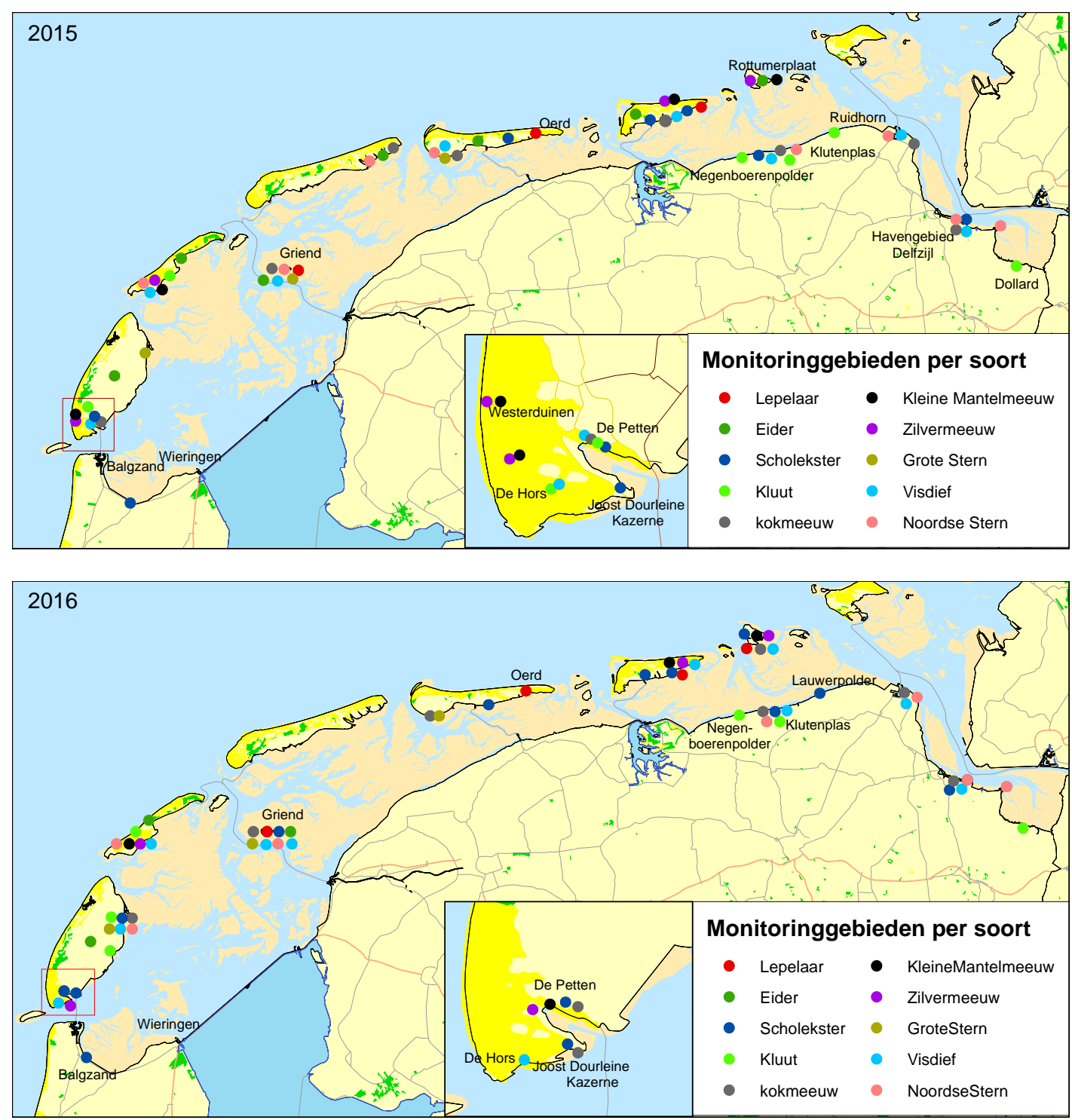

Figuur 2.1. Overzicht van het in 2015 en 2016 verzamelde materiaal van reproductiegegevens voor alle meetnet-soorten. Weergegeven is op welke locaties voor welke soorten gegevens werden verzameld. [Overview of data collection in 2015-2016 (combinations of species x site, multiple samples at one site only presented once)]. 


\subsection{Verwerking van gegevens}

Gegevens over de lotgevallen van nesten werden verwerkt via het Meetnet Nestkaarten van Sovon/ CBS. Dit project is onderdeel van het Netwerk Ecologische Monitoring (NEM) en heeft onder andere tot doel verschuivingen in het begin van de eileg te volgen, als graadmeter voor klimaatveranderingen (zie Van Turnhout 2008). Invoer van de veldgegevens gebeurt met de speciale software 'Nestkaart' (zie bijlage 4 in Willems et al. 2005), en verloopt geheel digitaal. De ingevoerde gegevens zijn vervolgens gekoppeld aan de database van het Meetnet Reproductie. Deze database is online toegankelijk voor de waarnemers. In deze database is informatie over de locatie, soort, (globale) lotgevallen van legsels, lotgevallen van kuikens, het aantal uitgevlogen jongen per paar en eventuele aanvullende opmerkingen opgeslagen. Voor de analyse worden beide databases uitgelezen en gecontroleerd op onwaarschijnlijkheden en dubbele records. Uit de definitieve output werden de tabellen voor deze rapportage gegenereerd. In geval van twijfel over de kwaliteit van de gegevens, of in geval van sommige hele kleine steekproeven, werden de gegevens niet meegenomen in de verdere analyses zoals beschreven in paragraaf 2.5 .

\section{$2.5 \quad$ Analyses}

Uit de verzamelde gegevens zijn primair twee belangrijke parameters geanalyseerd, te weten het nestsucces (uitkomstsucces) en het broedsucces (het aantal vliegvlugge jongen per broedpaar). Het nestsucces wordt in dit rapport zoveel mogelijk gebaseerd op analyses met de Mayfield-methode (Beintema 1992); alleen bij kleine steekproeven wordt teruggegrepen op het klassieke nestsucces, ofwel de verhouding succesvolle/niet-succesvolle nesten. De laatste leidt in de meeste situaties (tenzij er vrijwel dagelijks een controle plaatsvindt) tot een overschatting van het broedsucces (Beintema 1992). Mayfield gaat uit van een dagelijkse overlevingskans $p$ : de kans dat een nest dat vandaag wordt gevonden er ook morgen nog ligt. Door deze kansen te bepalen over de hele eifase ('ligduur') wordt het uitkomstsucces $H$ berekend (zie Willems et al. 2005 voor verdere details).

Het uiteindelijke aantal vliegvlugge jongen per paar is berekend door het aantal (bijna) vliegvlugge jongen te delen door het vastgestelde aantal broedparen, hetzij in de steekproef waar broedsucces is gemonitord, hetzij in het hele telgebied, of in de hele kolonie. Bij Eidereend wordt het aantal jongen zelfs bepaald voor een heel eiland. Dit gebeurt via soort-specifieke methodes (zie eerder). Voor Eider en Kluut worden voor dat doel speciale jongentellingen georganiseerd, voor de in kolonies broedende meeuwen en sterns wordt dit deels door middel van enclosures, en deels door middel van vangstterugvangst methodieken bepaald (zie Koffijberg et al. 2011 voor details). Voor Scholekster is in een klein aantal telgebieden voor de reguliere broedvogelinventarisaties begin juli een jongentelling uitgevoerd. In sommige gevallen was alleen een schatting mogelijk van het aantal uitgevlogen jongen.

Voor de analyse van trends in broedsucces in 2005-2016 is dezelfde werkwijze gevolgd als bij de rapportage over 2013. Om tot een 'gemiddeld' broedsucces voor de gehele Waddenzee te komen, is een speciaal regressiemodel opgesteld, dat rekening houdt met de grootte van de bemonsterde populatie, de kwaliteit van de verzamelde gegevens (nauwkeurige meting of schatting) en het feit dat niet overal elk jaar op dezelfde locatie gegevens worden verzameld (Van der Jeugd et al. 2014). De kwaliteit van de meetmethode en de koloniegrootte zijn gecombineerd in één weegfactor als: kwaliteitsscore $x$ aantal broedparen in kolonie/gebied. De kwaliteitsscore $(0,5,1$ of 2$)$ reflecteert hierbij de nauwkeurigheid van de schatting, terwijl de koloniegrootte ruwweg weerspiegelt van welk aandeel van de Waddenpopulatie de gemeten waarde het broedsucces representeert. Omdat bij de meeste soorten de variatie in aantal paren per locatie (koloniegrootte) veel groter is dan een factor 4 (de spreiding van de kwaliteitsscores) weegt de koloniegrootte zwaarder dan de kwaliteitsscore.

Een intensief onderzochte kolonie van 100 paren krijgt dan bijvoorbeeld gewicht $2 \times 100=200$, een minder nauwkeurig gemeten kolonie van 500 paren $1 \times 500=500$. Uit de gewogen gegevens is vervolgens een trend berekend met behulp van Poissonregressie. Dit is een Gegeneraliseerd Lineair Model (GLM) met logaritmische linkfunctie en semi-Poisson verdeelde variantie met een uit de data geschatte dispersiefactor. Dit model reflecteert dat het broedsucces niet kleiner kan zijn dan 0 en is minder gevoelig voor hoge uitschieters en aggregatie in de gegevens dan een lineair model. Naast een 
(op de logaritmische schaal) lineair effect van jaar is in het model ook de factor gebied opgenomen. Zo wordt de langjarige trend geschat met correctie voor systematische verschillen in broedsucces tussen gebieden, en weergegeven als het (gewogen) gemiddelde over deze gebieden. In de grafieken worden de gewogen jaargemiddelden weergegeven als stippen en de trend als een lijn (gestippeld indien niet significant), met het bijbehorende $95 \%$ betrouwbaarheidsinterval. Voor enkele soorten zijn voor twee tijdsperiodes trends berekend (lange termijn en periode van 2005-2016). De classificatie van de trend volgt de systematiek zoals Sovon/CBS die hanteren voor de aantalsveranderingen bij het Meetnet Broedvogels en Meetnet Watervogels (bijv. Boele et al. 2016). 


\section{Weersomstandigheden in voorjaar 2015 en 2016}

Onderstaand overzicht is gebaseerd op weersgegevens van het KNMI, toegankelijk via www.knmi.nl, aangevuld met ervaringen van veldwerk in de Waddenzee in het broedseizoen van 2015 en 2016.

\subsection{Weersomstandigheden en waterstanden in 2015}

Het broedseizoen van 2015 volgde op een vrij zachte winter, met in De Bilt een gemiddelde temperatuur die ruim boven het normale winter-gemiddelde lag. Februari had de laagste temperaturen van de winter, maar het voorjaar nam in maart een aanloop naar een duidelijk warmer weertype (vooral in Noord-Nederland). De storm aan het eind van deze maand (29 en 31 maart) had gezien het vroege tijdstip nauwelijks invloed op kustbroedvogels. In april domineerden hogedrukgebieden boven de Britse Eilanden het weerbeeld. Dit leidde tot een droog maar uitgesproken koel weertype. Wind van zee bepaalde het beeld, met vooral in de Waddenzee lage temperaturen (figuur 3.1). In het binnenland kwam op 17 van de 30 dagen nog vorst aan de grond voor.

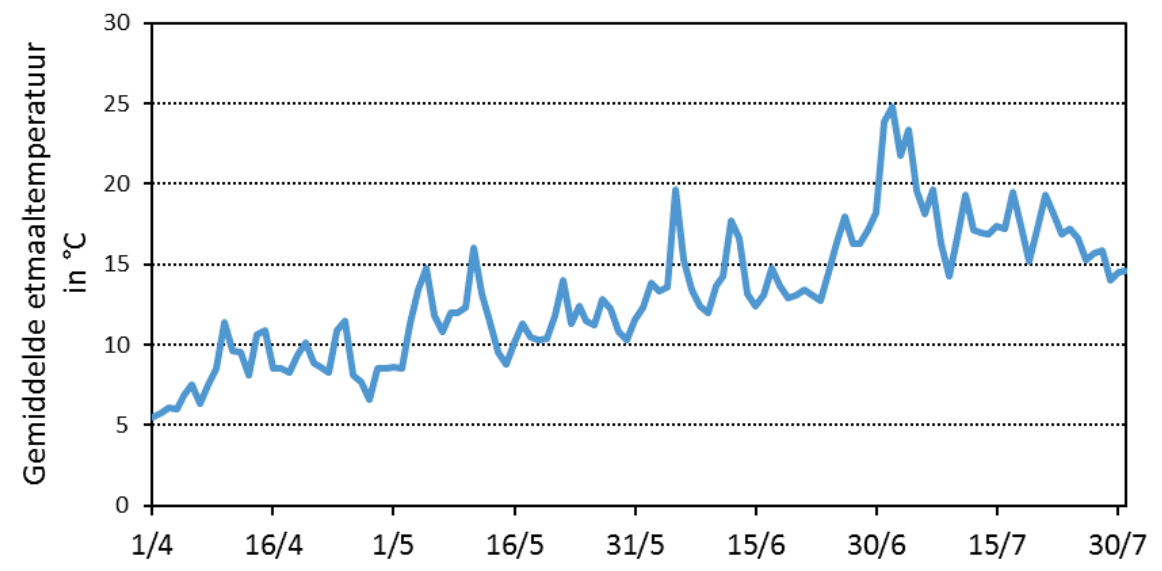

Figuur 3.1. Gemiddelde temperatuur in graden Celsius gemeten in Lauwersoog in de periode 1 april - 31 juli 2015. Bron: KNMI. [Average temperature during the fieldwork season in 2015 for Lauwersoog].

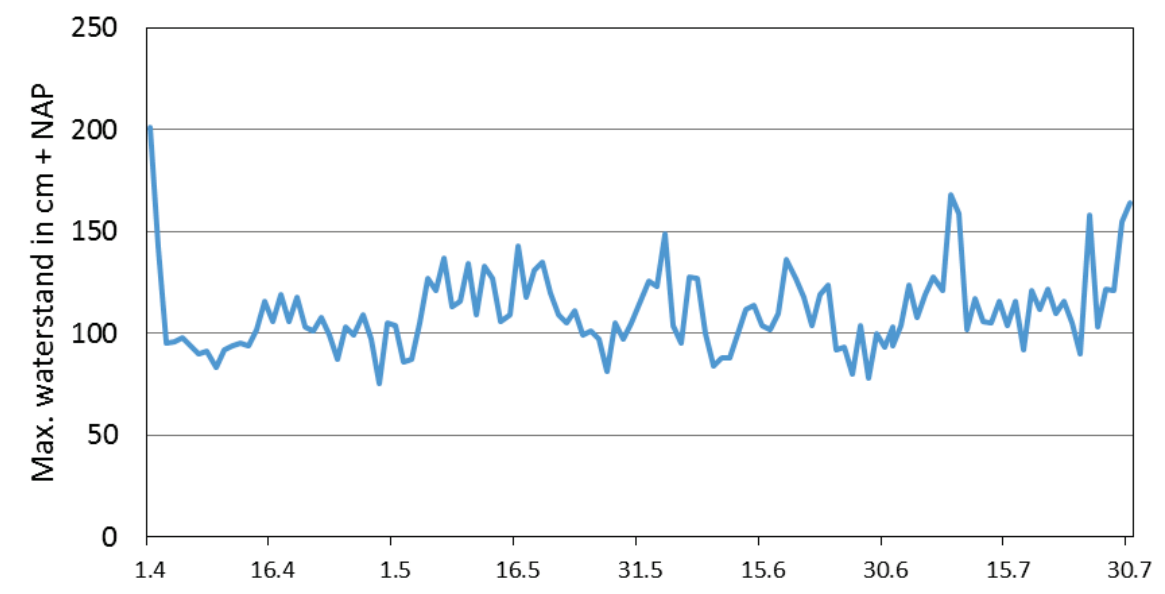

Figuur 3.2. Maximale waterstanden $(\mathrm{cm}+\mathrm{NAP})$ per etmaal gemeten in Lauwersoog in de periode 1 april 31 juli 2015, ter indicatie van frequentie van extreem hoog water. Bron: Rijkswaterstaat (http://live.waterbase.nl/waterbase_wns.cfm?taal=nl). [High tide water levels at Lauwersoog, as a proxy for extreme high tides in spring 2015]. 
Dit weerbeeld heerste ook in mei en juni. Mei was zelfs landelijk aan de koude kant. Harde wind zorgde plaatselijk in de Waddenzee voor zandstormen. Door de aanlandige wind kwam het eveneens meerdere keren tot kleinere stormvloeden. De stormvloed op 2 en 3 juni had de meeste gevolgen voor broedvogels, met o.a. water op lage delen van de kwelders. De gevolgen waren echter niet voor alle soorten even slecht omdat de stormvloed vooral lokaal van aard was. Kleinere stormvloeden waren er op 18-19 mei en 8-9 juli (figuur 3.2). Op 8 juli stond de kwelder van de Groninger Noordkust grotendeels onder water. Op dat moment waren alle jonge Kluten groot en (bijna) vliegvlug. Het effect van de overstroming op jongen van andere soorten is onbekend.

\subsection{Weersomstandigheden en waterstanden in 2016}

De winter van 2015/16 was de op één na zachtste sinds de start van de weermetingen in 1706 . In de eerste drie maanden van het voorjaar (maart-mei) waren de temperaturen overeenkomstig het langjarig gemiddelde, en lagen hoger dan in het voorjaar van 2015. Vooral maart en de tweede helft van april waren aan de koele kant (in april zelfs plaatselijk nog sneeuw in het noorden van het land). Eind mei waren er enkele dagen met zware (onweers)buien. Juni was warmer dan normaal. Zowel qua temperatuur, als het optreden van harde aanlandige wind (en stormvloeden) was het voorjaar van 2016 voor broedvogels gunstiger dan het voorjaar van 2015. Grootschalige stormvloeden kwamen niet voor.

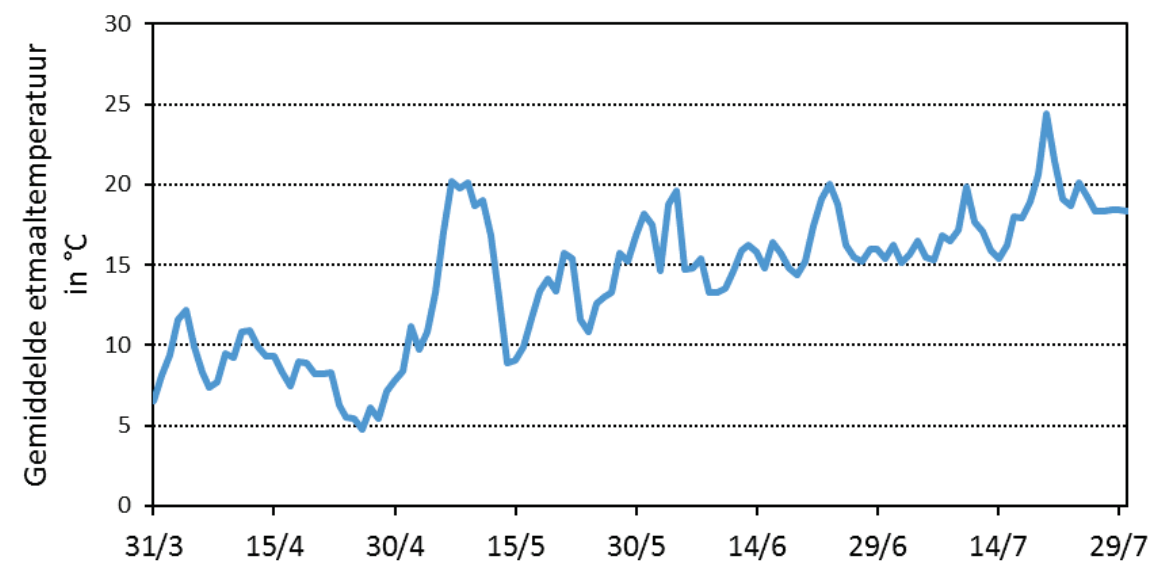

Figuur 3.3. Gemiddelde temperatuur in graden Celsius gemeten in Lauwersoog in de periode 1 april - 31 juli 2016. Bron: KNMI. [Average temperature during the fieldwork season in 2016 for Lauwersoog].

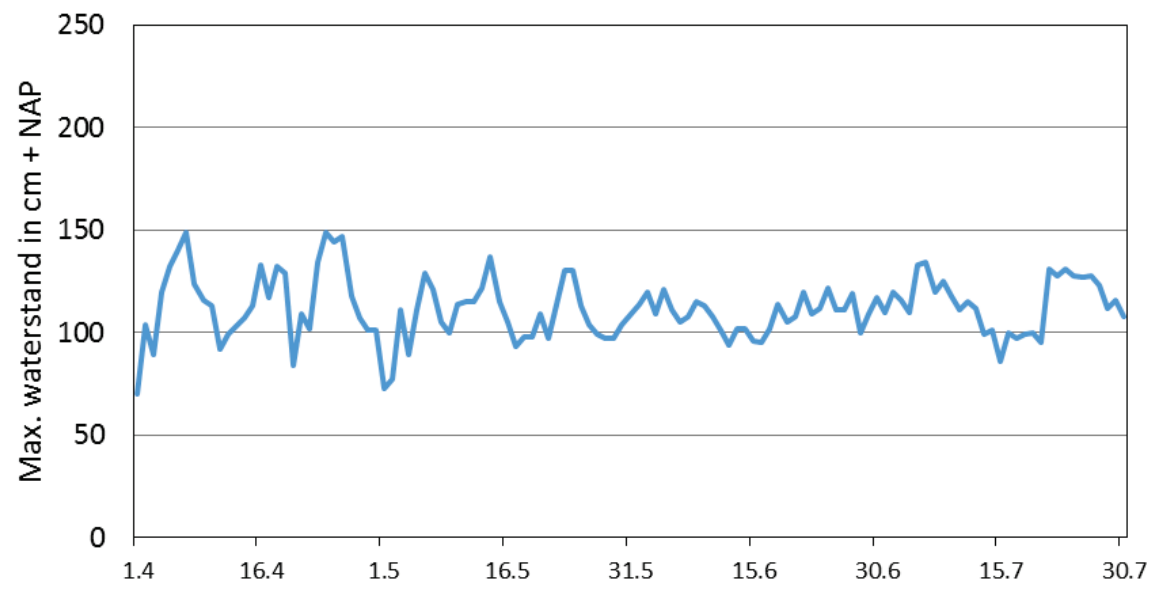

Figuur 3.4. Maximale waterstanden ( $\mathrm{cm}+N A P)$ per etmaal gemeten in Lauwersoog in de periode 1 april 31 juli 2016, ter indicatie van frequentie van extreem hoog water. Bron: Rijkswaterstaat (http://live.waterbase.nl/waterbase_wns.cfm?taal=nl). [High tide water levels at Lauwersoog, as a proxy for extreme high tides in spring 2016.] 


\section{$4 \quad$ Resultaten}

\subsection{Algemeen}

In dit hoofdstuk worden de resultaten van de tien meetnetsoorten afzonderlijk besproken. Per soort wordt een beknopte beschrijving gegeven van het voorkomen en de trends in de Waddenzee tot en met 2015-2016, afgeleid van de broedvogeltellingen die in het kader van het Netwerk Ecologische Monitoring (Meetnet Broedvogels van Sovon/CBS) worden uitgevoerd (zie ook Boele et al. 2016). Waar mogelijk wordt de situatie in de context van de hele internationale Waddenzee geplaatst (Koffijberg et al. 2015a). Deze bronnen worden in de tekst niet steeds afzonderlijk genoemd. Voor de relevante soorten wordt de huidige broedpopulatie afgezet tegen de instandhoudingsdoelstellingen zoals die in het Natura 2000-beheerplan voor de Waddenzee worden genoemd (zie ook www.sovon.nl onder vogelinfo en gebieden).

Vervolgens presenteren we informatie over het broedsucces in 2015 en 2016. De presentatie is basaal van aard en geeft een algemene beschrijving van het broedsucces in beide jaren. Eventueel worden beperkingen van de gegevens aangegeven (kleine steekproef). Tot slot wordt een analyse van ontwikkelingen in broedsucces sinds de start van het meetnet in 2005 gepresenteerd. Voor enkele soorten, waarvan een langere reeks beschikbaar was in de database, is ook een analyse voor een langere reeks gemaakt (Lepelaar, Scholekster, Kokmeeuw, Grote Stern, Visdief) en worden twee afzonderlijke figuren gepresenteerd. Hiervoor werd gebruik gemaakt van de gegevens die zijn verzameld door Van der Jeugd et al. (2014) bij hun review van demografische parameters van vogels in de Waddenzee.

Voor het opstellen van de soortteksten is veel informatie ontleend aan eerder verschenen rapportages over het reproductiemeetnet Waddenzee (Willems et al. 2005, de Boer et al. 2007, van Kleunen et al. 2010, 2012, Koffijberg et al. 2015b, Koffijberg et al. 2016a). Tevens is gebruik gemaakt van het internationale overzicht dat in het kader van TMAP werd gemaakt door Thorup \& Koffijberg (2015). Het aantal jongen dat nodig is om de populatie op z'n minst stabiel te houden is ontleend aan Koffijberg \& Smit (2013), zie ook Thorup \& Koffijberg (2015) voor aanvullingen. Specifieke bronnen in de tekst worden alleen genoemd als het niet om één van de bovenstaande publicaties gaat.

\subsection{Lepelaar Platalea leucorodia - Eurasian Spoonbill}

\section{Populatie en trend}

De Waddenzee is de belangrijkste regio voor broedende Lepelaars in Nederland. Vrijwel alle grote kolonies liggen op de eilanden en ruim de helft van het landelijke aantal broedparen huist in de Waddenzee. In tegenstelling tot de landelijke trend begint het aantalsverloop in de Waddenzee tekenen van stabilisatie te vertonen (en dan vooral de oostelijke Waddenzee). De populatie is evenwel groter dan het eerder door Lok et al. (2009) veronderstelde evenwicht. De afvlakking is gevolg van dichtheids-afhankelijke effecten op broedsucces en overleving (Lok et al. 2009, Lok et al. 2013).

Nieuwe analyses veronderstellen een lokaal effect, veroorzaakt door de hoeveelheid voedsel in de omgeving van de kolonie (Oudman et al. 2017). In de Duitse Waddenzee is nog sprake van een duidelijke groei van het aantal broedende Lepelaars, al worden lokaal problemen gemeld met predatie (bijv. Hallig Oland in Sleeswijk-Holstein, B. Hälterlein). Ondanks de stabilisatie van de aantallen ligt het aantal broedvogels in de Waddenzee duidelijk boven de instandhoudingsdoelstellingen die voor Natura 2000 in de Waddenzee gelden (figuur 4.1).

Reproductiegegevens van Lepelaars in de Waddenzee worden verzameld door de Werkgroep Lepelaar, in het kader van het Metawad project. Er worden alleen gegevens omtrent het broedsucces verzameld. Nestcontroles worden uit oogpunt van verstoring vermeden 


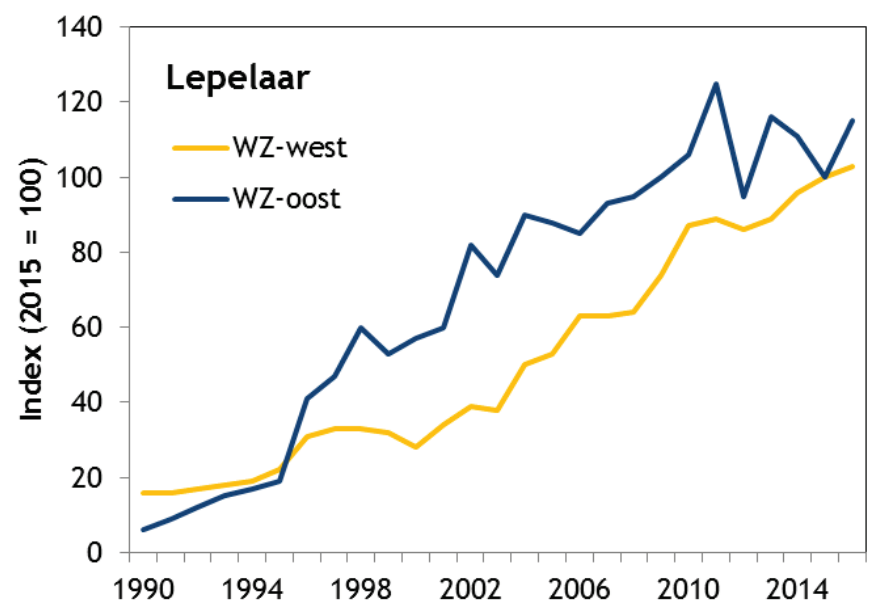

Figuur 4.1. Trends in aantallen broedparen Lepelaars in de Waddenzee (index), gesplitst naar Westelijke Waddenzee (west van wantij Terschelling) en oostelijke Waddenzee (tot Eemshaven). Gegevens broedvogelmeetnet Sovon/CBS. [Trends in numbers of breeding pairs (expressed as index) for Eurasian Spoonbill in the western and eastern Wadden Sea].

\section{Reproductie 2015}

Gegevens waren beschikbaar van drie kolonies, van in totaal 372 paar. Het broedsucces varieerde van 0,5 jong per paar op Griend tot 1,56 jong per paar op Oerd/Hon/Ameland.

\section{Reproductie 2016}

Voor 2016 zijn de gegevens nog niet volledig beschikbaar. Op Rottumerplaat (69 paren) werden 1,3 jongen per paar vliegvlug, op Griend (46 paar) 1,0 jong/paar.

\section{Ontwikkelingen sinds 2005 en discussie}

Zowel op de lange termijn (vanaf 1992) als sinds de start van het meetnet reproductie (2005) produceerden Lepelaars significant minder jongen, zoals ook reeds door Lok et al. $(2009,2013)$ en Van der Jeugd et al. (2014) beschreven (figuur 4.2). De Lepelaar is een voorbeeld van een soort die een succes-volle kolonisatie van de (Nederlandse) Waddenzee achter de rug heeft, en nu (plaatselijk) kennelijk tegen de grenzen van het leefgebied aan loopt. De hoeveelheid voedsel in de omgeving van de kolonie speelt hierbij een belangrijke rol (Oudman et al. 2017). Metingen aan kuikens in zes verschillende kolonies tussen 2011-2015 lieten ook zien dat de conditie van het eerste cohort kuikens in stabiele kolonies slechter was dan die in groeiende kolonies (Oudman et al. 2017).
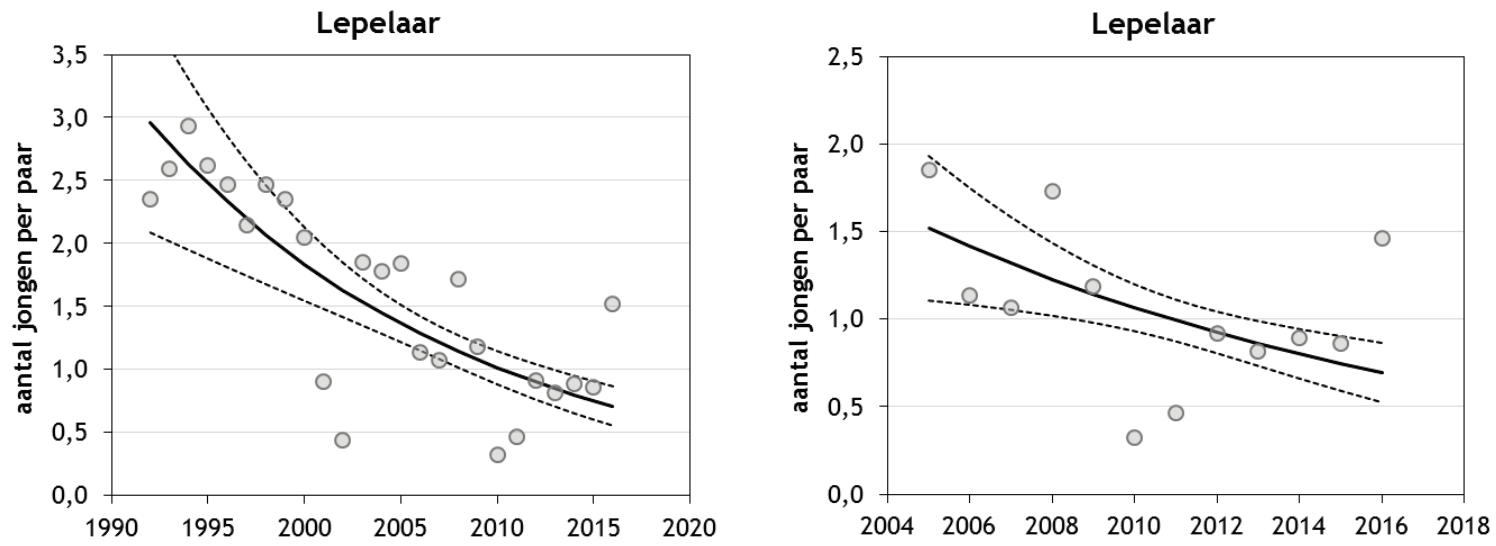

Figuur 4.2. Trend in broedsucces voor Lepelaar, voor de periode 1992-2016 (links) en de periode 20052016 (rechts). Voor beide periode is er een matige afname (resp. $p<0,001$ en $p=0,002$ ). Gegevens Werkgroep Lepelaar. [Trend in breeding success (fledged young per pair) in Eurasian Spoonbill in the Dutch Wadden Sea in 1992-2016 (left panel) and 2005-2016 (right panel). For both periods a significant decrease in reproductive output was recorded.] 
Inzicht in de kolonie-specifieke foerageergebieden van de verschillende Lepelaars gecombineerd met metingen aan het voedselaanbod zou meer licht kunnen werpen hoe het mechanisme van de voedselbeperking precies in z'n werk gaat. Of, en wanneer Lepelaars ook in de Duitse en Deense Waddenzee dergelijke beperkingen tegenkomen zullen toekomstige inventarisaties moeten uitwijzen. Tot nu toe zet de toename van Lepelaars in de Duitse Waddenzee onverminderd door: in 2017 werd in Sleeswijk-Holstein een groei van 25\% ten opzichte van 2016 opgetekend (K. Günther/Schutzstation Wattenmeer).

\subsection{Eider Somateria mollissima - Common Eider}

\section{Populatie en trend}

Vrijwel alle Nederlandse Eiders broeden in de Waddenzee. Broedpopulaties in de Duitse en Deense Waddenzee zijn erg klein in vergelijking met die in Nederland. Gegevens van de nieuwe vogelatlas van 2013-2015 wijzen op een (landelijke) populatie van 5500-6700 paren, die voor meer dan 95\% in de Waddenzee voorkomt. De ruime marge wordt deels veroorzaakt door de moeilijke telbaarheid van de soort, omdat de huidige telmethode gebruik maakt van de verhouding man : vrouw, en er aanwijzingen zijn dat die is veranderd. Daarnaast zijn in de afgelopen jaren enkele gaten in de telreeksen gevallen (o.a. Boschplaat, Terschelling). Het verloop van het aantal broedparen in de Waddenzee kende in de afgelopen dertig jaar verder sterke schommelingen en periodiek massale sterfte, veroorzaakt door voedselschaarste (o.a. Camphuysen et al. 2002, Kats 2007). Na een dieptepunt rond 2010 lijkt het aantal in de oostelijke Waddenzee momenteel uit een dal te kruipen, maar de trend wordt door sterke fluctuaties gekenmerkt (mogelijk mede veroorzaakt door telproblemen). Nog steeds zit het aantal broedvogels in de hele Waddenzee onder de geformuleerde instandhoudingsdoelstelling in het Natura 2000-beheerplan. Vanaf 1990 gerekend is de trend significant negatief, over de laatste tien jaar onzeker (hele Waddenzee stabiel), zie figuur 4.3.

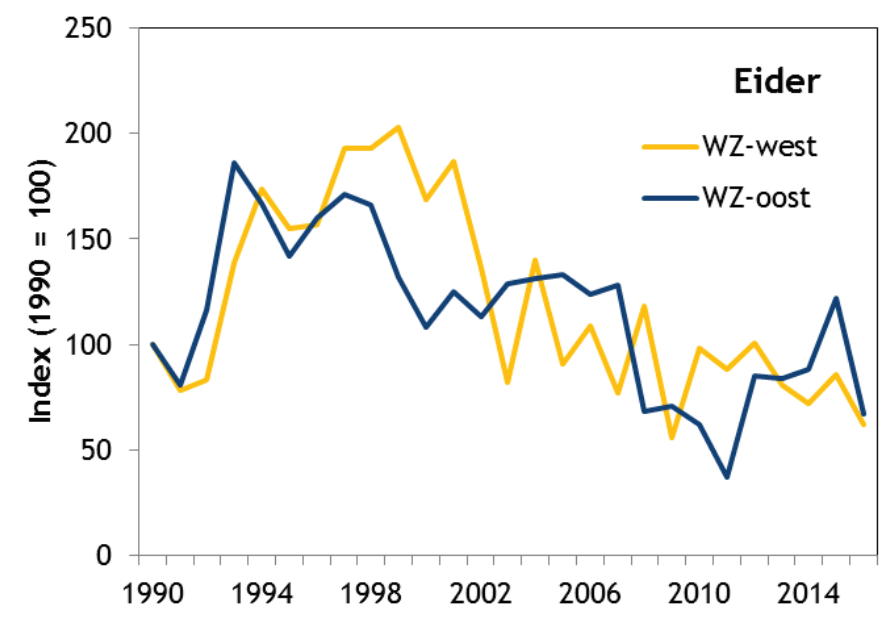

Figuur 4.3. Trends in aantallen broedparen Eiders in de Waddenzee (index), gesplitst naar Westelijke Waddenzee (west van wantij Terschelling) en oostelijke Waddenzee (tot Eemshaven) . Gegevens broedvogelmeetnet Sovon/CBS. [Trends in numbers of breeding pairs (expressed as index) for Common Eider in the western and eastern Wadden Sea.]

\section{Reproductie 2015}

In twee steekproefgebied op Vlieland werden in totaal 32 nesten gevolgd, waarvan 19 nesten succesvol werden uitgebroed (klassiek nestsucces hele steekproef 59,4\%). Van de mislukte nesten was predatie (door Bruine rat) de belangrijkste verliesoorzaak. Voor slechts vier gebieden waren kwalitatief goede jongentellingen beschikbaar. Deze leverden 0,07 (Vlieland), 0,14 (Griend), 0,42 (Ameland) en 1,70 (Texel) jong per vrouwtje op. 


\section{Reproductie 2016}

Op Vlieland kon slechts een kleine steekproef nesten worden gevolgd (14). Het klassieke nestsucces bedroeg $57,1 \%$ en was daarmee vergelijkbaar met 2015. Jongentellingen op Texel, Vlieland en Griend leverden resp. 1,68, 0,41 en 0,58 jong per vrouwtje op. De goede resultaten voor Texel in 2015 werden dus bevestigd in 2016 en werden ook in eerdere jaren opgemerkt.

\section{Ontwikkelingen sinds 2005 en discussie}

De reeks nestgegevens die vanaf 2007 is verzameld laat zien dat het nestsucces jaarlijks varieert, en ook nog eens fors kan verschillen tussen de verschillende steekproefgebieden (tabel 4.1). Voor heel Vlieland opgeteld blijkt dat maximaal de helft van de nesten succesvol is (2013-2014). In de meeste andere jaren ligt het nestsucces beneden de 30\%, zo ook in 2015 en 2016 . Eiders op Vlieland blijken gevoelig voor predatie door Bruine rat. Het is onbekend of dit ook geldt voor de andere eilanden. Indien de situatie op Vlieland model zou staan voor de andere broedgebieden in de Waddenzee, is het lage nestsucces een belangrijke oorzaak voor het gemiddeld lage broedsucces.

Dat broedsucces vertoont in de tijd geen significante trend (figuur 4.4). Hele slechte jaren, zoals in 2006 en 2007, kwamen recent niet voor, maar het broedsucces tendeert wel naar een lager niveau dan in de periode voor 2010. Uitgaande van 0,4 tot 1 jong per paar die nodig zou zijn voor een stabiele populatie is wel duidelijk dat het broedsucces van Eiders in de meeste jaren (vanaf 2011 jaarlijks) aan de lage kant is. Of de Nederlandse Eiders andere broedresultaten hebben als vogels die in de Duitse of Deense Waddenzee broeden is onbekend (slechts kleine aantallen buiten Nederlandse Waddenzee).

Tabel 4.1. Nestsucces van Eider op Vlieland. Weergegeven zijn nestsucces cijfers op basis van Mayfieldberekeningen. Cursieve cijfers geven klassiek nestsucces weer (in vergelijking met Mayfield doorgaans een overschatting van het nestsucces). [Nest success data for Eider per site and per year. Given are Mayfield figures (apparent nest success given in italics).]

\begin{tabular}{|l|r|r|r|r|r|r|r|r|r|r|r|}
\hline Gebied & 2006 & 2007 & 2008 & 2009 & 2010 & 2011 & 2012 & 2013 & 2014 & 2015 & 2016 \\
\hline Vlieland, Bomenland & & 8,4 & 22,9 & 33,7 & 84,5 & & & & & & \\
\hline Vlieland, Meeuwenduinen & & & & & 9,6 & 44,8 & & 67,21 & 73,3 & 34,3 \\
\hline Vlieland, Kroon's Polders & & & & & & 35,4 & 75 & 77,14 & 40,08 & 47,1 & 13,08 \\
\hline Vlieland, som & & 8,4 & 22,9 & 33,7 & 29,6 & 41,6 & 25,8 & 50,3 & 53,8 & 20,6 & 21,9 \\
\hline
\end{tabular}

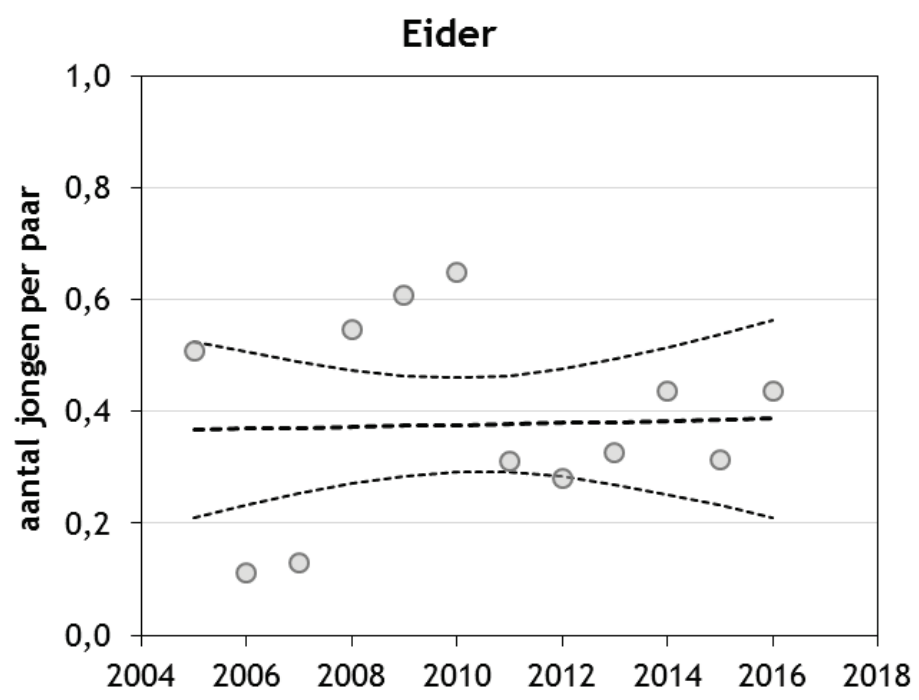

Figuur 4.4. Trend in broedsucces voor Eider voor de periode 2005-2016. De trend in broedsucces is onzeker ( $p=0,897)$. [Trend in breeding success (fledged young per pair) in Common Eider in the Dutch Wadden Sea in 2005-2016. No significant trend in breeding success could be detected.] 


\subsection{Scholekster Haematopus ostralegus - Eurasian Oystercatcher}

\section{Populatie en trend}

De Scholekster is één van de wijdst verspreide broedvogels in de Waddenzee, met hoge dichtheden op de kwelders en in de polders van de Waddeneilanden. Ten opzichte van 1990 nam het aantal broedparen in de Waddenzee met ruim de helft af (figuur 4.5). Deze afname betreft vooral de broedparen in de westelijke en oostelijke Waddenzee. De (kleine) broedpopulatie in de Eems-Dollard regio bleef lange tijd stabiel, maar neemt over de laatste tien jaar significant af (vooral na 2010 opvallende afname). In de westelijke Waddenzee stabiliseerde zich de populatie in de afgelopen tien jaar op een stabiel niveau. In de Waddenzee van Duitsland en Denemarken is sprake van een vergelijkbare afname als in onze Waddenzee, maar startte de negatieve trend later (na 2000) dan in de Nederlandse Waddenzee. De trend in de Waddenzee verloopt parallel aan de algehele negatieve ontwikkeling van de hele Nederlandse broedpopulatie, inclusief de Scholeksters die broeden in het boerenland in het binnenland.

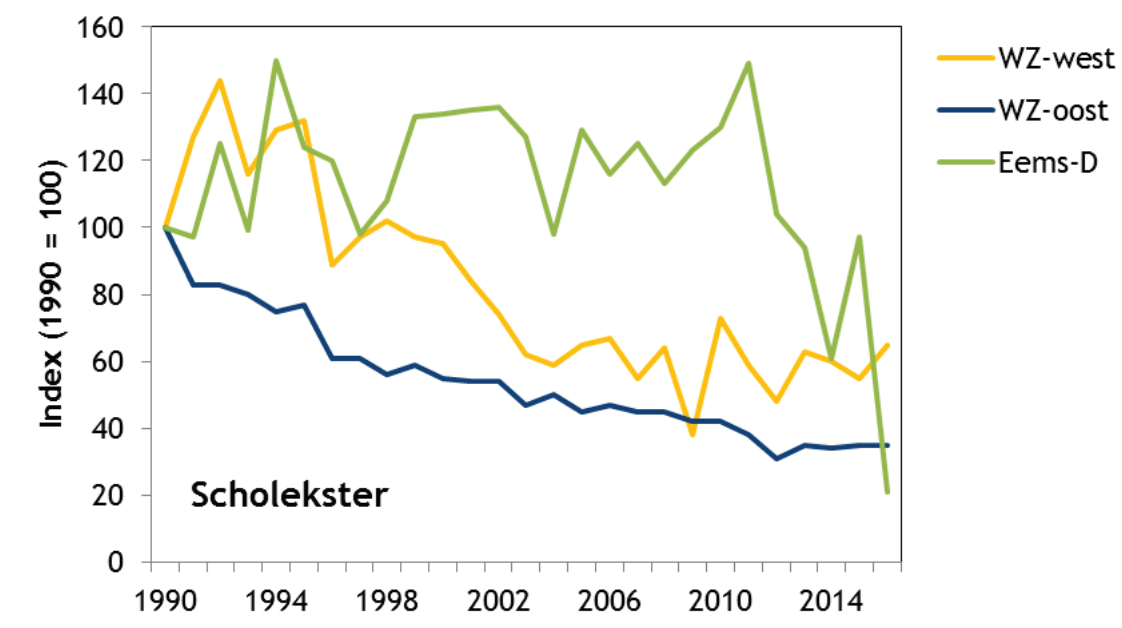

Figuur 4.5. Trends in aantallen broedparen Scholeksters in de Waddenzee (index), gesplitst naar Westelijke Waddenzee (west van wantij Terschelling), oostelijke Waddenzee (tot Eemshaven) en Eems-Dollard (Eemshaven-Dollard). Gegevens broedvogelmeetnet Sovon/CBS. [Trends in numbers of breeding pairs (expressed as index) for Eurasian Oystercatcher in the western, eastern Wadden Sea and Eems-Dollard estuary.]

\section{Reproductie 2015}

Op zeven locaties werden gegevens omtrent het nestsucces verzameld (klassieke uitkomstpercentages). Dit bedroeg gemiddeld $51,7 \%$. Nesten op de Buurdergrie/Ameland (97\%), de Schermdijk in de Haven van Delfzijl (72\%) en op het terrein van de Joost Dourleinkazerne/Texel $(77 \%)$ waren het meest succesvol. In De Petten en Kikkert, beide op Texel, waren nesten het minst succesvol (21\%).

Het uiteindelijke broedsucces, gemeten op negen locaties, varieerde van 0,0 tot 0,48 jong per paar. $\mathrm{Er}$ waren drie gebieden (Schermpier Haven Delfzijl, Banckspolder Schiermonnikoog, Vliehors/Vlieland) waar meer dan de 0,35 jong per paar vliegvlug werden die nodig worden geacht voor een stabiele populatie. Gebieden met weinig jongen lagen zowel op het vasteland (Balgzand, 0,18 jong/paar) als op de eilanden (Oosterkwelder Schiermonnikoog, 0,20 jong/paar). Niet overal waren duidelijke verliesoorzaken aan te geven. Predatie speelde op ten minste drie locaties een rol (twee gebieden op Texel en op het Balgzand).

\section{Reproductie 2016}

Het gemiddelde nestsucces (klassieke uitkomstpercentages), op basis van gegevens van zes locaties, was met $48 \%$, bijna vergelijkbaar met 2015. Opnieuw waren nesten op de Buurdergrie/Ameland het meest succesvol (82\%). Nesten in De Petten/Kikkert op Texel hadden nog minder succes (10\%) dan in 2015. 
In 12 gebieden werd het uiteindelijke broedsucces bepaald. Hiervan waren er drie (Lauwerpolder/ Groninger kust, Joost Dourleinkazerne/Texel, Ottersaat/Texel) waar in het geheel geen jongen werden grootgebracht. In de overige gebieden varieerde het broedsucces van 0,06 tot 0,60 jong per paar. In vijf van de 12 gebieden lag het aantal vliegvlugge jongen per paar rond, of boven het niveau waar de populatie geacht wordt voldoende jongen te produceren voor een stabiele populatie (Banckspolder en Oosterkwelder/Schiermonnikoog, Rottumerplaat, Klutenplas, Haven Delfzijl). Het broedsucces in 2016 was hoger dan in 2015, maar te laag in de context van een gezonde populatie.

\section{Ontwikkelingen sinds 2005 en discussie}

De Scholekster is één van de meest prominente broedvogels in de Waddenzee die een afname vertoont. Gaan we uit van de 0,35 jong per paar die jaarlijks nodig is om de populatie op peil te houden, dan wordt uit de gegevensreeks vanaf 2005 duidelijk dat Scholeksters in de afgelopen tien jaar over de hele Waddenzee bezien (gewogen gemiddelde) niet succesvol waren (figuur 4.3, rechts). Alleen lokaal zijn de broedresultaten soms beter. Waarnemingen tijdens broedvogelkarteringen langs onder meer de Groninger kust suggereren dat over grote regio's amper jongen worden grootgebracht. De trend in broedsucces sinds 2005 is stabiel, in dit geval dus 'stabiel slecht'. Jaren met een beter broedsucces vinden we vooral tot 1994 (figuur 4.6, links). In de meeste gevallen lijken paren al in de nestfase over de kop te gaan. Verliesoorzaken zijn niet altijd goed te kwantificeren, maar predatie (vooral vasteland) en overstromingen tijdens zomerstormen (vasteland en eilanden) worden het meest gemeld als oorzaak van mislukken. De magere broedresultaten in de Nederlandse Waddenzee komen overeen met de situatie in Duitsland en Denemarken.
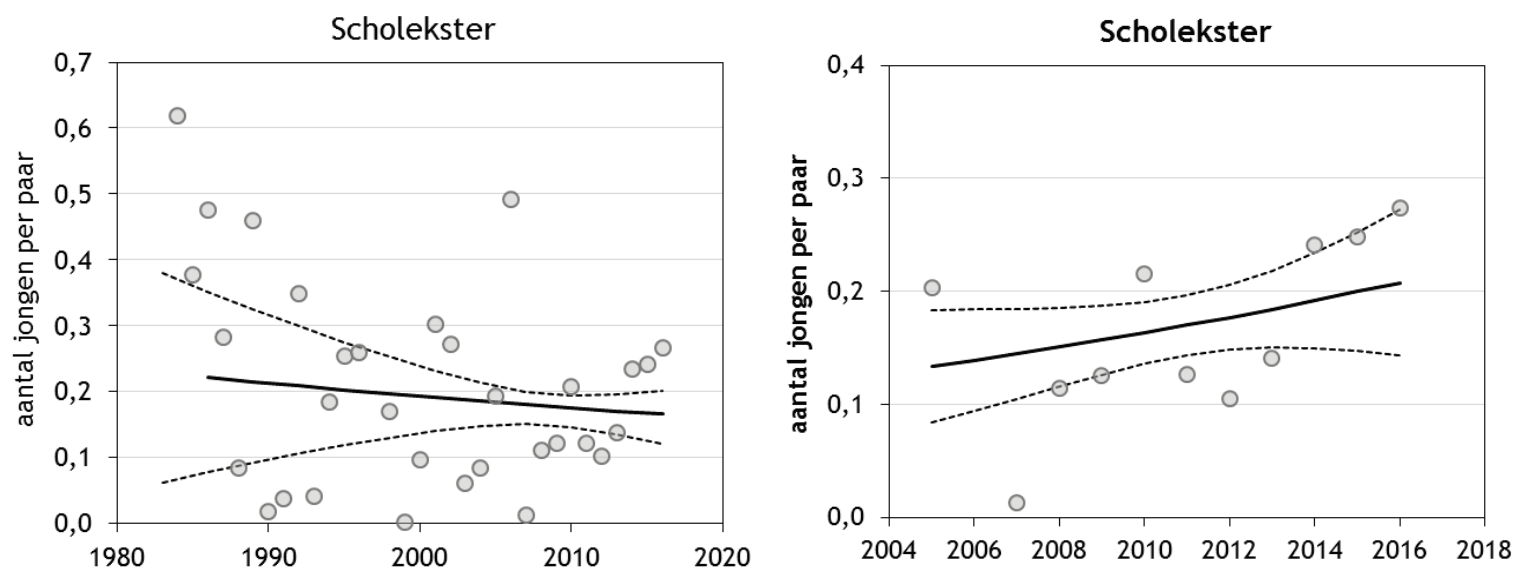

Figuur 4.6. Trend in broedsucces voor Scholekster, voor de periode 1983-2016 (links) en 2005-2016 (rechts). De trend in broedsucces is voor beide periodes stabiel (resp. $p=0,495$ en $p=0,154$ ). [Trend in breeding success (fledged young per pair) in Eurasian Oystercatcher in the Dutch Wadden Sea in 2005-2016. Trend for both periods is classified as stable.]

\subsection{Kluut Recurvirostra avosetta - Pied Avocet}

\section{Populatie en trend}

Kluten broeden in de Waddenzee vooral langs de Fries-Groningse kust, met slechts kleine aantallen op de eilanden. Het aantal broedparen in de hele Waddenzee nam sinds 1990 met gemiddeld 6\% per jaar af. In de oostelijke Waddenzee (waarin de belangrijke Friese en Groningse kwelders) was de afname veel sterker (gemiddeld $10 \%$ per jaar) dan in de westelijke Waddenzee ( $-5 \%)$. In de Eems-Dollard regio (voornamelijk Dollard) vertoont de trend sterke fluctuaties, maar is over de hele periode eveneens sprake van een sterke afname. Na 2010 lijkt de populatie zich te stabiliseren op een laag niveau (trend onzeker). Het gaat dan voor de hele Nederlandse Waddenzee om ongeveer een kwart van het aantal dat nog in het begin van de jaren negentig werd geteld (fig. 4.7). In de Waddenzee van Nedersaksen is het beeld vergelijkbaar, en na een aanvankelijk stabiele trend, nam het aantal in de belangrijke broedgebieden in Sleeswijk-Holstein recent ook af. De trend in de Nederlandse Waddenzee is negatiever dan de landelijke trend (die naast de Waddenzee vooral wordt gevoed door het Deltagebied). Het huidige aantal broedparen ligt ver onder de instandhoudingsdoelstellingen voor Natura 2000. 


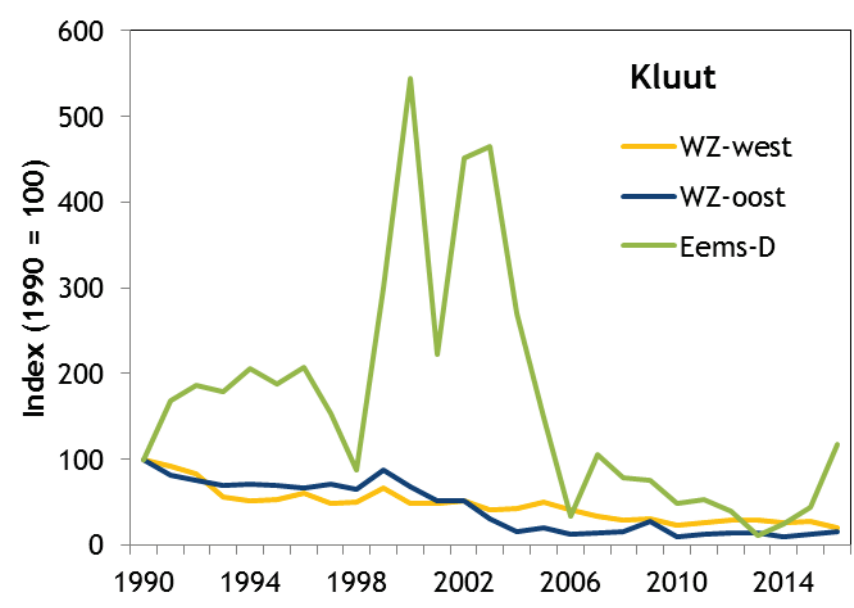

Figuur 4.7. Trends in aantallen broedparen Kluten in de Waddenzee (index), gesplitst naar Westelijke Waddenzee (west van wantij Terschelling), oostelijke Waddenzee (tot Eemshaven) en Eems-Dollard (Eemshaven-Dollard). Gegevens broedvogelmeetnet Sovon/CBS. [Trends in numbers of breeding pairs (expressed as index) for Pied Avocet in the western, eastern Wadden Sea and Eems-Dollard estuary.]

\section{Reproductie 2015}

Het nestsucces (Mayfield) dat op de Dollardkwelder en in de Klutenplas, beide aan de Groninger kust, werd vastgesteld bedroeg resp. 45,7 resp. 84,8\%. In het laatste, binnendijks gelegen gebied wordt met een elektrisch raster gewerkt om predatoren buiten de deur te houden (De Boer 2015). Het nestsucces op de Dollardkwelder was het hoogste in de hele reeks (tabel 4.2, merk op dat hier geen raster wordt gebruikt om predatoren te weren). Op de kwelder van de Negenboerenpolder bedroeg het klassieke nestsucces in een kleine steekproef (16 nesten) 30,4\%. Hier mislukten enkele nesten door vertrapping door vee. Indien mislukkingsoorzaken werden genoemd, kwam predatie het meest voor.

In twee van de zeven onderzoeksgebieden werd een redelijk aantal jongen grootgebracht, resp. 0,43 jong per paar op de Dollardkwelder en 0,40 jong per paar in de Klutenplas. Het gaat dan echter nog steeds om een broedsucces dat te laag is om de populatie in stand te houden. In de overige gebieden ging het om 0,0 tot 0,19 jong per paar. Over het geheel genomen zijn de broedresultaten te laag.

Tabel 4.2. Nestsucces van Kluut in de Waddenzee. Weergegeven zijn nestsucces cijfers op basis van Mayfield-berekeningen. Cursieve cijfers geven klassiek nestsucces weer (in vergelijking met Mayfield doorgaans een overschatting van het nestsucces). Cijfers in vet gedrukt zijn van locaties waar een elektrisch raster werd gebruikt om de nesten tegen predatie te beschermen. [Nest success data for Pied Avocet per site and per year. Given are Mayfield figures (apparent nest success given in italics). Figures printed in bold refer to colonies that had anti-predatation measures by an electrical fence.]

\begin{tabular}{|c|c|c|c|c|c|c|c|c|c|c|c|}
\hline Gebied & 2006 & 2007 & 2008 & 2009 & 2010 & 2011 & 2012 & 2013 & 2014 & 2015 & 2016 \\
\hline Dollardkwelder & 0,1 & 1,3 & & 0,4 & 0,2 & 0,2 & 9,3 & 7,1 & 7,0 & 45,7 & 17,6 \\
\hline Punt van Reide & & 66,7 & & & & & & & & & \\
\hline Polder Breebaart & & 74,8 & & 13,0 & & 0,6 & & & & & \\
\hline Noordpolderkwelder & & & & & & 2,3 & & & & & \\
\hline Klutenplas & & 0,0 & 62,6 & 67,4 & 54,8 & 11,0 & & 9,7 & 46,0 & 84,8 & 33,7 \\
\hline Negenboerenp.kwelder & & & & & & & & & 45,0 & 30,4 & \\
\hline Noorderleech & 58,5 & & & 18,5 & 16,4 & & & & & & \\
\hline Kwelder Ferwerd & 26,8 & & & & & & & & & & \\
\hline
\end{tabular}

\section{Reproductie 2016}

Gegevens van het nestsucces (Mayfield) laten zien dat nesten in 2016 minder succesvol waren dan in 2015. Ondanks een elektrisch raster wisten predatoren in de Klutenplas veel nesten te prederen. Voor zover kon worden nagegaan ging het om predatie door Vos (De Boer 2016). Het uiteindelijke nestsucces bedroeg er 33,7\%. Op de Dollardkwelder was het nestsucces 17,6\% (zie tabel 4.2). Ook hier 
was predatie een belangrijke verliesoorzaak, maar om welke predatoren het ging kon niet met zekerheid worden vastgesteld.

Het uiteindelijke broedsucces was in zes van de negen gebieden minder dan 0,1 jong per paar, waaronder vijf van de zes (kleine) kolonies op Texel. Paren in de Kroon's Polders op Vlieland (25) waren relatief succesvol (0,44 jong/paar). In de Klutenplas kwamen ondanks alle nestverliezen nog 0,24 jongen per paar groot. In alle gebieden is het broedsucces (veel) te laag.

\section{Ontwikkelingen sinds 2005 en discussie}

Over de hele reeks vanaf 2005 bekeken stak het broedsucces in 2015 en 2016 gunstig af bij de broedresultaten uit eerdere jaren (figuur 4.8). Er is echter sprake van sterke jaarlijkse fluctuaties, die leiden tot een onzekere trend. De gewogen gemiddeldes voor de hele Waddenzee maken duidelijk dat Kluten in de hele periode 2005-2016 minder jongen produceren dan de 0,5-1,0 jong per paar die nodig is voor behoud van een ten minste stabiele populatie. Veel paren mislukken in de nestfase (tabel 4.2). Predatiewerende maatregelen (elektrisch raster) verhogen de kans op succesvolle nesten, maar zijn geen garantie voor een hoog nestsucces (zie o.a. Noordpolderkwelder in 2011, Klutenplas in 2011 en 2016). Opvallend is bovendien dat ook in gebieden met een hoger nestsucces er uiteindelijk heel weinig jongen vliegvlug worden. De kuikenfase lijkt dus een kritieke periode, maar het is niet duidelijk waarom zo weinig kuikens overleven (voedsel, weersomstandigheden, predatie?).

Zowel nestsucces als broedsucces passen goed bij gegevens die in 2009-2012 in de Duitse Waddenzee werden verzameld. Daar werd in 18 van de 20 combinaties van jaar x gebied een broedsucces van minder dan 0,20 jong per paar gerapporteerd. Het nestsucces lag in dezelfde orde van grootte (met zelfde variatie in ruimte en tijd) als in de Nederlandse Waddenzee.

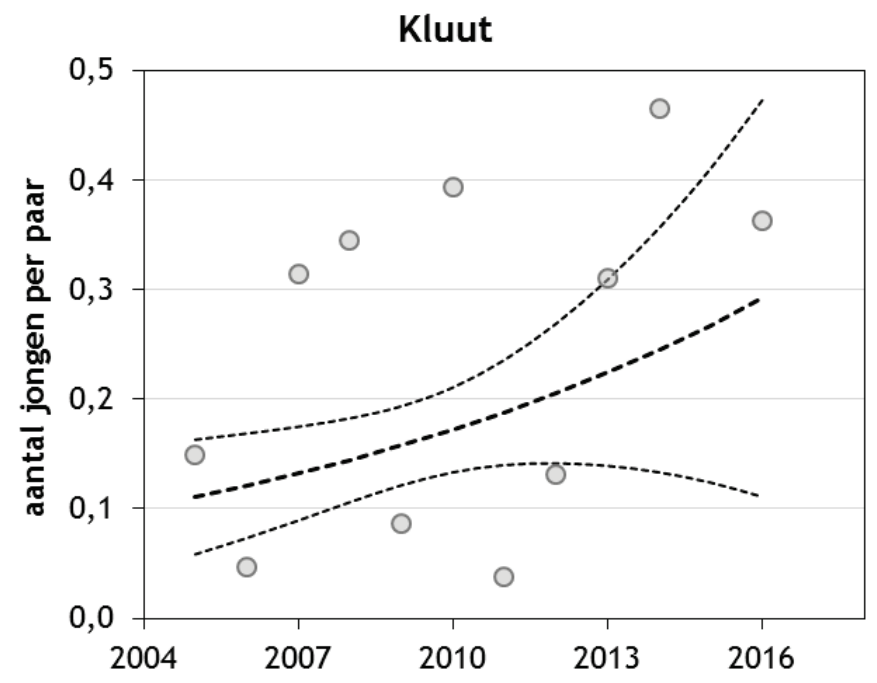

Figuur 4.8. Trend in broedsucces voor Kluut, voor de periode 2005-2016. De trend in broedsucces is onzeker ( $p=0,061)$. [Trend in breeding success (fledged young per pair) in Pied Avocet in the Dutch Wadden Sea in 2005-2016. No significant trend in breeding success could be detected.]

\subsection{Kokmeeuw Chroicocephalus ridibundus - Black-headed Gull}

\section{Populatie en trend}

De broedpopulatie in de Waddenzee is sterk geconcentreerd op Griend in de westelijke Waddenzee (in 2015 en 2016 resp. 24.403 en 19.392 paren). Het aantal broedparen in de hele Waddenzee in 2016 is meer dan gehalveerd ten opzichte van 1990, vooral door een duidelijke afname in de oostelijke Waddenzee na 2000 (figuur 4.9). Veel broedkolonies concentreren zich tegenwoordig op de eilanden. De afname in de Nederlandse Waddenzee staat deels op zichzelf. Alleen in Nedersaksen wordt een vergelijkbare ontwikkeling gemeld, terwijl in Sleeswijk-Holstein de soort in de lift zit (trend Denemarken onzeker, maar tendens toenemend). 


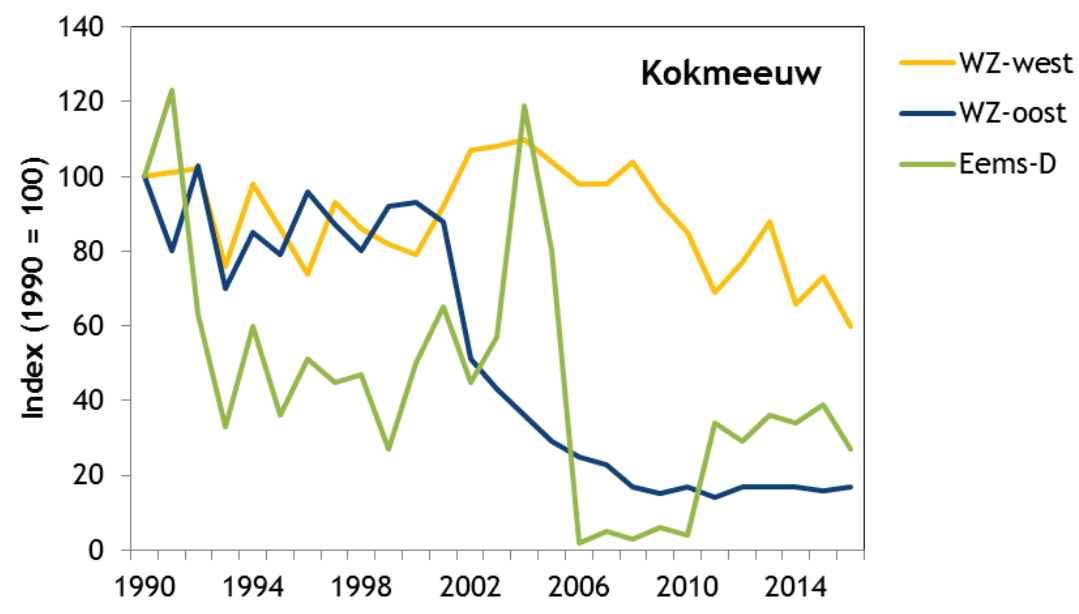

Figuur 4.9. Trends in aantallen broedparen Kokmeeuwen in de Waddenzee (index), gesplitst naar Westelijke Waddenzee (west van wantij Terschelling), oostelijke Waddenzee (tot Eemshaven) en EemsDollard (Eemshaven-Dollard). Gegevens broedvogelmeetnet Sovon/CBS. [Trends in numbers of breeding pairs (expressed as index) for Black-headed Gull in the western, eastern Wadden Sea and Eems-Dollard estuary.]

\section{Reproductie 2015}

Nesten werden alleen intensief gevolgd op het 'sterneneiland' in de Haven van Delfzijl (bij Oterdum). Het nestsucces, gemeten met Mayfield, bedroeg hier 64,2\% (klassiek: 70\%). Nesten op de schermdijk van de Haven van Delfzijl, op de Oosterkwelder van Schiermonnikoog en in de Klutenplas aan de Groninger kust werden minder intensief gevolgd, maar waren in geen enkel geval succesvol. In de kleine kolonie in De Petten op Texel kwam de helft van alle nesten uit. Nestverliezen op de Schermdijk in Delfzijl, in de Klutenplas en op Texel werden vooral door predatie veroorzaakt. De aard van predatie was divers: Bruine rat in Delfzijl, Vos in de Klutenplas en Zilvermeeuw op Texel.

In vijf van de acht onderzochte kolonies kwam uiteindelijk (vrijwel) geen enkel jong groot, waaronder ook de grote vestiging op Griend (0,04 jong/paar). Alleen de kolonies in de Eemshaven (0,90 jong per paar) en op het 'sterneneiland' bij Oterdum $(0,77$ jong per paar) waren ten minste gedeeltelijk succesvol. In beide gevallen gaat het om kolonies die moeilijk toegankelijk zijn voor landpredatoren. Ook de kolonies die gedeeltelijk succesvol waren produceerden nog te weinig jongen voor een stabiele populatie.

\section{Reproductie 2016}

Het nestsucces op het 'sterneneiland' bij Oterdum was met 87,6\% (Mayfield, klassiek 90\%) hoger dan in 2015. In de naburige kolonie op de Schermdijk in de Haven van Delfzijl mislukten alle nesten door predatie door Bruine rat.

In vijf van de negen kolonies was het broedsucces nihil. De kolonie op Griend was succesvoller dan in 2015, maar presteerde met 0,13 jongen per paar nog steeds ver onder de maat. Kolonies in Ottersaat/Texel, de kwelder van Hollum/Ameland en die van het 'sterneneiland' bij Oterdum leverden resp. 0,48, 0,63 en 0,70 jong per paar op (laatste kolonie dus vergelijkbaar met 2015). In geen enkel geval leverden de onderzochte kolonies de benodigde reproductie om het aantal op peil te houden. Verliezen in Ottersaat kwamen vooral door predatie door Bruine rat. Bij Oterdum werd het broedsucces verminderd door slecht weer.

\section{Ontwikkelingen sinds 2005 en discussie}

Vooral de lange termijn reeks vanaf 1995 maakt duidelijk dat Kokmeeuwen in de jaren na 2010 uitermate slecht presteerden (2014 uitzondering op de regel). Zowel vanaf 1995 als vanaf 2005 is ook sprake van een significante afname (figuur 4.10). Als we uitgaan van ongeveer 1 jong per paar dat nodig is voor een stabiele populatie is ook duidelijk dat Kokmeeuwen recent (veel) te weinig jongen grootbrengen. De gegevensreeks (vooral lange termijn) wordt sterk gedomineerd door de situatie op Griend, maar het grotendeels verdwijnen van kokmeeuwenkolonies langs de vastelandskusten van Noord-Holland, Friesland en Groningen na 2000 (vooral gevolg van predatie, Bos et al. 2015) heeft 
deze kolonie in een Waddenzee-brede context tot veruit de belangrijkste vestiging gemaakt. De oorzaken voor het magere broedsucces is niet altijd duidelijk. De slechte broedresultaten op Griend worden geweten aan slechte voedselomstandigheden (Lutterop \& Kasemir 2015, 2016).

De Nederlandse gegevens passen goed bij het beeld dat in 2009-2012 in de Waddenzee in Nedersaksen werd verkregen. Alleen in Sleeswijk-Holstein (waar ook de populatie groeit) was het broedsucces beter.
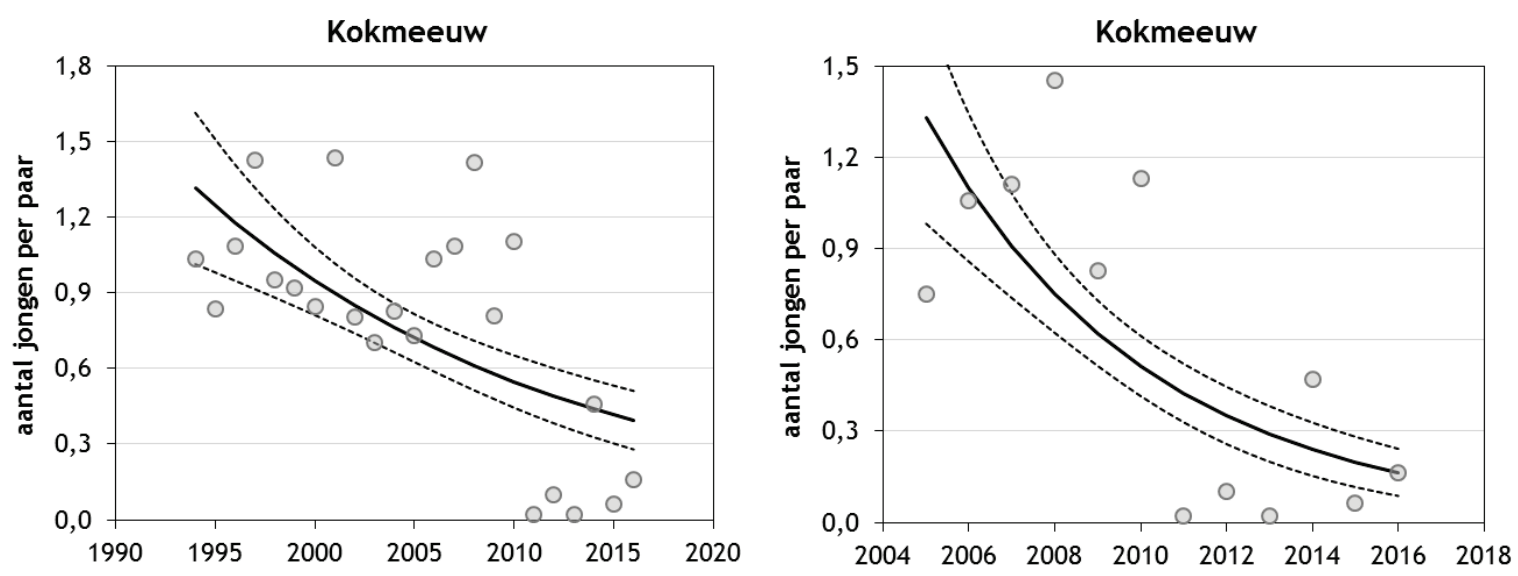

Figuur 4.10. Trend in broedsucces voor Kokmeeuw, voor de periode 1995-2016 (links) en 2005-2016 (rechts). De trend in broedsucces vertoont over 1995-2016 een sterke afname ( $p<0,001)$, resp. een matige afname voor 2005-2016 ( $p<0,001)$. [Trend in breeding success (fledged young per pair) in Black-headed Gull in the Dutch Wadden Sea in 1995-2016 and 2005-2016. For both periods a significant decline in breeding success was recorded.]

\subsection{Kleine Mantelmeeuw Larus fuscus - Lesser Black- backed Gull}

\section{Populatie en trend}

Kleine Mantelmeeuwen broeden voornamelijk in de duinen van de Waddeneilanden. Hun aantallen namen sinds 1990 significant toe, maar vertonen de laatste tien jaar tekenen van stabilisatie (overeenkomstig de landelijke trend, incl. Deltagebied; zie figuur 4.11). De afname in de westelijke Waddenzee na 2014 is met voorzichtigheid te interpreteren, aangezien de volledigheid van de tellingen op Texel en Terschelling te wensen overlaat en schattingen voor ontbrekende kolonies met grote onzekerheden zijn omgeven. In de Waddenzee van Nedersaksen en Sleeswijk-Holstein is het aantalsverloop grotendeels vergelijkbaar met dat in Nederland, terwijl de kleine aantallen in de Deense Waddenzee nog steeds een toenemende tendens vertonen (zij het met fluctuaties). Gezien de stabilisatie ligt het aantal vermoedelijk in dezelfde orde van grootte (ruim 50.000 paren) als bij de laatste complete telling in 2012. Voor het Natura 2000-gebied Waddenzee liggen de aantallen momenteel rond de geformuleerde instandhoudingsdoelstelling voor Natura 2000. In de duinen van Texel en Vlieland liggen ze er boven.

\section{Reproductie 2015}

Het nestsucces, gemeten naar zowel de klassieke benadering als met behulp van de Mayfield-methode lag in 2015 in de westelijke Waddenzee (Texel, Vlieland) hoger dan in de oostelijke Waddenzee (Rottumerplaat)(tabel 4.3). Het uiteindelijke broedsucces varieerde van 0,41 tot 0,58 jong per paar (Schiermonnikoog, twee kolonies op Texel en Vlieland) - alleen Rottumerplaat zat daar duidelijk boven met 1,2 jong per paar. Ondanks het lagere nestsucces was deze kolonie in de kuikenfase dus succesvoller dan de andere vier kolonies. 


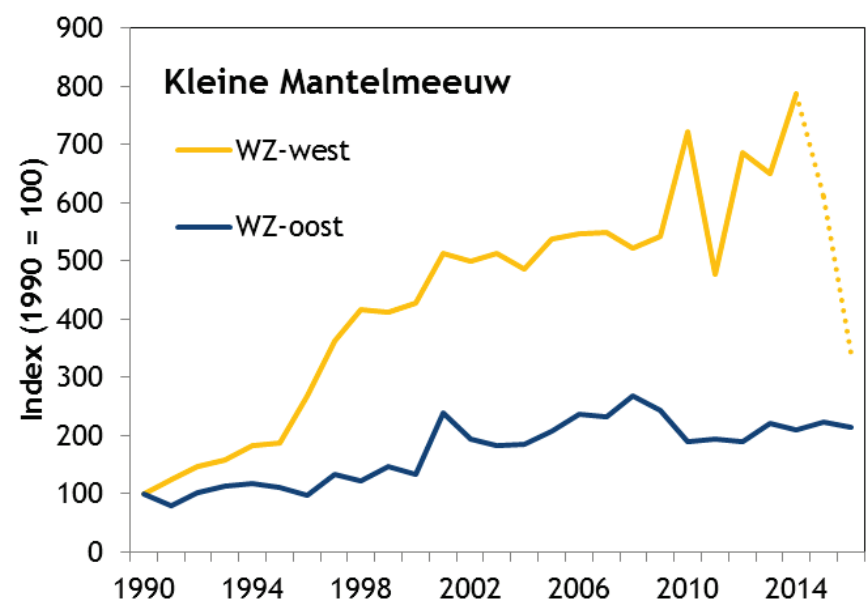

Figuur 4.11. Trends in aantallen broedparen Kleine Mantelmeeuwen in de Waddenzee (index), gesplitst naar Westelijke Waddenzee (west van wantij Terschelling) en oostelijke Waddenzee (tot Eemshaven) . Gegevens broedvogelmeetnet Sovon/CBS. Periode 2014-2016 onzeker in verband met lage teldekking en groot aandeel bijgeschatte kolonies. [Trends in numbers of breeding pairs (expressed as index) for Lesser Back-backed Gull in the western and eastern Wadden Sea.Note low coverage (and high amount of estimated data) in 2014-2016 which may result in less reliable trend.]

\section{Reproductie 2016}

Van de enige kolonie waar tijdig nestgegevens van beschikbaar waren (die van de Vliehors op Vlieland) lag het nestsucces lager dan in 2015 (tabel 4.3). Zowel op Vlieland als op Texel (Kelderhuispolder) was het uiteindelijke broedsucces heel vergelijkbaar met 2015 (resp. 0,43 en 0,57 jong per paar). De twee onderzochte kolonies in de oostelijke Waddenzee waren succesvoller: Schiermonnikoog met 0,9 jong per paar en Rottumerplaat met 1,0 jong per paar.

Tabel 4.3. Nestsucces van Kleine Mantelmeeuw in de Waddenzee. Weergegeven zijn nestsucces cijfers op basis van Mayfield-berekeningen. Cursieve cijfers geven klassiek nestsucces weer (in vergelijking met Mayfield doorgaans een overschatting van het nestsucces). Gegevens Texel/Kelderhuispolder zijn verzameld door Kees Camphuysen/NIOZ. [Nest success data for Lesser Black-backed Gull per site and per year. Given are Mayfield figures (apparent nest success given in italics).]

\begin{tabular}{|l|r|r|r|r|r|r|r|r|r|r|r|}
\hline Gebied & 2006 & 2007 & 2008 & 2009 & 2010 & 2011 & 2012 & 2013 & 2014 & 2015 & 2016 \\
\hline Texel, Kelderhuispolder & 61,0 & 78,0 & 73,0 & 77,0 & 84,0 & 71,0 & 68,0 & 54,0 & 86,0 & & \\
\hline Texel, Westerduinen & & & & & 71,0 & 100,0 & 57,0 & 100,0 & 68,0 & 83,0 & \\
\hline Vliehors, Middelste stuifdijk & 66,5 & 67,6 & 67,7 & 65,8 & 57,0 & 47,6 & 61,0 & 85,2 & 94,4 & 66,5 \\
\hline Rottumerplaat & & & & & & 81,0 & 88,7 & & & 61,5 & \\
\hline Schiermonnikoog & & & & & & & & & 63,7 & & \\
\hline
\end{tabular}

\section{Ontwikkelingen sinds 2005 en discussie}

Het nestsucces van Kleine Mantelmeeuw vertoont jaarlijkse variatie, maar geen duidelijke tendens voor een toe- of afname. Of het verschilt binnen de Waddenzee laat zich uit de schaarse gegevens van de oostelijke Waddenzee moeilijk afleiden. In 2014 en 2015 leken nesten op Schiermonnikoog en op Rottumerplaat minder succesvol dan die op Vlieland en Texel, maar in 2011-2012 was het juist andersom. Met de structurele uitbreiding van het meetnet op Schiermonnikoog wordt dit beeld in de komende jaren wellicht duidelijker.

Het broedsucces in 2015-2016 (gerekend naar gewogen gemiddeldes, figuur 4.12) stak gunstig af bij voorgaande jaren. Over de hele gegevensreeks vanaf 2005 is sprake van een significante toename van het broedsucces. Deels (2010-2011, 2014) liggen ze bovendien binnen de bandbreedte van broedsucces die nodig wordt geacht voor een stabiele populatie (meer dan 0,6 jong per paar), zij het dat dit mogelijk teniet wordt gedaan door eventuele veranderingen in de jaarlijkse overleving. Daar waar het broedsucces lager is, lijkt de kuikenperiode de kritieke fase. Problemen in de voedselvoorziening, onder andere veroorzaakt door veranderingen in visserijbeleid (gesloten gebieden, afname discards) zijn hiervoor de meest aannemelijke oorzaken (o.a. Camphuysen 2013). 


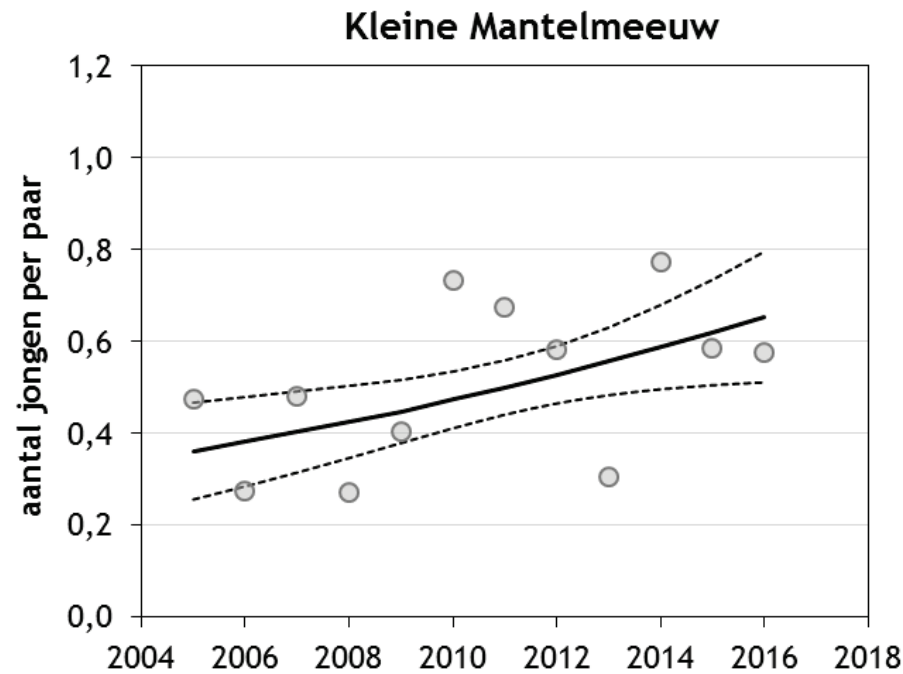

Figuur 4.12. Trend in broedsucces voor Kleine Mantelmeeuw voor de periode 2005-2016. De trend in broedsucces vertoont een matige toename $(p=0,016)$. [Trend in breeding success (fledged young per pair) in Lesser Black-backed Gull in the Dutch Wadden Sea in 2005-2016. A significant increase in breeding success was recorded.]

In 2009-2012 was het broedsucces in de internationale Waddenzee het hoogste in Nedersaksen en Denemarken, het laagste in Nederland en Sleeswijk-Holstein. Hoe zich deze verhoudingen recent hebben ontwikkeld is nog niet duidelijk.

\subsection{Zilvermeeuw Larus argentatus - Herring Gull}

\section{Populatie en trend}

Anders dan Kleine Mantelmeeuw namen zilvermeeuwen in de Waddenzee sinds 1990 overal af met gemiddeld $3 \%$ per jaar (westelijke en oostelijke Waddenzee vergelijkbaar). In de westelijke Waddenzee stabiliseerde de trend in de afgelopen tien jaar (figuur 4.13). Voor de hele Waddenzee resteerde in 2016 nog ongeveer een derde van de populatie Zilvermeeuw die in 1990 werd geteld. Vergelijkbaar is het aantalsverloop in de Waddenzee van Nedersaksen (in mindere mate ook in Sleeswijk-Holstein), terwijl de Deense broedvogels in de lift zitten.

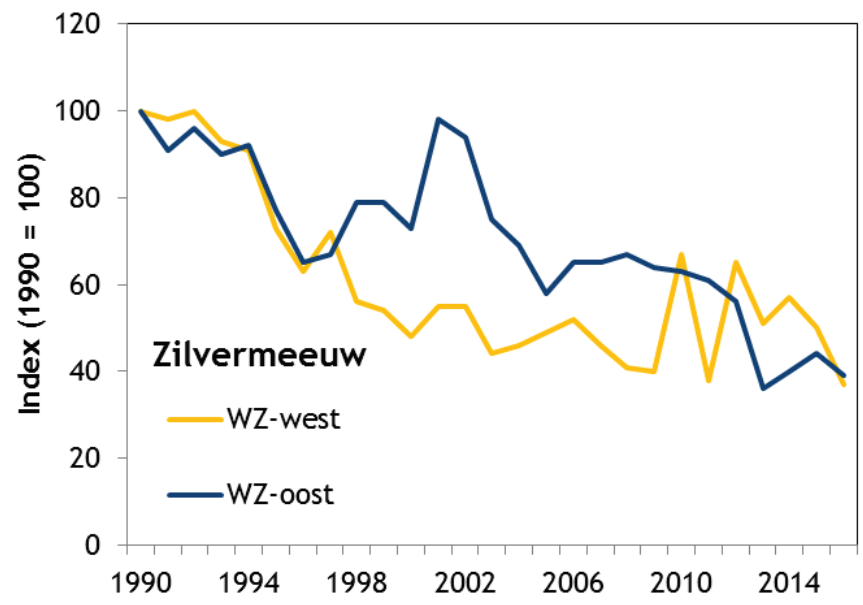

Figuur 4.13. Trends in aantallen broedparen Zilvermeeuwen in de Waddenzee (index), gesplitst naar Westelijke Waddenzee (west van wantij Terschelling) en oostelijke Waddenzee (tot Eemshaven). Gegevens broedvogelmeetnet Sovon/CBS. [Trends in numbers of breeding pairs (expressed as index) for Lesser Backbacked Gull in the western and eastern Wadden Sea.] 


\section{Reproductie 2015}

De nesten die in twee kolonies (Texel, Vlieland) in 2015 zijn gevolgd, waren met een nestsucces van meer dan 90\% zeer succesvol (tabel 4.4). Het uiteindelijke broedsucces was alleen op Vlieland goed (1,22 jong per paar). In de kolonies op Rottumerplaat ( 0,60 jong per paar), Kelderhuispolder/Texel $(0,64$ jong per paar), Schiermonnikoog $(0,54$ jong per paar) en Westerduinen/Texel $(0,28)$ was het broedsucces beduidend lager.

\section{Reproductie 2016}

Net als bij Kleine Mantelmeeuw was het nestsucces in 2016 lager, voor de enige kolonie waar in beide jaren gegevens werden verzameld (tabel 4.4). Het broedsucces was daarentegen in 2016 beter dan in 2015. Kolonies op Rottumerplaat $(1,00)$ en Vlieland $(1,05)$ brachten meer dan één jong per paar groot, die van Schiermonnikoog 0,90. Alleen de Kelderhuispolder op Texel bleef wat achter, met een vergelijkbaar broedsucces als in 2015 (0,67 jong per paar).

Tabel 4.4. Nestsucces van Zilvermeeuw in de Waddenzee. Weergegeven zijn nestsucces cijfers op basis van Mayfield-berekeningen. Cursieve cijfers geven klassiek nestsucces weer (in vergelijking met Mayfield doorgaans een overschatting van het nestsucces). Gegevens Texel/Kelderhuispolder zijn verzameld door Kees Camphuysen/NIOZ. [Nest success data for Herring Gull per site and per year. Given are Mayfield figures (apparent nest success given in italics).]

\begin{tabular}{|l|r|r|r|r|r|r|r|r|r|r|r|}
\hline Gebied & 2006 & 2007 & 2008 & 2009 & 2010 & 2011 & 2012 & 2013 & 2014 & 2015 & 2016 \\
\hline Texel, Kelderhuispolder & 80,0 & 64,0 & 68,0 & 70,0 & 82,0 & 65,0 & 71,0 & 65,0 & 85,0 & & \\
\hline Texel, Westerduinen & 85,0 & & & & 95,0 & 87,0 & 83,0 & 94,0 & 90,0 & 90,0 & \\
\hline Vliehors, Middelste stuifdijk & & 75,0 & 86,4 & 67,1 & 62,0 & 54,4 & 55,3 & 39,1 & 86,6 & 93,3 & 65,9 \\
\hline Rottumerplaat & & & & & & 100,0 & 92,3 & & & 51,3 \\
\hline Schiermonnikoog & & & & & & & & & 81,5 & \\
\hline Noorderleech & 0,3 & & & & & & & & & \\
\hline
\end{tabular}

\section{Ontwikkelingen sinds 2005 en discussie}

Net als bij Kleine Mantelmeeuw is er een hoge mate van variatie in nestsucces over de jaren, en ook binnen de Waddenzee. In 2011-2012 was de kolonie op Rottumerplaat succesvoller dan die elders in de Waddenzee, maar in 2016 was het net andersom. De enige kolonie op het vasteland waar gegevens van beschikbaar waren (Noorderleech, Friesland buitendijks) suggereert dat vastelandkolonies weinig succesvol zijn. Daar waar Zilvermeeuwen op het vasteland broeden (vooral industrieterrein Delfzijl) doen de meesten dat op daken van gebouwen en installaties, buiten het bereik van grondpredatoren. De nestsucces-gegevens verzameld in 2005-2016 passen verder goed in de reeks uit eerdere jaren.

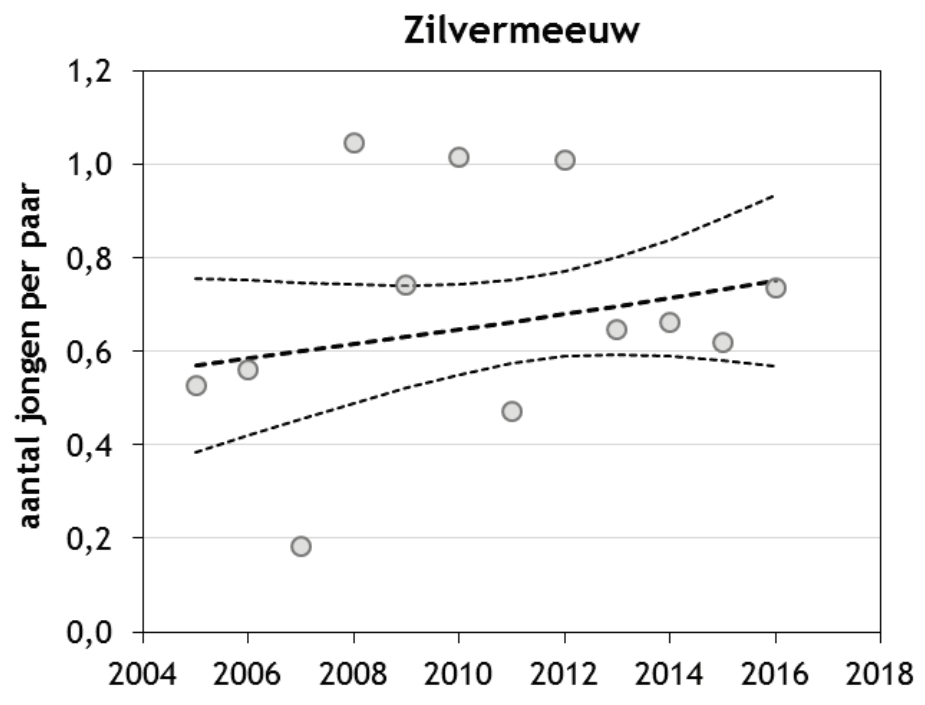

Figuur 4.14. Trend in broedsucces voor Zilvermeeuw voor de periode 2005-2016. De trend in broedsucces is onzeker ( $p=0,293)$. [Trend in breeding success (fledged young per pair) in Herring Gull in the Dutch Wadden Sea in 2005-2016. No significant trend in breeding success was recorded.] 
Het broedsucces in 2015-2016 was heel vergelijkbaar met gegevens verzameld in 2013-2014, maar lag op een wat lager niveau dan in de periode rond 2010 (figuur 4.14). Er is evenwel geen significante trend in broedsucces over de periode 2005-2016 zichtbaar. In de meeste jaren vanaf 2008 lijken Zilvermeeuwen voldoende succesvol om ten minste een stabiele populatie mogelijk te maken $(>0,6$ jong per paar), zij het dat 2013-2016 dit slechts nipt halen, en eventuele veranderingen in jaarlijkse overleving dan belangrijk zijn. Gegevens van de Kelderhuispolder wijzen er op dat de jaarlijkse overleving van Zilvermeeuwen aan de lage kant is (Camphuysen 2013, Van der Jeugd et al. 2014). In combinatie met de lagere overleving is het recente broedsucces wellicht toch te weinig voor een stabiele populatie. Deze ontwikkeling verklaart waarschijnlijk ook de aanhoudend negatieve trend in het aantal broedende Zilvermeeuwen in de hele Waddenzee.

\subsection{Grote Stern Sterna sandvicensis - Sandwich Tern}

\section{Populatie en trend}

Het aantal in de Waddenzee broedende Grote Sterns schommelt sinds 2007 tussen de 10.000 en 12.000 paren (uitgezonderd een inzinking in 2012-2013) (figuur 4.15). De verspreiding in 2015-2016 was beperkt tot 4-5 kolonies, alle gelegen op de Waddeneilanden. In de afgelopen tien jaar verspreidden de sterns zich vanuit de grote kolonie op Griend naar Ameland en Texel, waar nu de grootste aantallen voorkomen. De broedpopulatie van de Waddenzee heeft zich nog niet hersteld van de afname die in de jaren zestig plaatsvond, zodat het huidige aantal niet in de buurt komt van de geformuleerde instandhoudingsdoelstellingen voor het Natura 2000-gebied Waddenzee. Tegenover de overwegend stabiele aantallen in de Nederlandse Waddenzee staan afnames in Sleeswijk-Holstein en Denemarken. In Nedersaksen fluctueren de aantallen van jaar op jaar maar is geen uitgesproken negatieve of positieve trend te bespeuren.

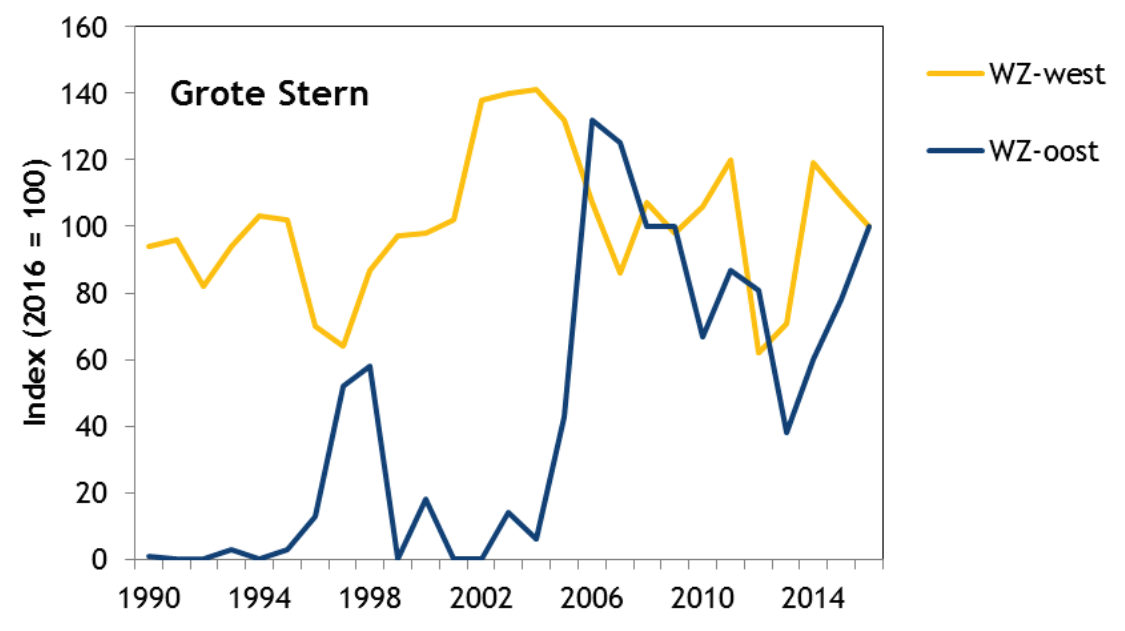

Figuur 4.15. Trends in aantallen broedparen Grote Sterns in de Waddenzee (index), gesplitst naar Westelijke Waddenzee (west van wantij Terschelling) en oostelijke Waddenzee (tot Eemshaven). Gegevens broedvogelmeetnet Sovon/CBS. [Trends in numbers of breeding pairs (expressed as index) for Sandwich Tern in the western and eastern Wadden Sea.]

\section{Reproductie 2015}

Van Grote Sterns worden geen nestgegevens verzameld. Het broedsucces in 2015 werd op drie locaties gemeten. De binnendijkse kolonie in het Wagejot op Texel was het meest succesvol $(1,15$ jong per paar). Op Griend (enclosure, 0,23 jong per paar) en op de kwelder van Hollum (0,43 jong per paar) waren de Grote Sterns minder succesvol.

\section{Reproductie 2016}

Opnieuw waren de binnendijkse Texelse kolonies succesvoller dan die op Griend en Ameland. Op Texel werden in het Wagejot en in Utopia resp. 0,79 en 0,80 jongen per paar grootgebracht. Op Ameland (kwelder Hollum) en Griend was het broedsucces vergelijkbaar met 2015 (resp. 0,48 en 0,27 jong per paar). 


\section{Ontwikkelingen sinds 2005 en discussie}

Het broedsucces tendeert zowel sinds 1991 als 2005 naar een afname, maar door de sterke jaarlijkse variatie is de trend onzeker. De resultaten van 2015-2016 waren vergelijkbaar met die in 2013-2014. Hoewel niet helemaal duidelijk is wat het benodigde broedsucces is voor een stabiele populatie, ligt die vanaf 2011 zeker op een te laag niveau ( $<0,4$ jong per paar), als we uitgaan van het niveau bij nauw verwante soorten. Het grote betrouwbaarheidsinterval wijst er ook op dat binnen de Waddenzee grote verschillen in broedsucces bestaan. Zowel in 2015 als 2016 waren de binnendijkse kolonies op Texel, waar recent de aantallen groeiden, succesvoller dan die op Griend en Ameland. Het gewogen gemiddelde van alle kolonies ligt dan echter toch op een laag niveau. Het voordeel van de Texelse kolonies, naast hun gunstige ligging ten opzichte van voedselgebieden op de Noordzee, is dat ze niet gevoelig zijn voor zomerse stormvloeden.
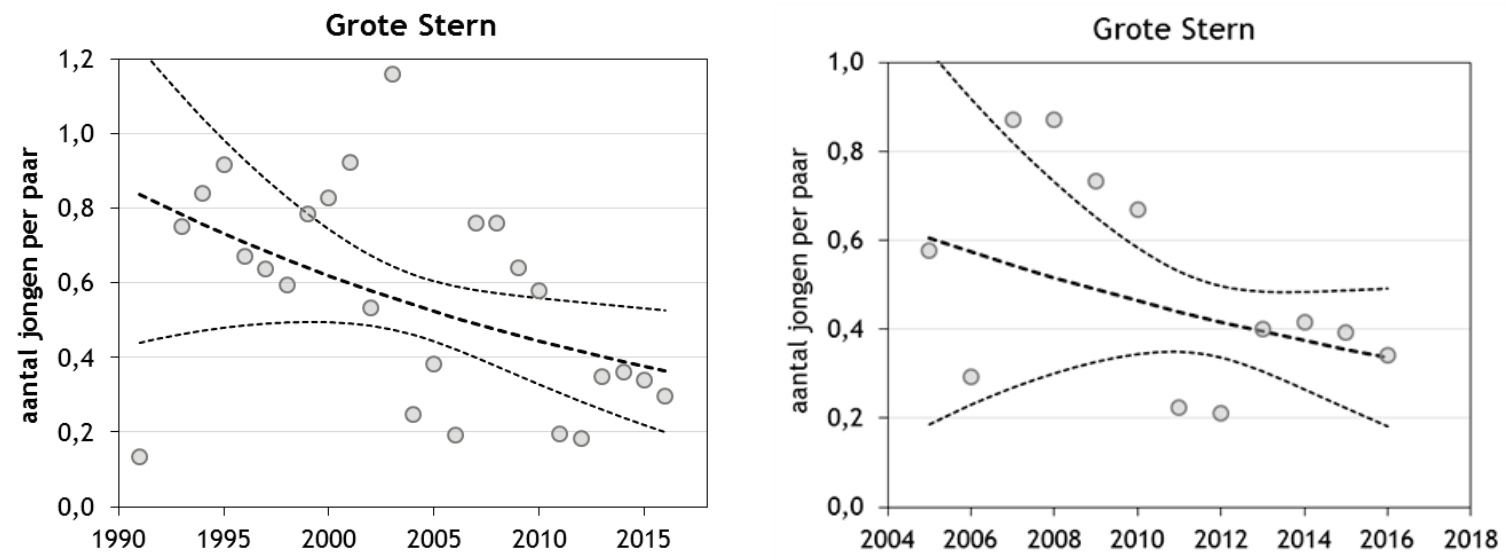

Figuur 4.16. Trend in broedsucces voor Grote Stern voor de periode 1991-2016 (linker paneel) en 20052016 (rechter paneel). De trend in broedsucces is voor beide periodes onzeker (resp. $p=0,068$ en 0,298). [Trend in breeding success (fledged young per pair) in Sandwich Tern in the Dutch Wadden Sea in 19912016 and 2005-2016. No significant trend in breeding success was recorded.]

\subsection{Visdief Sterna hirundo - Common Tern}

\section{Populatie en trend}

Het aantal broedende Visdieven in de Waddenzee is sinds 1990 ongeveer gehalveerd (figuur 4.17). De afname in de Waddenzee is sterker dan landelijk en lijkt ook sterker dan in de Duitse en Deense Waddenzee (trends door fluctuaties niet overal even duidelijk). In de oostelijke Waddenzee was de trend ook in de afgelopen tien jaar nog significant negatief (hele Waddenzee en andere delen onzeker).

Veel kolonies zijn gehuisvest op de eilanden (grootste op Griend). Grote kolonies op het vasteland zijn sterk geconcentreerd op enkele locaties, waarvan die in de Eemshaven in 2016 de grootste was (565 paar, grootste kolonie 2015839 paar op Griend). De vestiging in de Eemshaven is waarschijnlijk tijdelijk van aard, omdat de vogels zich hebben gevestigd op een bedrijventerrein, en er de wens is dat de kolonie zich verplaatst naar een nieuw aangelegd eiland in de Eems. Door de sterke fluctuaties en wisseling van vestigingen in het Eems-Dollardgebied is de trend zowel voor de hele periode als voor de laatste tien jaar onzeker. Door de wisselende ontwikkelingen in de Eemshaven en in het havengebied in Delfzijl is ook allerminst sprake van een standvastige broedpopulatie.

\section{Reproductie 2015}

In vijf kolonies werden gegevens omtrent het nestsucces verzameld, alleen op Vlieland en in de Haven van Delfzijl (twee locaties) met behulp van nestkaarten. De laatste gegevens wijzen op een nestsucces van $14,5 \%$ op de Vliehors tot $81,0 \%$ op het 'sterneiland' in de Haven van Delfzijl bij Oterdum (deze kolonie is met een elektrisch raster omgeven). Bij de twee binnendijkse kolonies op Texel waren de legsels wisselend succesvol, afgeleid van het percentage succesvolle nesten (tabel 4.5). 


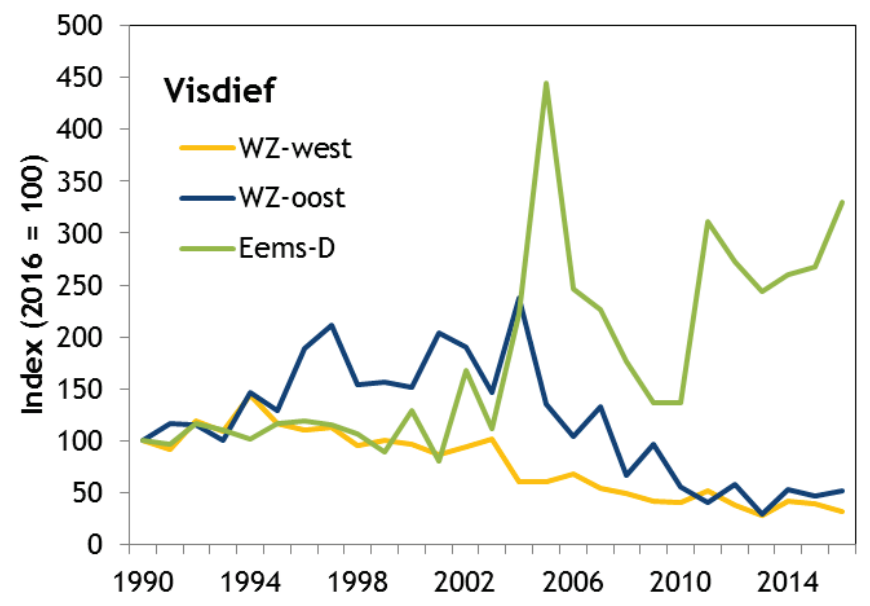

Figuur 4.17. Trends in aantallen broedparen Visdieven in de Waddenzee (index), gesplitst naar Westelijke Waddenzee (west van wantij Terschelling), oostelijke Waddenzee (tot Eemshaven) en Eems-Dollard (Eemshaven-Dollard). Gegevens broedvogelmeetnet Sovon/CBS. [Trends in numbers of breeding pairs (expressed as index) for Common Tern in the western, eastern Wadden Sea and Eems-Dollard estuary.]

In vijf van de tien kolonies (Klutenplas, Vlieland, Schiermonnikoog, De Petten en 't Stoar op Texel) kwamen in het geheel geen jongen groot. In de overige kolonies varieerde het aantal jongen per paar tussen de 0,3 en 1,0 jong per paar. Opvallend was het goede broedsucces van Visdieven op de kwelder van Hollum op Ameland (1,0 jong per paar), op de Schermdijk in de Haven van Delfzijl $(0,74)$, in de Eemshaven $(1,0)$ en op het 'sterneiland' in de Haven van Delfzijl $(0,85)$. Deze kolonies waren duidelijk succesvoller dan die op Griend, waar 0,30 jongen per paar vliegvlug werden.

\section{Reproductie 2016}

Het nestsucces in 2016 lag in alle kolonies op 50\% of lager en was dus lager dan in 2016 (tabel 4.5). In de Eemshaven viel het broedsucces relatief laag uit door grootschalige predatie door Vos in de kuikenfase. In de kolonie werden tientallen dode jongen gevonden. Alleen paren die temidden van de beschermende Kokmeeuwen broedden bleven volledig gevrijwaard van predatie door Vos. Opvallend was ook het lage succes van de kolonie bij Oterdum, waar door speciale maatregelen (grond)predatoren buiten de deur wordt gehouden (oorzaak voor lage nestsucces werd niet duidelijk). Hier speelde interactie met Kokmeeuw mogelijk een sturende rol; deze namen het grootste deel van het 'sterneiland' in beslag.

Tabel 4.5. Nestsucces van Visdief in de Waddenzee. Weergegeven zijn nestsucces cijfers op basis van Mayfield-berekeningen. Cursieve cijfers geven klassiek nestsucces weer (in vergelijking met Mayfield doorgaans een overschatting van het nestsucces). [Nest success data for Common Tern per site and per year. Given are Mayfield figures (apparent nest success given in italics).]

\begin{tabular}{|c|c|c|c|c|c|c|c|c|c|c|c|}
\hline Gebied & 2006 & 2007 & 2008 & 2009 & 2010 & 2011 & 2012 & 2013 & 2014 & 2015 & 2016 \\
\hline Texel, De Petten & & & & & & & & 0,0 & 44,0 & 80,0 & \\
\hline Texel, 't Stoar & & & & & & & & 22,0 & & 50,0 & \\
\hline Vlieland, Vliehors & & 75,0 & & 48,7 & 75,1 & & 8,2 & 67,7 & 90,7 & 14,5 & \\
\hline Griend & & 90,0 & 71,0 & 57,0 & & & & & & & \\
\hline Ameland, Oerd & & & & & 12,4 & & & & & & \\
\hline Engelsmanplaat & & & & & & 0,0 & & & & & \\
\hline Schiermonnikoog, Oosterk. & 0,0 & 0,0 & & & 6,1 & 8,9 & 4,7 & 47,0 & 60,0 & & \\
\hline Balgzand & & & & 0,0 & & & & & & & \\
\hline Noorderleech & 79,8 & & & & & & & & & & \\
\hline Kwelder Bijla & & 0,0 & & & & & & & & & \\
\hline Negenboerenpolder & 0,0 & & & & & & & & & & \\
\hline Klutenplas, Linth.Hom.pold. & & & & & & & & & & & 50,0 \\
\hline Eemshaven & & & & & & & & & & & 33,2 \\
\hline Eemshaven-enclosure & & & & & & & & & & & 48,8 \\
\hline Delfzijl, Schermpier Haven & 75,0 & & 39,4 & 48,7 & & & & & 0,1 & 41,3 & 28,4 \\
\hline Delfzijl, Haven, Ponton & & & & & 68,9 & & & 75,0 & & & \\
\hline Delfzijl, 'sterneiland' & & & & & & & & & 72,1 & 81,0 & 5,4 \\
\hline
\end{tabular}


Zes kolonies (twee binnenijks op Texel, Klutenplas, Rottumerplaat, Schiermonnikoog) mislukten (vrijwel) geheel. De andere kolonies waren duidelijk minder succesvol dan in 2015. Het broedsucces varieerde er van 0,10 (Rottumerplaat) tot 0,37 ('sterneiland' bij Oterdum) jong per paar. Op Griend bedroeg het broedsucces 0,31 jong per paar, vergelijkbaar met 2015.

\section{Ontwikkelingen sinds 2005 en discussie}

Nestgegevens werden op een groot aantal plaatsen in de Waddenzee verzameld, maar er zijn weinig reeksen van dezelfde gebieden over de hele periode. Duidelijk is dat het nestsucces enorm kan variëren van jaar tot jaar. Bij ruim een derde (36\%) van de gebied $\mathrm{x}$ jaar combinaties in tabel 4.5 bedroeg het nestsucces (onafhankelijk van de methode) meer dan 50\%. Kolonies die moeilijk toegankelijk zijn voor predatoren, zoals het tijdelijke ponton in de Haven van Delfzijl en het 'sterneiland' in het hetzelfde gebied lijken structureel succesvoller dan andere kolonies (uitgezonderd het lage nestsucces in 2016).

Het broedsucces laat sinds 1991 een significante afname zien (trend onzeker vanaf 2005) (figuur 4.18). Er is een grote mate van variatie van jaar tot jaar. Uitgaande van een drempelwaarde van 0,75 jong per paar voor een stabiele populatie is duidelijk dat Visdieven vanaf 2005 gemiddeld genomen te weinig jongen grootbrengen, al zijn er afzonderlijke kolonies die wel succesvol zijn. Mislukkingsoorzaken lijken een combinatie van verschillende factoren: predatie, overstromingen en wellicht voedselproblemen, al is dit laatste met alleen de monitoringgegevens niet te onderbouwen. Net als bij Kokmeeuw zijn visdiefkolonies op het vasteland doorgaans een kort leven beschoren vanwege het hoge predatierisico, maar daar waar kolonies minder toegankelijk zijn, of waar een elektrisch raster wordt gebruikt zijn de vogels vaak uiteindelijk wel succesvol, zodat in ieder geval voedselproblemen niet over de hele Waddenzee aan de orde hoeven te zijn. Opvallend is dat de trend in de Nederlandse Waddenzee negatiever is dan de landelijke trend, en ook negatiever in vergelijking met de Duitse en Deense Waddenzee (zie boven).
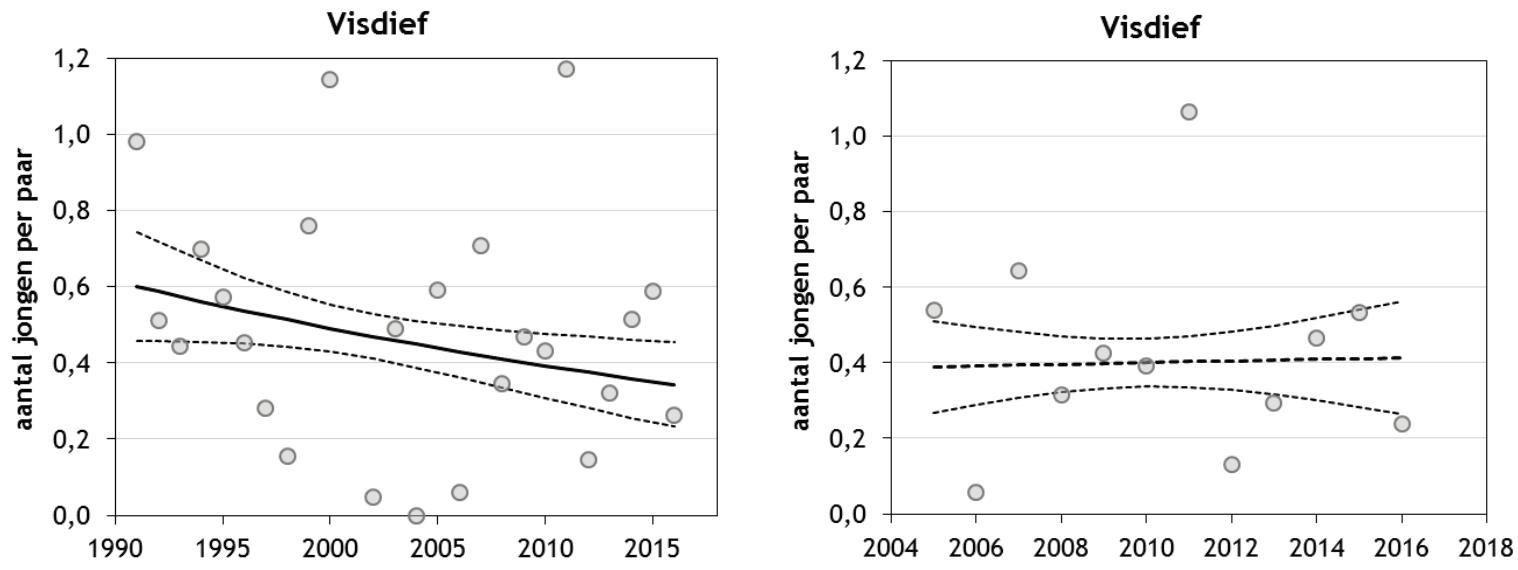

Figuur 4.18. Trend in broedsucces voor Visdief voor de periode 1991-2016 (links) en 2005-2016 (rechts). De trend in broedsucces is voor 1991-2016 negatief ( $p=0,03)$, voor 2005-2016 onzeker $(p=0,841)$. [Trend in breeding success (fledged young per pair) in Common Tern in the Dutch Wadden Sea in 1991-2016 and 2005-2016. Trend in breeding success in 1991-2016 was a significant decline; for 2005-2016 nonsignificant.]

\subsection{Noordse Stern Sterna paradisaea - Arctic Tern}

\section{Populatie en trend}

Vrijwel alle Nederlandse Noordse Sterns broeden in de Waddenzee, waar de soort ongeveer de zuidgrens van z'n broedareaal bereikt. Het aantal grotere kolonies ( $>25$ paren) is beperkt en verspreid over zowel de eilanden (Griend, Ameland, Engelsmanplaat) als langs de vaste wal (kwelder Ferwerd, Eemshaven, Punt van Reide). Het aantal broedparen nam vooral na 2000 structureel af (beneden het niveau van de instandhoudingsdoelstellingen in het Natura 2000-beheerplan voor de 
Waddenzee). Zowel op de lange termijn (vanaf 1990) als over de laatste tien jaar is de trend negatief, met uitzondering van de Eems-Dollard (toename sinds 1990, onzekere trend laatste tien jaar) (figuur 4.19). Het beeld in Nedersaksen is vergelijkbaar, maar in Sleeswijk-Holstein en Denemarken is het aantals-verloop stabiel. De fluctuaties in de Eems-Dollardregio zijn deels vergelijkbaar met die bij Visdief, en hangen samen met al dan niet tijdelijke vestigingen in de Eemshaven en het havengebied van Delfzijl.

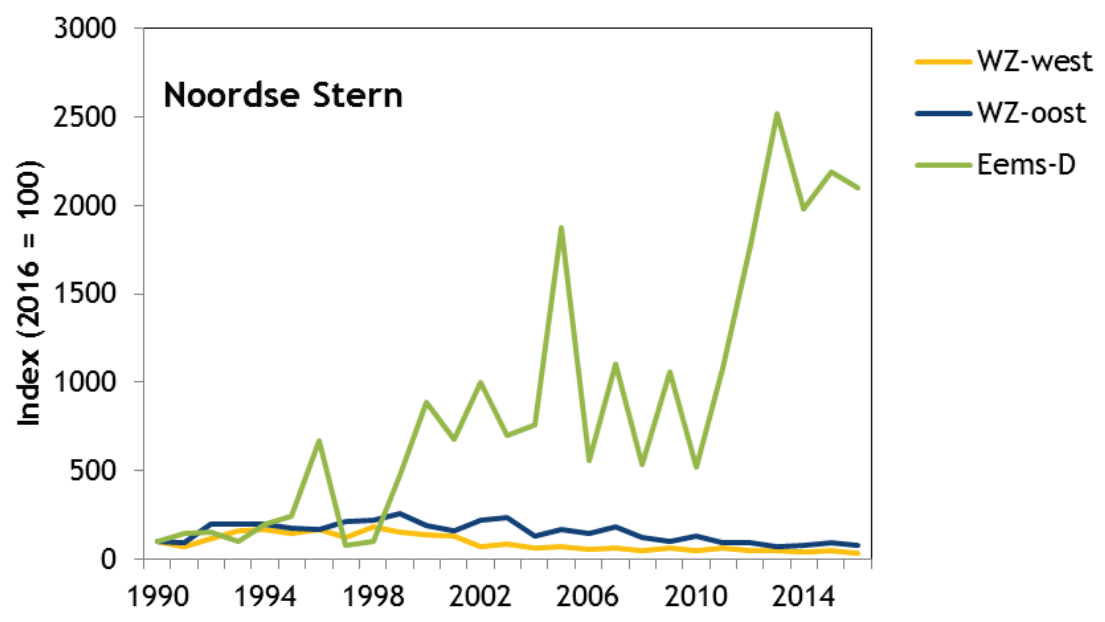

Figuur 4.19. Trends in aantallen broedparen Noordse Sterns in de Waddenzee (index), gesplitst naar Westelijke Waddenzee (west van wantij Terschelling), oostelijke Waddenzee (tot Eemshaven) en EemsDollard (Eemshaven-Dollard). Gegevens broedvogelmeetnet Sovon/CBS. [Trends in numbers of breeding pairs (expressed as index) for Arctic Tern in the western, eastern Wadden Sea and Eems-Dollard estuary.]

\section{Reproductie 2015}

Van de onderzochte nesten waren alleen die in de Eemshaven enigszins succesvol (tabel 4.6). Op de Boschplaat en op de kwelder van de Julianapolder (kleine kolonie) kwam slechts een klein deel van de legsels uit. De Vliehors op Vlieland lag daar tussen in. Predatie van eieren door o.a. Kauw speelde een belangrijke rol in het lage nestsucces.

Alleen enkele kolonies in de Eems-Dollard brachten voldoende jongen groot: die op de Punt van Reide (Dollard) met 1,0 jong per paar, en in Haven Delfzijl (kleine kolonie), eveneens met 1,0 jong per paar. In de Eemshaven was het broedsucces met 0,32 jong per paar aanzienlijk slechter dan 'stroomopwaarts' langs de Eems. De kolonie op de Punt van Reide werd met een elektrisch raster tegen predatie beschermd. Kolonies op de eilanden (Griend, Vliehors, Boschplaat/Terschelling, kwelder Hollum) mislukten (vrijwel) geheel in 2015 (0-0,07 jong per paar).

Tabel 4.6. Nestsucces van Noordse Stern in de Waddenzee. Weergegeven zijn nestsucces cijfers op basis van Mayfield-berekeningen. Cursieve cijfers geven klassiek nestsucces weer (in vergelijking met Mayfield doorgaans een overschatting van het nestsucces). [Nest success data for Arctic Tern per site and per year. Given are Mayfield figures (apparent nest success given in italics).]

\begin{tabular}{|c|c|c|c|c|c|c|c|c|c|c|c|}
\hline Gebied & 2006 & 2007 & 2008 & 2009 & 2010 & 2011 & 2012 & 2013 & 2014 & 2015 & 2016 \\
\hline Vlieland, Vliehors & & 75,0 & & 24,4 & & 0,0 & 1,5 & 32,6 & 85,8 & 40,2 & \\
\hline Terschelling, Boschplaat & & & & & & & & & & 0,0 & \\
\hline Schiermonnikoog, Oosterkw & 0,0 & & & & & & & & & & \\
\hline Noorderleech & 81,5 & & & & & & & & & & \\
\hline Julianapolder, kwelder & & & & & & & & 0,0 & & & \\
\hline Klutenplas, Linth.Hom.pold. & & & & & & & & & & 11,2 & 28,8 \\
\hline Eemshaven 1 (oostterrein) & & & & & & & & & & 73,1 & 39,9 \\
\hline Eemshaven 2 (enclosure) & & & & & & & & & & & 56,7 \\
\hline Eemshaven 3 (Wagenborg) & & & & & & & & & & & 45,9 \\
\hline Delfzijl, Schermpier Haven & & & 80,0 & & & 13,8 & 16,8 & 1,8 & 1,5 & & 0,6 \\
\hline
\end{tabular}




\section{Reproductie 2016}

Het nestsucces bedroeg in vrijwel geen enkele kolonie meer dan 50\% (alleen één van de drie kolonies in de Eemshaven komt net daarboven) (tabel 4.6). Vier van de zeven onderzochte kolonies brachten 0,1 jong per paar of minder groot, waaronder de belangrijke kolonie van Griend. In slechts drie kolonies werd meer dan 0,5 jong per paar grootgebracht (Haven Delfzijl 0,67 jong per paar, Rottumerplaat 0,50, Punt van Reide 0,53). In de Eemshaven was predatie van jongen een belangrijke mislukkingsoorzaak, met name door Torenvalk, mogelijk ook door Vos.

\section{Ontwikkelingen sinds 2005 en discussie}

De schaarse gegevens die omtrent het nestsucces werden verzameld wijzen op sterke jaarlijkse fluctuaties, zowel binnen de Waddenzee als voor afzonderlijke gebieden in opéénvolgende jaren (tabel 4.6). Voor die gebieden waar langere gegevensseries bestaan (Vlieland, Haven Delfzijl) is het nestsucces de meeste jaren laag, of zelfs bijna nul (Vlieland 2011-2012, Delfzijl 2013-2014).

Het uiteindelijke broedsucces ligt gerekend naar de jaarlijkse gewogen gemiddelden eveneens op een laag niveau (figuur 4.20). De beoogde drempelwaarde voor een op zijn minst stabiele populatie $(0,4-$ 1,0 jong per paar) wordt in vrijwel geen enkel jaar gehaald (in 2 van de 12 jarige reeks, en dan nog in het onderste deel van deze bandbreedte). De twee recente jaren 2015 en 2016 behoorden tot de slechtste in de reeks. In 2009-2012 lag het broedsucces in Sleeswijk-Holstein, met veel grotere vestigingen dan in de Nederlandse Waddenzee hoger dan in Nederland, maar eveneens te laag voor instandhouding van de populatie.

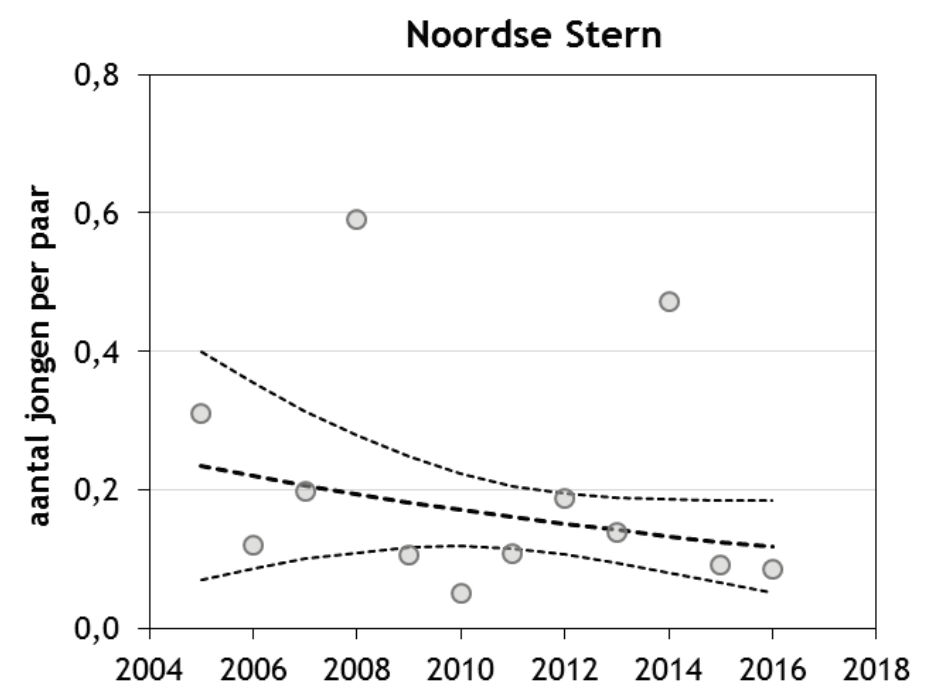

Figuur 4.20. Trend in broedsucces voor Noordse Stern voor de periode 2005-2016. De trend in broedsucces is onzeker $(p=0,238)$. [Trend in breeding success (fledged young per pair) in Arctic Tern in the Dutch Wadden Sea 2005-2016. Trend in breeding success is non-significant.] 



\section{$5 \quad$ Conclusies en discussie}

Verschillende recente rapportages hebben laten zien dat de aantallen van veel broedvogels in de Waddenzee zich in een neerwaartse spiraal bevinden (Boele et al. 2015, Koffijberg et al. 2015a), zowel internationaal als voor de Nederlandse Waddenzee afzonderlijk. In de internationale Waddenzee doen veel vogels het in het westen (Nederland, Nedersaksen) slechter dan in het oosten en noorden (Sleeswijk-Holstein en Denemarken) (Koffijberg et al. 2015a). Bovendien vertoonden sinds 1991 gaandeweg steeds meer soorten een afname (Koffijberg et al. 2016). Veel broedvogels voldoen niet aan de doelstellingen van het internationale Waddenzeeplan, of hun aantallen bevinden zich onder de geformuleerde instandhoudingsdoelstellingen voor Natura 2000. Deze negatieve resultaten contrasteren met de doorgaans positieve trends bij veel doortrekkende en overwinterende watervogels (Blew et al. 2015, Hornman et al. 2016).

Van de tien soorten die in het Meetnet Reproductie worden gemonitord, namen er sinds 1990 zeven af; alleen Lepelaar, Kleine Mantelmeeuw en Grote Stern vertoonden over deze periode een positieve trend (tabel 5.1). Voor de afgelopen tien jaar blijft dat beeld grotendeels gehandhaafd, zij het dat bij een aantal soorten de trend onzeker wordt door de combinatie van de kortere periode en jaarlijkse fluctuaties. Voor deze periode neemt alleen de Lepelaar nog toe (zij het met lagere groeisnelheid dan voor de hele periode). Kijken we naar het broedsucces voor deze soorten dan blijkt bij vier soorten er zowel sprake te zijn van een negatieve trend in aantallen (vanaf 1990) als broedresultaten die onvoldoende zijn om de populatie op peil te houden: Scholekster, Kluut, Visdief en Noordse Stern (tabel 5.1). Bij Scholekster is sprake van een 'stabiel' laag broedsucces, bij de andere drie soorten is de trend in de tijd onzeker als gevolg van sterke jaarlijkse fluctuaties. Bij Kluut waren de broedresultaten in 2015-2016 wat gunstiger dan in eerdere jaren, maar nog altijd onvoldoende om de populatie op peil te houden. Bij Visdief en Noordse Stern waren ze (ver) onder de maat. Vanaf 2011 geldt dat ook voor Kokmeeuw, die als enige soort met Lepelaar een significante afname van het broedsucces laat zien.

Tabel 5.1. Samenvatting van trends in aantallen broedparen (vanaf 1990 en vanaf 2007, classificatie volgens systematiek Sovon/CBS), het broedsucces in relatie tot het aantal vliegvlugge jongen per paar dat nodig wordt geacht voor instandhouding van de populatie (zonder rekening te houden met emigratie en immigratie) en de trend in broedsucces sinds 2005. Het broedsucces is als te laag beschouwd indien in 9 van de 12 jaar (75\% van de periode) het aantal vliegvlugge jongen per paar (gewogen gemiddelde hele Waddenzee) beneden het aantal lag dat nodig wordt geacht voor een stabiele populatie (zie Koffijberg \& Smit 2013, Thorup \& Koffijberg 2015), en als voldoende indien in 9 van de 12 jaar het aantal vliegvlugge jongen per paar boven dit aantal lag. Bij tussenliggende waarden is het broedsucces als fluctuerend beschouwd: slechtere en betere jaren wisselen elkaar af. [Overview of trends in numbers (two periods), breeding succes in relation to thresholds to maintain population size en trends in breeding success since 2005.]

\begin{tabular}{|c|c|c|c|c|}
\hline Soort & Trend aantallen $>1990$ & Trend aantallen $>2007$ & Broedsucces & Trend broedsucces $>2005$ \\
\hline Lepelaar & ++ & + & fluctuerend & matige afname \\
\hline Eider & - & $=$ & fluctuerend & onzeker \\
\hline Scholekster & - & - & te laag & stabiel \\
\hline Kluut & - & $?$ & te laag & onzeker \\
\hline Kokmeeuw & - & - & fluctuerend & sterke afname \\
\hline Kleine Mantelmeeuw & + & $=$ & fluctuerend & matige toename \\
\hline Zilvermeeuw & - & - & fluctuerend & onzeker \\
\hline Grote Stern & + & - & fluctuerend & onzeker \\
\hline Visdief & - & $?$ & te laag & onzeker \\
\hline Noordse Stern & - & - & te laag & onzeker \\
\hline
\end{tabular}

Verklaring trends in aantallen:

-- sterke afname, - matige afname, = stabiel, + matige toename, ++ sterke toename, ? trend onzeker 
Bij slechts één soort nam het broedsucces over de periode 2005-2016 significant toe, en wel bij de Kleine Mantelmeeuw. Bij deze soort stabiliseerde de eerdere populatiegroei, en afgaande op de broedresultaten in recente jaren lijkt herstel op te treden van het slechte broedsucces in de eerste vier jaren van de onderzoeksperiode (figuur 4.12).

De combinatie van negatieve trends in aantallen broedparen en magere broedresultaten bij een aantal soorten suggereert dat broedsucces een belangrijke verklaring is voor de geconstateerde afnames.

Broedsucces kan echter niet los worden gezien van de jaarlijkse overleving (of eventuele immigratie of emigratie). Van der Jeugd et al. (2014) onderzochten voor alle relevante vogelsoorten in de Waddenzee de populatiedemografie (broedsucces en overleving) en concludeerden dat bij de meeste soorten het (gebrek aan) broedsucces het sturende mechanisme was achter de negatieve aantalsveranderingen. Vooral bij soorten die (deels) van schelpdieren afhankelijk zijn, zoals Eider, Scholekster en Zilvermeeuw, speelde ook de jaarlijkse overleving een belangrijke rol. Hetzelfde geldt voor Lepelaars, waar de overleving net als broedsucces gelimiteerd wordt door dichtheidsafhankelijkheid (Lok 2013). Bij soorten met een lagere overleving (bijv. Zilvermeeuw) zou het broedsucces verhoogd moeten worden om de jaarlijkse sterfte te compenseren, maar het is maar de vraag of dat ook het geval is. Een periodiek herhaling van de analyse zoals uitgevoerd door Van der Jeugd et al. (2014) zou dan ook een goed instrument zijn om de 'gezondheidstoestand' van de broedvogels in de Waddenzee onder de loep te nemen. Een dergelijke analyse is onlangs ook uitgevoerd voor het Deltagebied (Schekkerman et al. 2017). Ook daar lijkt het broedsucces van onder andere Kluut, Kokmeeuw, Visdief en Noordse Stern te laag. Bij Kluut was bovendien sprake van een afnemende trend in broedsucces (Schekkerman et al. 2017).

Een uitgebreide analyse van de oorzaken achter de magere broedresultaten valt buiten het doel van deze rapportage. Vooral predatie, verliezen door overstromingen door stormvloeden in het broedseizoen en de voedselvoorziening lijken belangrijke factoren die het broedsucces bepalen. Deze factoren hoeven niet afzonderlijk op te treden, maar kunnen ook in afhankelijkheid van elkaar optreden (dat geldt vooral voor predatie en voedselvoorziening, Thorup \& Koffijberg 2015). Predatie vindt vooral op de broedplaatsen langs het vasteland plaats, en treft zowel steltlopers als kolonievogels. Het verlaten van grote delen van de kwelders langs de vastelandskust na 2000 moet vooral als respons op een hoge predatiekans worden gezien (Bos et al. 2015). Broedplaatsen op de eilanden, waar in ieder geval grote landpredatoren als Vos en marterachtigen ontbreken, worden daardoor nog eens extra belangrijk, maar kunnen de populaties ook kwetsbaar maken (bijv. sterke concentratie Kokmeeuw op Griend).

Gegevens omtrent het nestsucces laten zien dat het werken met elektrische rasters de kans op predatie kan verlagen (en het nestsucces verhoogt), maar een garantie dat het altijd werkt is er niet (zie bespreking Kluut en Visdief). Predatie op de eilanden komt voor (Bruine rat, grote meeuwen), maar de dimensie is veel kleiner dan op het vasteland. Overstromingen in het broedseizoen treft alle buitendijks en op geëxponeerde kwelders of strandvlakte's broedende soorten. Zoals Van de Pol et al. (2010) hebben laten zien treedt dit fenomeen in de afgelopen decennia vaker op, en is voor enkele soorten die langs de randen van het wad broeden een belangrijke bottleneck.

Voedselproblemen zijn veel minder zichtbaar dan gepredeerde of weggespoelde nesten, en dus niet goed te kwantificeren. Dit aspect verdient dan ook nader onderzoek. Bij een aantal kolonievogels liggen voedselproblemen voor de hand (bijv. Kleine Mantelmeeuw, Zilvermeeuw, Grote Stern, Visdief, Noordse Stern), maar de schaal en aard waarop dit speelt is met alleen monitoringcijfers moeilijk te beantwoorden. Visdief en Noordse Sterns doen het in sommige jaren goed in het Eems-Dollardgebied (Eemshaven en haven Delfzijl), maar juist daar is er grote onzekerheid over de locaties waar de vogels succesvol kunnen broeden. Ook een soort als Kluut kampt mogelijk met voedselproblemen: op plaatsen waar nesten succesvol zijn, blijkt het uiteindelijke broedsucces erg laag. Dit geldt zeker voor binnendijkse broedplaatsen als de Klutenplas, waar de paren met jongen direct na uitkomen van het legsel zich verplaatsen naar de kwelder (De Boer 2015, 2016). Effecten van slecht weer en predatie lijken bij deze soort niet op grote schaal op te treden (dat wil zeggen niet elk jaar en/of in alle gebieden), zodat de voedselvoorziening in de kuikenperiode in beeld komt als mogelijk beperkende factor. Nader onderzoek bij deze soort is ook extra gewenst in de context van het grote verschil tussen de actuele aantallen broedparen en de geformuleerde instandhoudingsdoelstelling voor het Natura 2000-gebied Waddenzee. 


\section{Literatuur}

Beintema A.J. (1992). Mayfield moet: oefeningen in het berekenen van uitkomstsucces. Limosa 65: 155162.

Blew J., Günther K., Hälterlein B., Kleefstra R., Laursen K.\& Scheiffarth G. (2015). Trends of Migratory and Wintering Waterbirds in the Wadden Sea 1987/1988 - 2011/2012. Wadden Sea Ecosystem No. 34. Common Wadden Sea Secretariat, Joint Monitoring Group of Migratory Birds in the Wadden Sea, Wilhelmshaven, Germany.

Boele A., van Bruggen J., Hustings F., Koffijberg K., Vergeer J.-W. \& van der Meij T. (2016). Broedvogels in Nederland in 2014. Sovon-monitoringrapport 2016/04. Sovon Vogelonderzoek Nederland, Nijmegen.

de Boer P. (2015). Broedvogels van de Klutenplas in 2015. aantallen en broedsucces. Sovonrapport 2015/63. Sovon Vogelonderzoek Nederland, Nijmegen.

de Boer P. (2016). Broedvogels van de Klutenplas in 2016. aantallen en broedsucces. Sovonrapport 2016/48. Sovon Vogelonderzoek Nederland, Nijmegen.

de Boer P., Oosterbeek K., Koffijberg K., Ens B., Smit C. \& de Jong M. (2007). Broedsucces van kustbroedvogels in de Waddenzee in 2006. SOVON-monitoringrapport 2007/03, IMARES-rapport C036/08. SOVON Vogelonderzoek Nederland/IMARES, Beek-Ubbergen/Den Burg.

Bos D., Engelmoer M., Feddema J. \& Koffijberg K. (2015). Broedvogels van Noord-Friesland Buitendijks en de invloed van verkweldering op hun aantallen. Limosa 88: 31-42.

Camphuysen C.J. (2013). A historical ecology of two closely related gull species (Laridae): multiple adaptations to a man-made environment. Proefschrift, Rijksuniversiteit Groningen, Groningen.

Camphuysen C.J., Berrevoets C.M., Cremers H.J.W.M., Dekinga A., Dekker R., Ens B.J., van der Have T.M., Kats R.K.H., Kuiken T., Leopold M.F., van der Meer J. \& Piersma T. (2002.) Mass mortality of common eiders (Somateria mollissima) in the Dutch Wadden Sea, winter 1999/2000: starvation in a commercially exploited wetland of international importance. Biological Conservation 106: 303-317.

CBS (2013). Kwaliteitsrapportage Netwerk Ecologische Monitoring. CBS, Den Haag.

Cook A.S., Dadam D., Mitchell I., Ross-Smith V.H., Robinson R.A. (2014). Indicators of seabird reproductive performance demonstrate the impace of commercial fisheries on seabird populations in the North Sea. Ecological indicators 38: 1-11.

Hornman M., Hustings F., Kofifjberg K., Klaassen O., van Winden E., Sovon Ganzen- en Zwanenwerkgroep \& Soldaat L. (2016). Watervogels in Nederland in 2014/15. Sovon-rapport 2016/54. RWS-rapport BM16.15. Sovon Vogelonderzoek Nederland, Nijmegen.

van der Jeugd H.P, Ens B.J., Versluijs M. \& Schekkerman H. (2014). Geïntegreerde monitoring van vogels van de Nederlandse Waddenzee. Vogeltrekstation rapport 2014-01. Vogeltrekstation, Wageningen; CAPSrapport 2014-01; Sovon-rapport 2014/18, Sovon Vogelonderzoek Nederland, Nijmegen.

Kats R.K.H. (2007). Common Eiders Somateria mollissima in the Netherlands: The rise and fall of breeding and wintering populations in relation to the stocks of shellfish. PhD-thesis, Universiteit of Groningen.

van Kleunen A., Koffijberg K., de Boer P., Nienhuis J., Camphuysen C.J., Schekkerman H., Oosterbeek K., de Jong M., Ens B. \& Smit C. (2010). Broedsucces van kustbroedvogels in de Waddenzee in 2007 en 2008. Sovon-monitoringrapport 2010/04, IMARES-rapport C169/10. Sovon Vogelonderzoek Nederland, Nijmegen, IMARES, Texel. WOt-werkdocument 227, WOT Natuur \& Milieu, Wageningen.

van Kleunen A., de Boer P., Koffijberg K., Oosterbeek K. Nienhuis J., de Jong M.L., Smit C.J. \& van Roomen M. (2012). Broedsucces van kustbroedvogels in de Waddenzee in 2009 en 2010. WOt-werkdocument 346. WOT Natuur \& Milieu, WUR, Wageningen.

Koffijberg K. \& Smit C. (2013). Broedsucces van kenmerkende kustbroedvogels in de Waddenzee in mineur. WOt paper 25. Wettelijke Onderzoekstaken Natuur \& Milieu, Wageningen.

Koffijberg K., Schrader S. \& Hennig, V. (2011). TMAP Manual breeding success, 2nd version 2011. Common Wadden Sea Secretariat, Wilhelmshaven. 
Koffijberg K., Laursen K., Hälterlein B., Reichert G., Frikke J. \& Soldaat L. (2015a). Progres report trends of breeding birds in the Wadden Sea 1991-2013. Wadden Sea Ecosystem 35. Common Wadden Sea Secretariat, Trilateral Monitoring and Assessment Group, Joint Monitoring Group of Breeding Birds in the Wadden Sea, Wilhelmshaven.

Koffijberg K., de Boer P., Hustings F., van Kleunen A., Oosterbeek K. \& Cremer J. (2015b). Broedsucces van kustbroedvogels in de Waddenzee in 2011-2013. Sovon-rapport 2015/61, IMARES-rapport C153/15., WOt-technical report 51. Sovon Vogelonderzoek Nederland, Nijmegen, IMARES, Den Helder \& WOT Natuur \& Milieu, WUR, Wageningen.

Koffijberg K., Cremer J, de Boer, P., Postma J. \& Oosterbeek K. (2016a). Broedsucces van kustbroedvogels in de Waddenzee in 2014. WOt-technical report 78 / Sovon-rapport 2016/11 / Wageningen Marine Research-rapport C112/16. WOT Natuur \& Milieu - WUR, Wageningen /Sovon Vogelonderzoek Nederland, Nijmegen / Wageningen Marine Research, Den Helder.

Koffijberg K., Frikke J., Hälterlein B., Reichert G. \& Andretzke H. (2016b). Breeding birds in trouble: a framework for an action plan in the Wadden Sea. CWSS, Wilhelmshaven

Lok T. (2013). Spoonbills as a model system: a demographic cost-benefit analysis of differential migration. Proefschrift, Rijksuniversiteit Groningen, Groningen.

Lok T., Overdijk O., Horn H. \& Piersma T. (2009). De lepelaarpopulatie van de Wadden. Komt het einde van de groei in zicht? Limosa 82: 149-157.

Lok T., Overdijk O., Tinbergen J.M. \& Piersma T. (2013). Seasonal variation in density dependence in agespecific survival of a long-distance migrant. Ecology 94: 2358-2369.

Lutterop D. \& Kasemir G. (2016). Griend Broedvogels en Bewaking 2015. Rapport Vereniging Natuurmonumenten, 's-Graveland.

Lutterop D. \& Kasemir G. (2017). Griend Broedvogels en Bewaking 2016. Rapport Vereniging Natuurmonumenten, 's-Graveland.

Oosterhuis R., Dijksen L.J., Ens B.J., Foppen R., de Jong M., Kats, R.K.H., Koks B.J., van Turnhout C. \& Willems F. (2004). Naar een reproductiemeetnet voor broedvogels in de Waddenzee. Alterra-rapport 944 / SOVON-onderzoeksrapport 2004/03. Alterra/SOVON Vogelonderzoek Nederland, Wageningen/BeekUbbergen.

Oudman T., de Goeij P., Piersma T. \& Lok T. (2017). Colony-breeding Eurasian Spoonbills in The Netherlands: local limits to population growth with expansion into new areas. Ardea 105, doi:10.5253/arde.v105i2.a2.

van de Pol M., Ens B.J., Heg D., Brouwer L., Krol J., Maier M., Exo K-M., Oosterbeek K., Lok T., Eising C.M. \& Koffijberg, K. (2010). Do changes in the frequency, magnitude and timing of extreme climatic events threaten the population viability of coastal birds? Journal of Applied Ecology 47: 720-730.

Reneerkens J., Piersma T., Spaans B. (2005). De Waddenzee als kruispunt van vogeltrekwegen. Literatuurstudie naar de kansen en bedreigingen van wadvogels in internationaal perspectief. NIOZreport 2005-4, Texel.

Schekkerman H., Arts F.A., van der Jeugd H., Stienen E.W.M. \& van Roomen M. (2017). Naar een demografische analyse van populaties van karakteristieke vogels in het Deltagebied. Sovon-rapport 2017/58, CAPS-rapport 2017/01. Sovon Vogelonderzoek Nederland/Vogeltrekstation/Delta Project Management/Instituut voor Natuur en Bosonderzoek, Nijmegen.

Thorup O. \& Koffijberg K. (2015). Breeding success in the Wadden Sea in 2009-2012: a review. Wadden Sea Ecosystem 36. Common Wadden Sea Secretariat, Wilhelmshaven.

van Turnhout C. (2008). Nestkaartenproject gaat 14e jaar in. SOVON-Nieuws 21 (1) 11-12.

Willems F., Oosterhuis R., Dijksen L., Kats R. \& Ens B. (2005). Broedsucces van kustbroedvogels in de Waddenzee 2005. SOVON-onderzoeksrapport 2005/07 / Alterra-rapport 1265. SOVON Vogelonderzoek Nederland, Beek-Ubbergen / Alterra, Texel. 


\section{Verantwoording en dankwoord}

Het project Reproductiemeetnet kustbroedvogels is onderdeel van de WOT Natuur en milieu, thema Informatievoorziening Natuur, en wordt uitgevoerd in opdracht van het ministerie van Landbouw, Natuur en Voedselkwaliteit (LNV). Contactpersoon bij LNV voor de projecten die onder de Informatievoorziening Natuur vallen is Bernard Baerends. Contactpersoon bij de WOT Natuur \& Milieu is Anne Schmidt van Wageningen Environmental Research.

Het rapport is binnen Wageningen Marine Research (WMR) beoordeeld door dr. G. Aarts (onderzoeker) en Drs. J. Asjes (manager integratie). Hun review heeft geleid tot verbeteringen van het rapport.

\section{Dankwoord}

Uitvoering van het Meetnet Reproductie in de Waddenzee is alleen mogelijk dankzij de bereidwillige medewerking van de terreinbeheerders en een groot aantal vrijwilligers. In 2015-2016 ging het om de volgende personen en organisaties:

\section{Texel:}

Kees Camphuysen (NIOZ), Bernard Spaans, Marc Plomp en Giel Witte (VWG Texel), Dick Schermer, Rob Sier en Jitske Esselaar (allen Staatsbosbeheer), Martin de Jong (Noordkop Groen), Jenny Cremer en Cor Smit (IMARES, tegenwoordig Wageningen Marine Research), Lieuwe Dijksen (Sovon/VWG Texel), Eric Menkveld (Natuurmonumenten) en Bob Loos (VWG Texel).

\section{Vlieland:}

Peter de Boer (Sovon), Carl Zuhorn (Staatsbosbeheer Regio Noord), Petra de Goeij (Rijksuniversiteit Groningen/NIOZ/Metawad).

\section{Terschelling:}

Arjan Zonderland, Arjan de Jong, Leo Bot, Freek Zwart (allen Staatsbosbeheer Regio Noord), Peter de Boer en Lieuwe Dijksen (Sovon).

\section{Ameland:}

Ricus Engelmoer, Jan de Jong, Frits Oud en Richard Kiewiet (It Fryske Gea), Jeffrey Huizenga (Staatsbosbeheer), Jelle Postma en Kees Oosterbeek (beide Sovon).

\section{Schiermonnikoog:}

Kees Oosterbeek, Romke Kleefstra \& Symen Deuzeman (Sovon), Petra de Goeij (Rijksuniversiteit Groningen/NIOZ/Metawad), Erik Jansen (Natuurmonumenten).

\section{Rottumerplaat:}

Bart Ebbinge, Doortje Ebbinge-Dallmeijer, Nelly van Brederode en Hans Roersma, Sjoerd Dirksen, Hella Smit, Harry Horn, Ron Mes, Ellen Pont - allen vogelwachters Staatsbosbeheer Regio Noord. Bert Corté, Jaap Kloosterhuis en Jasper Schut (allen Staatsbosbeheer Regio Noord).

\section{Rottumeroog \& Zuiderduin:}

Nico de Vries, Bert Corté, Jaap Kloosterhuis en Jasper Schut (Staatsbosbeheer Regio Noord).

\section{Griend:}

Date Lutterop \& Giny Kasemir, Erik Jansen (Natuurmonumenten).

\section{Noord-Hollandse kust:}

Roelf Hovinga (Landschap Noord-Holland), Lieuwe Dijksen (Sovon). 


\section{Groninger kust en Dollard:}

Derick Hiemstra (Avifauna Groningen), Peter de Boer en Romke Kleefstra (beide Sovon), Arjan Hendriks, Silvan Puijman en Dirk Brul (allen Stichting Het Groninger Landschap), Kees Koffijberg (Avifauna Groningen/Sovon), Allix Brenninkmeijer (Altenburg \& Wymenga) en Maarten Loonen (Arctisch Centrum, Rijksuniversiteit Groningen).

De schippers van MS Harder Klaas Kreuijer, Freek-Jan de Wal en Jan Kostwinner (Waddenunit, Ministerie van EZ) willen we hartelijk danken voor de logistiek voor de bewakers van Rottumeroog en Rottumerplaat en de tocht naar De Hond.

Alle terreinbeheerders, Staatsbosbeheer, Natuurmonumenten, Het Noord-Hollands Landschap, It Fryske Gea en Het Groninger Landschap en Groningen Seaports worden bedankt voor het verlenen van toestemming om in hun terreinen gegevens te verzamelen.

Adriaan Gmelig-Meyling en Tom van der Meij (CBS) verzorgden de berekening van de trends in aantallen broedparen in het kader van het Netwerk Ecologische Monitoring. 


\section{Verschenen documenten in de reeks Technical reports van de Wettelijke Onderzoekstaken Natuur}

\& Milieu vanaf 2016

WOt-technical reports zijn verkrijgbaar bij het secretariaat van Unit Wettelijke Onderzoekstaken Natuur \& Milieu te Wageningen. T 0317 - 4854 71; E info.wnm@wur.nl

\section{WOt-technical reports zijn ook te downloaden via de website www.wur.nl/wotnatuurenmilieu}

61 Berg, F. van den, A. Tiktak, J.J.T.I. Boesten \& A.M.A. van der Linden (2016). PEARL model for pesticide behaviour and emissions in soil-plant systems; Description of processes

62 Kuiters, A.T., G.A. de Groot, D.R. Lammertsma, H.A.H. Jansman \& J. Bovenschen (2016). Genetische monitoring van de Nederlandse otterpopulatie; Ontwikkeling van populatieomvang en genetische status 2014/2015

63 Smits, M.J.W., C.M. van der Heide, H. Dagevos, T. Selnes \& C.M. Goossen (2016). Natuurinclusief ondernemen: van koplopers naar mainstreaming?

64 Pouwels, P. , M. van Eupen, M.H.C. van Adrichem, B. de Knegt \& J.G.M. van der Greft (2016).

MetaNatuurplanner v2.0. Status A

65 Broekmeyer, M.E.A. \& M.E. Sanders (2016). Natuurwetgeving en het omgevingsrecht. Achtergrond-document bij Balans van de Leefomgeving, 2014

66 Os, J. van, J. H.S.D. Naeff \& L.J.J. Jeurissen (2016).Geografisch informatiesysteem voor de emissieregistratie van landbouwbedrijven; GIABplusbestand 2013 - Status A

67 Ingram, V.J., L.O. Judge, M. Luskova, S. van Berkum \& J. van den Berg (2016). Upscaling sustainability initiatives in international commodity chains; Examples from cocoa, coffee and soy value chains in the Netherlands.

68 Duin van W.E., H. Jongerius, A. Nicolai, J.J. Jongsma, A. Hendriks \& C. Sonneveld (2016). Friese en Groninger kwelderwerken: Monitoring en beheer 1960-2014.

69 Ehlert, P.A.I., T.A. van Dijk \& O. Oenema (2016). Opname van struviet als categorie in het Uitvoeringsbes/uit Meststoffenwet. Advies.

70 Ehlert, P.A.I., H.J. van Wijnen, J. Struijs, T.A. van Dijk, L. van Schöll, L.R.M. de Poorter (2016). Risicobeoordeling van contaminanten in afval- en reststoffen bestemd voor gebruik als covergistingsmateriaal

71 Commissie Deskundigen Meststoffenwet (2016). Protocol beoordeling stoffen Meststoffenwet. Versie 3.2

72 Kramer, H., J. Clement (2016). Basiskaart Natuur 2009. Een landsdekkend basisbestand voor de terrestrische natuur in Nederland

73 Dam, R.I. van, T.J.M. Mattijssen, J. Vader, A.E. Buijs \& J.L.M. Donders (2016). De betekenis van groene zelf-governance. Analyse van verschillende vormen van dynamiek in de praktijk.
74 Hennekens, S.M., M. Boss \& A.M. Schmidt (2016). Landelijke Vegetatie Databank; Technische documentatie, Status A

75 Knegt, B. de, et al. (2016). Kansenkaarten voor duurzaam benutten van Natuurlijk Kapitaal

76 Commissie Deskundigen Meststoffenwet (2016). Advies 'Mestverwerkingspercentages 2017'

77 W.H.J. Beltman, C. Vink \& A. Poot (2016). Calculation of exposure concentrations for NL standard scenarios by the TOXSWA model; Use of FOCUS_TOXSWA 4.4.3 software for plant protection products and their metabolites in Dutch risk assessment for aquatic ecosystems

78 Koffijberg K., J.S.M. Cremer, P. de Boer, J. Postma \& K. Oosterbeek \& J.S.M. Cremer (2016). Broedsucces van kustbroedvogels in de Waddenzee in 2014.

79 Sanders, M.E. G.W.W Wamelink, R.M.A. Wegman \& J. Clement (2016). Voortgang realisatie nationaal natuurbeleid; Technische achtergronden van een aantal indicatoren uit de digitale Balans van de Leefomgeving 2016.

80 Vries, S. de \& I.G. Staritsky (2016). AVANAR 2.0 nader beschreven en toegelicht; Achtergronddocumentatie voor Status $A$.

81 Kuiters, A.T., G.A. de Groot, D.R. Lammertsma, H.A.H. Jansman \& J. Bovenschen (2016). Genetische monitoring van de Nederlandse otterpopulatie Ontwikkeling van populatieomvang en genetische status 2015/ 2016.

82 Pleijte, M., R. Beunen \& R. During (2016). Rijksprojecten: hét natuurinclusieve werken? Een analyse van relaties tussen rijksprojecten en de Rijksnatuurvisie

83 Smits, M.J.W. en E.J. Bos (2016). Het stimuleren van ondernemen met natuur: handelingsopties voor de overheid

84 Horst, M.M.S. ter, W.H.J. Beltman \& F. van den Berg (2016). The TOXSWA model version 3.3 for pesticide behaviour in small surface waters; Description of processes

85 Mattijssen, T.J.M. (2016). Ideaaltypen en analysekader van groene burgerinitiatieven; Bijlage bij het rapport 'De betekenis van groene burgerinitiatieven: analyse van kenmerken en effecten van 264 initiatieven in Nederland

86 Wösten, J.H.M., F. de Vries \& J.G. Wesseling (2016). BOFEK2012 versie 2; Status $A$

87 Pleijte, M., R. During \& R. Michels (2016). Nationale parken in transitie; governance-implicaties van een veranderend beleidskader 
88 Mol-Dijkstra, J.P.\& G.J Reinds (2017). Technical documentation of the soil model VSD+; Status A

89 Arets, E.J.M.M., J.W.H van der Kolk, G.M. Hengeveld, J.P. Lesschen, H. Kramer, P.J. Kuikman \& M.J. Schelhaas (2017). Greenhouse gas reporting for the LULUCF sector in the Netherlands. Methodological background, update 2016

90 Bruggen, C. van, A. Bannink, C.M. Groenestein, J.F.M. Huijsmans, H.H. Luesink, S.V. Oude Voshaar, S.M. van der Sluis, G.L. Velthof \& J. Vonk (2017). Emissies naar lucht uit de landbouw in 2014. Berekeningen met het model NEMA

91 Os van, J., M.G.T.M. Bartholomeus, L.J.J. Jeurissen \& C.G. van Reenen (2017). Rekenregels rundvee voor de landbouwtelling. Verantwoording van het gebruik van I\&R gegevens voor de landbouwtelling

92 Haas, W. de, R.J. Fontein \& M. Pleijte (2017). Is eenvoudig beter? Twee essays natuur en landschap in het nieuwe omgevingsbeleid

93 Schuiling, C., A.M. Schmidt, I.J. La Rivière \& R.A. Smidt (2017). Beschermde gebiedenregister; Technische documentatie, Status $A$.

94 Henkens, R.J.H.G., M.M.P. van Oorschot en J. Ganzevles (2017). Bijdrage van Green Deals aan de beleidsdoelen voor natuur en biodiversiteit

95 Arets, E.J.M.M., J.W.H van der Kolk, G.M. Hengeveld, J.P. Lesschen, H. Kramer, P.J. Kuikman \& M.J. Schelhaas (2017). Greenhouse gas reporting for the LULUCF sector in the Netherlands. Methodological background, update 2017

96 IJsseldijk, L.L., M.J.L. Kik, L. Solé \& A. Gröne (2017) Postmortaal onderzoek van bruinvissen (Phocoena phocoena) uit Nederlandse wateren, 2016.

97 Verburg, R.W., W.H.G.J. Hennen, L.F. Puister, R. Michels \& K. van Duijvendijk (2017). Estimating costs of nature management in the European Union; Exploration modelling for PBL's Nature Outlook

98 Bruggen, C. van, A. Bannink, C.M. Groenestein, J.F.M. Huijsmans, H.H. Luesink, S.V. Oude Voshaar, S.M. van der Sluis, G.L. Velthof \& J. Vonk (2017). Emissies naar lucht uit de landbouw in 2015. Berekeningen met het model NEMA

99 Kuiters, A.T., G.A. de Groot, D.R. Lammertsma, H.A.H. Jansman \& J. Bovenschen (2017). Genetische monitoring van de Nederlandse otterpopulatie; Ontwikkeling van populatieomvang en genetische status 2016/2017

100 Adriaanse, P.I. \& W.H.J Beltman (2017) Comparison of pesticide concentrations at drinking water abstraction points in The Netherlands simulated by DROPLET version 1.2 and 1.3.2.

101 Daamen, W.P., A.P.P.M. Clerkx \& M.J. Schelhaas (2017). Veldinstructie Zevende Nederlandse Bosinventarisatie (2017-2021)

102 Boer, T.A. de \& F.L. Langers (2017). Maatschappelijk draagvlak voor natuurbeleid en betrokkenheid bij natuur in 2017
103 Buijs, A.E., B.H.M. Elands \& C.S.A. van Koppen (2017) Vijfentwintig jaar burgerbetrokkenheid in het natuurbeleid. Analyse van beleidsdiscoursen en publiek draagvlak

104 Cremer, J.S.M., S.M.J.M. Brasseur., A. Meijboom, J. Schop \& J.P. Verdaat (2017). Monitoring van gewone en grijze zeehonden in de Nederlandse Waddenzee, 2002-2017

105 Glorius, S.T., A. Meijboom, J.T. van der Wal \& J.S.M. Cremer (2017). Ontwikkeling van enkele mosselbanken in de Nederlandse Waddenzee, situatie 2016

106 Hennekens, S.M., W.A. Ozinga \& J.H.J. Schaminée (2017). BioScore 3 - Plants. Background and preprocessing of distribution data

107 Melman, Th.C.P., M.H.C. van Adrichem, M. Broekmeyer, J. Clement, R. Jochem, H.A.M. Meeuwsen, F.G.W.A. Ottburg, A.G.M. Schotman \& T. Visser (2017). Bijdrage natuurcombinaties aan landelijke natuurdoelstelling buiten NNN; Verkenning van een methodiek, gebaseerd op ecologische modellen

109 Overbeek, M.M.M., E. Smeets \& D. Verhoog (2017). Biobased materialen, circulaire economie en natuurlijk kapitaal

110 Pouwels, R., G.W.W. Wamelink, M.H.C. van Adrichem, R. Jochem, R.M.A. Wegman en B. de Knegt. (2017). MNP v4.0 Status A; toepassing voor Evaluatie Natuurpact

111 Commissie Deskundigen Meststoffenwet (2017). Advies Mestverwerkingspercentages 2018

112 Koffijberg K., J.S.M. Cremer, P. de Boer, J. Nienhuis, H. Schekkerman, J. Postma \& K. Oosterbeek (2017). Broedsucces van kustbroedvogels in de Waddenzee. Resultaten 2015-2016 en trends in broedsucces in 2005-2016 



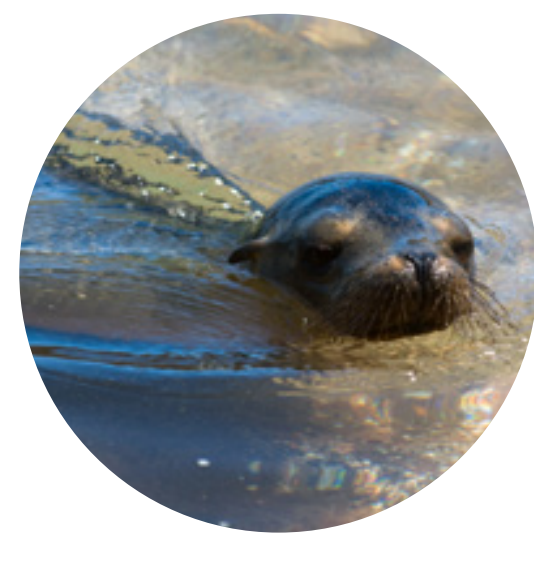

Thema Informatievoorziening Natuur Wettelijke Onderzoekstaken Natuur \& Milieu

Postbus 47

6700 AA Wageningen

T (0317) 485471

E info.wnm@wur.nl

ISSN 2352-2739

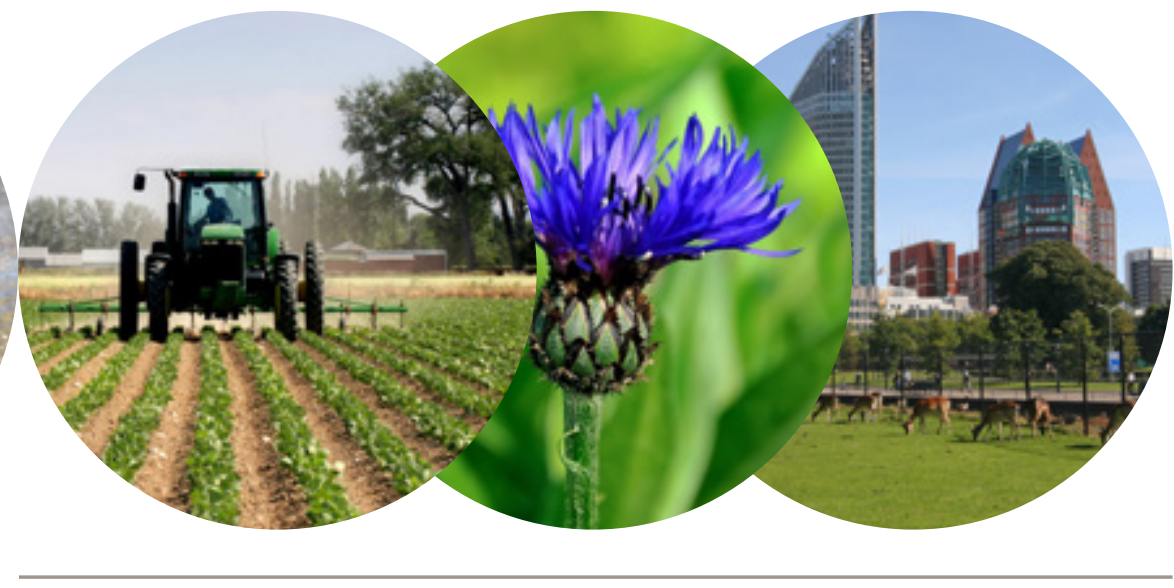

De missie van Wageningen University \& Research is 'To explore the potential of nature to improve the quality of life'. Binnen Wageningen University \& Research bundelen 9 gespecialiseerde onderzoeksinstituten van Stichting Wageningen Research en Wageningen University hun krachten om bij te dragen aan de oplossing van belangrijke vragen in het domein van gezonde voeding en leefomgeving. Met ongeveer 30 vestigingen, 5.000 medewerkers en 10.000 studenten behoort Wageningen University \& Research wereldwijd tot de aansprekende kennisinstellingen binnen haar domein. De integrale benadering van de vraagstukken en de samenwerking tussen verschillende disciplines vormen het hart van de unieke Wageningen aanpak. 